


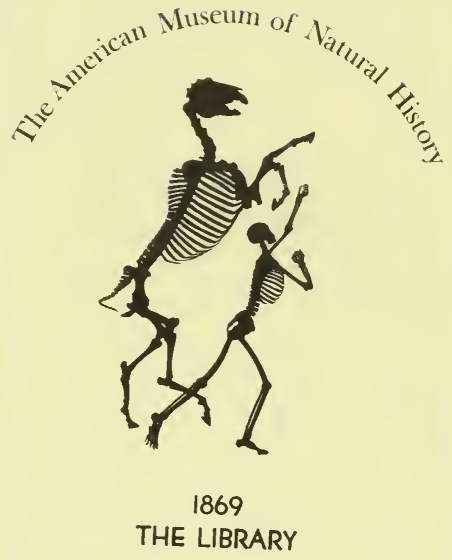










OUR FAVOURITE SONG BIRDS 

THE PAES LA THIS VOLUME MUV

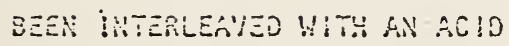
:

FREE PAPER TO PERYIT SHUSU ANO TO REDUCE FURTHER OETER!W Q⿻土一⺝ 0.5 



\title{
OUR FAVOURITE SONG BIRDS
}

Their Habits, Music, and Characteristics

\author{
EY \\ CHARLES DIXON \\ AUTHOR OF "RURAL BIRD-LIFE," "THE BIRDS OF OUR KAMBLES," \\ “ANNALS OF BIRD-LIFE," "IDLE hOURS WITH NATURE," \\ "THE MIGRATION OF BIRDS," ETC.
}

※uitb Fllustrations of every \$pecies, by ד. Itannard

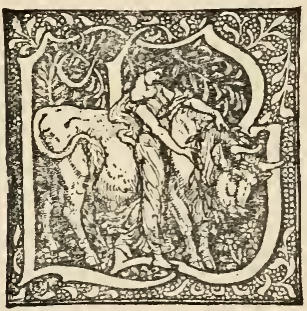

LONDON

LAWRENCE AND BULLEN, LTD.

16, HENRIETTA STREET, COVENT GARDEN, W.C.

I 897

A.l rights reserved 
.80 .0710 nnock 




\section{PREFACE}

THE ever-increasing interest which birds excite, the ever-widening circle of students and admirers they continue to attract, is most eloquent testimony to the exceptional charm of Ornithology as a science. Of all wild creatures Birds are incomparably the popular favourites. Their engaging ways, their comings and their goings at appointed times and seasons, their gay colours, their beautiful nests and pretty eggs, their domestic affections and ties, and above all their wonderful music, attract the least sentimental among us, arouse our sympathies, and charm the majority of us to a degree unapproached by any other living forms.

The music of the fields and woodlands is one of the most gratifying pleasures of the country. The variety of these songs is great, their beauty a refreshing and perennial one. But vast numbers of people to whom the songs of birds are a constant source of delight, know very few of these singers by name; 
they are at a loss to identify them, although familiar enough with many of their songs, and are practically ignorant of their habits and economy.

The present volume has been written to furnish just the popular information respecting our favourite song birds that the less informed average observer would like to acquire. It is neither an ambitious nor a scientific treatise, but a simple guide to the characteristics, the songs, and the habits of those common birds of ours whose voices at one season of the year or another gladden almost every country stroll. That it may prove a pleasant and informing companion to these rambles is the hearty wish of its author, who has used every endeavour to make it so.

C. D.

Paignton, Devon, 1897. 




\section{CONTENTS}

PAGE

INTRODUCTION

I

T.1E WARBLERS

THE WARBLERS

THE BLACKCAP WARBLER (Sylvia atricapilla) ...

... 2 I

THE GARUEN WARBLER (Syliza hortensis)

... 26

THE COMMON WHITETHROAT (Sylvia cinerea)

... 32

THE LESSER WHITETHROAT (Syliza curruca)

... 38

THE WILLOW WARBLER (Phylloscopus trochilus) ... $\quad \ldots \quad 49$

THE GOLDCREST (Regulus cristatus) $\quad \ldots \quad \quad \ldots \quad \ldots \quad \ldots \quad 55$

THE SEDGE WARBLER (Acro,ephalus phrasmitis) $\quad \ldots \quad 61$

THE REED WARBLER (Acrocephalus streperus) $\quad \ldots \quad \ldots \quad \ldots 6$

THE GRASSHOPPER WARBLER (Locustella nazia) ... $\quad \ldots \quad 74$

\section{THE THRUSHES}

THE THRUSHES

THE NIGHTINGALE (Erithacus luscinia)

THE ROBIN (Erithacus rubecula)

THE HEDGE ACCENTOR (Accentor modularis)

THE SONG THRUSH (Turdus musicus) ...

THE MISTLE-THRUSH (Turdus viscivorus)

THE BLACKBIRD (Merula vulgaris) ...

THE RING OUZEL (Merula torquata) ...

$\begin{array}{rrr}\ldots & \ldots & 83 \\ \ldots & \ldots & 88 \\ \ldots & \ldots & 94 \\ \ldots & \ldots & 100 \\ \ldots & \ldots & 106 \\ \ldots & \ldots & 112 \\ \ldots & \ldots & 118 \\ \ldots & \ldots & 123\end{array}$

\section{THE DIPPERS AND WRENS}

THE DIPPERS AND WRENS

THE DIPPER (Cinclus aquaticus)

THE COMMON wREN (Troglodytes parrulus)
... I $3^{1}$

... I 34

... I 40 
THE PIPITS

THE PIPITS

THE TREE PIPIT (Anthus trivialis) $\ldots$

THE MEADOW PIPIT (Anthus pratensis)

THE ROCK PIPIT (Anthus obscurus) ...

PAGE

147

I44)

... I 55

... I6 I

\section{THE LARKS}

THE LARKS

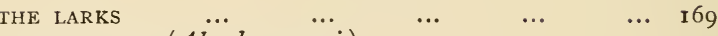

THE SKY-LARK (Alauda arvensis) $\quad \ldots \quad \ldots \quad \ldots \quad \ldots \quad$ I72

THE WOOD-LARK $($ Alauda arborea) $\quad \ldots \quad \ldots \quad \ldots \quad$ I 78

THE BUNTINGS

THE BUNTINGS

THE YELLOW BUNTING (Emberiza citrinella)

THE CIRL BUNTING (Emberiza cirlus) ...

THE REED BUNTING (Emberiza schaniclus)

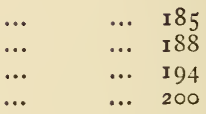

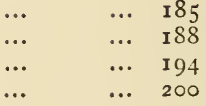

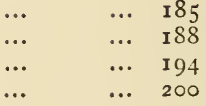

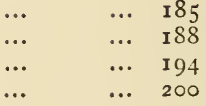

\section{THE FINCHES}

THE FINCHES

THE GOLDFINCH (Carduelis eligans) $\quad \ldots$

THE LINNET (Linota cannabina)

THE TWITE (Linota flatirostiis)

THE I.ESSER REDPOLE (Linota rufescens)

$1 \mathrm{HE}$ SISKIN (Chrysomitris spinus)

THE CHAFFINCH (Fringilla calebs)

THE BULLFINCH, GREENFINCH, AND CROSSBILL...

... 207

... 2 IO

-.. 2 โ 6

… 222

... 227

... 233

... 2 ;9

... 245

\section{THE SWALLOWS}

THE SWALLOWS

THE SWALLOW (Hirundo rustica)

‥ $\quad \cdots \quad 253$

THE HOUSE-MARTIN (Chelidun urbica) ...

... 255

... 261

THE STARLINGS

THE STARLINGS

THE STARLING (Sturnus i'ulgaris)

$\cdots$

… 269

... 270

THE CUCKOOS

THE CUCKOOS

THE CUCKOO (Cucultus canorus)

$\begin{array}{llll}\ldots & \ldots & \ldots & 279 \\ \ldots & \ldots & \ldots & 282\end{array}$






\section{LIST OF ILLUSTRAT ONS}

THE BLACKCAP WARBLER

THE GARDEN WARBLER ...

THE WHITETHROAT $\quad$..

THE LESSER WHITETHROAT

THE WILLOW WARBLER ...

THE GOLDCRI:ST

THE SHDGE WARBLER ...

THE REED WARBLER ...

THE GRASSHOPPER WARBLER

THE NIGHTINGALE

THE ROBIN

THE HEDGE ACCENTOR ...

THE SONG THRUSH

THE MISTI.E-THRUSH

THE BLACKPIRD

THE RING OUZEL

THE DIPPER ...

THE COMMON WREN

THE TREE PIPIT

THE MEADOW PIPIT

TIIE ROCK PIPIT

THE SKY-LARK ...

THE WOOD-LAKK

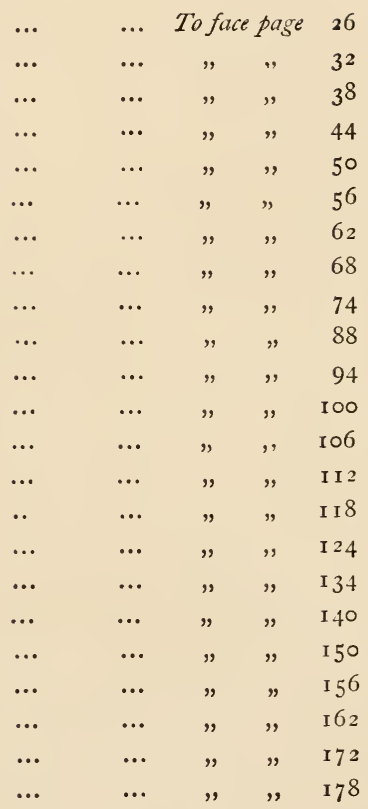




\begin{tabular}{|c|c|c|c|c|c|c|c|}
\hline THE & YELLOW BUNTING & $\cdots$ & $\cdots$ & $\cdots$ & To fc & page & I 88 \\
\hline THE & CIRL BUNTING & $\cdots$ & $\cdots$ & $\cdots$ & $"$ & $"$ & I 94 \\
\hline THE & REED BUNTING & $\cdots$ & $\cdots$ & $\cdots$ & , & $"$ & 200 \\
\hline THE & GOLDFINCH & $\cdots$ & $\cdots$ & $\cdots$ & , & $\Rightarrow$ & 210 \\
\hline THE & LINNET $\quad \cdots$ & $\cdots$ & $\cdots$ & $\cdots$ & $"$ & $"$ & 216 \\
\hline THE & TWITE $\quad \ldots$ & $\cdots$ & $\cdots$ & $\cdots$ & $"$ & $"$ & 222 \\
\hline THE & LESSER REDPOLE & $\cdots$ & $\cdots$ & $\cdots$ & $"$ & ", & 228 \\
\hline THE & SISKIN $\quad \ldots$ & $\cdots$ & $\cdots$ & $\cdots$ & $"$ & $"$ & 234 \\
\hline THE & CHAFFINCH & $\cdots$ & $\cdots$ & $\cdots$ & ,. & $"$ & 240 \\
\hline THE & BULLFINCH & $\cdots$ & $\cdots$ & $\cdots$ & $"$ & $"$ & 246 \\
\hline THE & SWALLOW & $\cdots$ & $\cdots$ & $\cdots$ & , & ", & $25^{6}$ \\
\hline THE & HOUSE-MIARTIN & $\cdots$ & $\cdots$ & $\cdots$ & $"$ & ", & 262 \\
\hline THE & STARIING ... & $\cdots$ & $\cdots$ & $\cdots$ & $"$ & ", & 270 \\
\hline THE & CUCKOO $\ldots$ & $\cdots$ & .. & $\cdots$ & " &,, & 282 \\
\hline
\end{tabular}






\section{OUR FAVOURITE SONG BIRDS}

\section{INTRODUCTION}

A FEw general remarks upon the Songs of Birds appear to us to be the most applicable way in which to introduce to the reader the more particular subject matter of the present volume. In the first place it may prove interesting to sketch briefly the general features of bird song through the year. Birds by no means sing promiscuously. They have their times of song as well as their intervals of silence, and these vary a good deal with individual species. Fortunately our favourite song birds are scattered very generally over the country; there are very few places indeed where the music of some bird is not heard; whilst the best cultivated and more populous areas are literally crowded with songsters of every grade of excellence. Spring and early summer is the great season of song: autumn and winter melody is scarce and fitful. Let us run briefly through the 
months, tracing the commencement and gradual increase of avine song and then its similar decline -like the swelling melody from some stupendous organ-pipes, beginning in low and fitful strains, then rolling and swelling out in grand majestic cadence, then fading away like the fainter and fainter vibrations of an oft-repeated echo as the year completes its course.

In January the Mistle-Thrush is by far the most prominent singer; his loud carol may be heard each day from the tall leafless trees, very often amidst driving rain or sleet or the howling of the wind. The Robin is the next chorister of importance, and his cheery hope-inspiring strains are a daily promise of better and warmer days in store. The IIren, too, sings pretty generally throughout the first few weeks of the opening year, but there are days in this month when his voice may be hushed; still more irregularly does the Hedge Accentor warble. The days are at present all too cheerless to woo him into constant voice. Not so the Starling, for he is another chorister that warbles freely during the entire month, although his voice is somewhat constrained and fitful. Two other birds deserve passing notice. They are the Song Thrush and the Sky-Lark, for both may be heard to sing, the former especially, but in the southern counties chiefly. These half-dozen singers relieve the monotony of one of the most dismal months of the year; we might liken their music to 
the first few preliminary strains of an orchestra about to commence in real earnest. February shows, on the one hand, a perceptible decline in the voice of the Mistle-Thrush, and an equally apparent increase in the melody of the Song Thrush. There are days now when the former bird is silent or fitful in voice, but the latter bird sings more and more freely right through the month. Now, too, the sweet-voiced Blackbird may be heard at intervals trying over his long-lost song. The Robin sings with increasing freedom; the IVren and the Hedge Accentor much more regularly. The Starling's song becomes more persistent, and the Sky-Lark may fairly be said to resume its usual song towards the end of the month. Should the season be mild and open the Wood-Lark too regains its voice. Two other familiar birds regain their song in February, the Chaffinch and the Yellow Bunting.

March may be said to mark the real commencement of the vernal chorus which is soon to swell into such a perfect torrent of song that each individual singer will almost lose his identity in the growing volume of melody. One notable exception, however, is presented in the Mistle-Thrush. All through the boisterous days of this month, when spring seems ever struggling with winter for supremacy, the "Stormcock" sings with waning power, and is often silent altogether for days. The Song Thrush now is in full voice, and the Blackbird's mellow song 
increases. The Robin is also in full song, but the IVren sings by no means regularly or constantly yet. The Hedge Accentor may now be said to have quite regained his voice for the spring; the Yellow Bunting and the Chaffinch nearly so. The Starling is a constant singer now ; the Sky-Lark nearly so. Now too the Linnet and the Twite resume their song; the Reed Bunting sings frequently ; the IVood-Lark becomes much more vocal. The Dipper also resumes his song in an irregular sort of way, as also does the Cirl Bunting; whilst during the last few days of the month the Greenfinch's twittering song may be heard occasionally. The first of the summer migrants now reach our English shores, but neither the Wheatear nor the Chiffchaff lay claim to musical skill. The note of the latter bird, however, is a characteristic one in the southern woodlands during the closing days of March and onwards through the summer in all localities.

April, with its warm sunshine, its balmy airs, and its fleeting rains, marks a rapid change in the melody of the birds. One singer, however, now loses his voice, for during the last half of this month the Mistle-Thrush becomes silent. This is the solitary exception, so far as our British singing birds are concerned, for every other may now be heard in brilliant voice. The Song Thrush, the Blackbird, the Robin, the Wren, and the Hedge Accentormost familiar of all our singing species-are now 


literally overflowing with song. The Cirl Bunting is now in full song, so too are the Dipper, the Lesser Redpole, the Linnet, and the Twite. Among the resident birds that regain their song in April, mention may be made of the Meadow Pipit. The songs of our summer migrants may now be heard in rapidlyincreasing volume. The sweet-voiced Blackcap is heard from the middle of the month onwards, so too is the Willow Wren. During the last week of the month we hear the Tree Pipit and the Whitethroats, and the glad welcome "song" of the Cuckoo resounds once more from the old familiar woods. The Goldcrest is again in full song; whilst the same may be said of the Wood-Lark and the Sky-Lark. The Ring Ouzel has returned to the moorlands and his wild lay is added to the general chorus. April is undoubtedly a month of song, but the music of the birds is by no means constant and complete; one or two singers have but lately arrived and are scarcely in song; but the voices of such birds as Thrushes, Starlings, Finches and Larks are almost if not entirely at their best.

May is the one month of song predominant over all the rest. One singer has vacated his place entirely in the general orchestra (the Mistle-Thrush), but all others seem as if they would absolutely dissolve in song. Each sweet singer of the woods and fields is now in fullest voice. The various Warblers make the thickets and hedges sweet with a volume 
of varied and almost continuous song; the higher trees are resonant with the songs of Buntings and Chaffinches, the evergreens with the love-notes of Bullfinches, Greenfinches and Goldcrests; the open breezy fields re-echo the song of the Tree Pipit, the IVood-Lark and the Redpole; the water-side the persistent melody of Sedgre-bird, Reed WVarbler, Reed Bunting and Dipper. Intermingled with this burst of song, the sweet plaintive minstrelsy of Robin and Wren and Accentor is heard continuously; whilst the gorse coverts and thickets are full of singing Linnets and skulking Grasshopper Warblers. The Thrush and Blackbird are in constant and splendid voice, the Sky-Lark sheds a torrent of song from the clouds. The sombre Nightingales are now in almost overpowering voice; the Swallow and the Martin sing at intervals as they fly along, or briefly rest. Morning and evening are the times to hear this matchless orchestra at its best ; for then whichever way we may turn some sweet warbler or another greets us gladsomely; here, there and everywhere the songs of birds are sounding. From before dawn until the sun's rays gain too much power, and then in the late afternoon until dusk the crash of song is bewildering. June is almost an exact counterpart of May so far as concerns the songs of birds. It is another month of almost constant song, a little less energetic perhaps as a whole, but certainly one of the two most musical months in the 


year. The earlier singing species, such as Thrushes, Wrens, Robins, Accentors and Chaffinches, show a trifling falling off. The one singer, however, whose note appears to suffer greatest decline is the Cuckoo, and towards the end of the month especially his mellow call is harsher and the first note is sometimes repeated, a sure sign of its approaching cessation.

July brings many important changes in the music of the birds. The Song Thrush and the Blackbird become silent during the first three weeks; the Robin loses his voice after the first ten days or so. The Wren and the Hedge Accentor, however, warble pretty regularly throughout the month, as also do the Yellow Bunting, the Greenfinch and the Sky-Lark. The Willow IWren sings pretty constantly through the month, but the Starling is now an irregular songster. The Blackcap usually becomes silent during the first week, the Whitethroats a little later: the Tree Pipit and the Chaffinch seldom sing after the middle of the month; the Meadow Pipit and the Cuckoo are mute after the first eight days. The song of almost every species is hushed some time in July. The reader may be pardoned for inquiring the cause of this silence. This universal hush is due to the approach of the moulting season, a period during which no bird at liberty is known to indulge in song. August is a particularly quiet month amongst the singing birds; but it is remarkable for one or two events in 
the musical life of our favourites. Towards the very end of the month the Mistle-Thrush regains his song after a four months' silence; but the Robin after the first week may be heard in voice, either the young males, or the earliest of the newly moulted old males. The Wren sings very irregularly through August; the Hedge Accentor becomes silent during the first half of the month; whilst the Willow Wren, now in its moult for the most part, is but a fitful songster. The Blackcap, the Garden Warbler, the Whitethroats, and other kindred species are silent altogether; the Starling sings occasionally. The Pipits now are mute; the Chaffinch and the Sky-Lark have lost their sony. The Yellow Bunting and the Greenfinch may be heard in song during the first half of the month only, then their voices sink to rest for a season.

September is another month of fitful song. Bird music is now scarce again, and the few songs that are heard are consequently prominent amongst so much silence. One of the loudest songsters of the month is the Mistle-Thrush, who has now completely regained his splendid voice, which may be heard daily. The other British Thrushes are absolutely songless; but the Robin is now in brilliant tune again, and his charming song is one of the most beautiful features of the closing year. The Wren is silent during most of this month, but regains his voice during the last few days; whilst the Hedge 


$$
1
$$



Accentor less frequently keeps him company. Curiously enough the Willow Wren regains his song in September, just before he leaves us, but it is odd birds only that now break into music. The Starling sings at varying intervals, as he will continue to do right through the winter, as also will the Sky-Lark. Now and then during the last ten days of the month the Chaffinch may be heard to sing fitfully; the Yellow Bunting sings irregularly; the Greenfinch a little during the closing half; the Pipits and Warblers remain mute until the following spring. October is very similar to September in the character of its song. The Mistle-Thrush, of course, is in fine voice; and very rarely the Song Thrush and the Blackbird, now safely over their moult, may be heard to sing a little, mostly young birds gaining the first rudiments of their musical education. The Robin sings with admirable persistency and regularity throughout the month; the Wren and the Hedge Accentor much more frequently than before, although in a decidedly irregular manner. The Chiffchaff and the Willow Wren may sometimes be heard during the first week of the month, but not after; they then finally quit our country for the winter. All the Warblers are gone south to their winter resorts; but the voice of the Chaffinch, sounding strangely out of season we always think, may sometimes be heard, as also that of the Yellow Bunting. The Greenfinch not unfrequently 
breaks out into song during October, the Sky-Lark occasionally. Sad November still more reduces the sum of avine song, and but three species can be classed as regular singers. These are the MistleThrush, whose song only seems to gain in power and beauty as the weather becomes more and more inclement; the Robin and the Wren, whose melody gladdens our hearts like the voices of old familiar friends amidst the general desolation of the ruined choirs. The Hedge Accentor is a capricious songster now, and the least inclemency of weather will close his jerky music at once. Our old friend the Starling still delights us at intervals, and the SkyLark during exceptionally favourable weather is tempted to soar heavenwards in a fitful burst of song. December, again, is marked by little variety of bird music, although the month is by no means a silent one. Songs are sung more fitfully, much depending upon the weather, but a warm day is sure to be a musical one in some degree. Cock Robin remains faithful to his muse, and the MistleThrush gladdens us amidst the wintry sadness with his voice. The Wren and the Hedge Accentor (especially the latter) sing on at intervals, but the Starling becomes perceptibly more musical. Here and there in the scuthern counties a Song Thrush breaks into fitful song, and a warm day still continues to tempt the Sky-Lark to musical effort. This completes the song cycle of the months, bringing us 


to the dawn of a new year, when every note but hastens and foretells the approach of yet another glorious concert swelling and declining as another season passes on.

The various actions of birds whilst singing are not without interest, and are also an aid to the identification of the species uttering them. Amongst some species the habit of soaring predominates, as with the Pipits, attaining its greatest development in the Sky-Lark. Other birds accompany their song with nervous movements of the wings, or vibrations of the plumage, as for instance the Starling. Most birds sit or stand perfectly still whilst uttering their song, but the Swallow and some other species warble most freely as they fly.

We may profitably conclude this introductory chapter with a few remarks on the philosophy of avine song. The song of birds, there can be little doubt, is one of the many forms in which natural beauty is expressed. Some birds display their charm by a wonderful adornment of colour, by glowing plumage, by painted wings, by flowing plumes or handsome crests. These birds do not sing. Throughout the bird world it is exceptional for a fine songster to be decked in brilliant plumage; all our best singers are clad in sombre or inconspicuous plumage. Another fact of some interest is the extraordinary variety of song. Few species form their music out of the same combination of 
notes, and it is a fact which every observer will soon recognize, that very closely allied birds differ to an astonishing degree in the quality of their voice. We could not have a better example of this than that furnished by the Willow Wren and the Chiffchaff. These two birds are so much alike that it requires a person with some considerable knowledge to distinguish them, yet the songs of the two species are so utterly dissimilar that no one could possibly confuse one with the other. The Willow Wren's song is sweet and plaintive, a little run of beautiful notes; whilst that of the Chiffchaff is a monotonous double cry, not easily mistaken for that of any other British species. If we admit that song is a secondary sexual character this diversity need not surprise us, for of all characters this is the most variable IVe may here remark that only in the Passeres do we find birds of true songbirds which are distinguished from all others by the organs at the end of the windpipe being specially developed for the production of these sweet sounds, the sweetest by far in all animated nature. This organ of voice, technically called the "syrinx," is really a modification of the lower part of the trachea, and consists of a series of muscles attached to the extremities of the bronchial semi-rings.

There has been much diversity of opinion expressed concerning the origin and purpose of Song. It is a popularly prevailing idea that song, 


or the instinct of song, amongst birds, is but an outward expression of exuberant internal joy. But there is overwhelming evidence to suggest that this wondrous accomplishment originated in Sexual Rivalry, developed and perfected, fostered and increased by that stronger and more assertive vitality which is without exception so characteristic of birds with any pretensions to musical skill. We, however, hasten to admit that these musical acquirements are also employed to express joy, and are even widely indulged in as a pastime or pleasurable diversion; many species singing more or less constantly throughout the year, and even when sexual rivalry is dormant. But it is a rule without any exception whatever, that all birds sing their best when inspired by Love, and that in no case does this music show the faintest decline in power at a season when amorous instincts are predominant. Song each season is resumed at the commencement of sexual rivalry, and dies completely away with the decline of that sexual stimulus. Sexual rivalry and song are therefore inseparable; wherever there is music there is love, or what pertains thereto. Every person who pays close attention to the subject will find that song declines perceptibly in brilliance and persistency after the laying season is over and the more acute stages of sexual strife are passed. The singing period of all song birds is a season of irritation 
and war. Rival males sing at each other, chase each other from tree to tree or through the branches, fight fiercely, and sometimes seem so lost in their ecstatic rage as to be utterly oblivious to their own personal safety. Birds have been known actually to die under the violent exertions of song that a rival has inspired. Robins, to take a homely instance, often get so excited whilst singing against a rival that their song breaks into harsh sounds which are nothing but screams of defiance. We have often watched rival males of this species gradually approach each other singing at intervals between each stage of their progress, and then finally engage in combat. Mild temperature and abundance of food may be a strong incentive to song, but only indirectly as these conditions affect the sexual impulses.

Another branch of this interesting subject which the student must not fail to notice is the very perceptible amount of Variation in the songs of individuals of the same species. This is a very difficult study, for it requires a fine musical ear and some training; and yet it is one that has hitherto received little attention, although a most promising and pleasing field of inquiry. We have repeatedly remarked variation in the songs of the same species in widely different localities, especially in the notes of some of our common birds in Algeria. Captain S. G. Reid states that the resident Chiffchaffs in 
the Canary Islands, for instance, have acquired a much longer and desultory song than is heard from this species elsewhere. The late Lord Lilford has recorded an instance of very peculiar variation in the song of the Robin. It is also rather difficult to say what is real variation in a song, or what may be due purely to imitation. Mr. C. A. Witchell in his little work entitled The Erolution of Bird Song, has recorded a great many instances of what he considers legitimate imitation. But we think he assumes too much, and that a great deal of what he attributes to an imitative faculty is nothing but a similarity of coincidence; whilst we cannot refrain from saying that this author should have been more carefu! to acquaint himself with what other naturalists have already written and suggested before making so many dogmatic statements, or claiming as novelty much that had long been published. And here we may repeat what we wrote several years ago on yet another branch of this intensely interesting subject: The standard of perfection or excellence in the songs of birds is by no means an uniform or constant one. This is especially remarkable at the period when a species resumes its voice after a long interval of silence, and in the maiden efforts of young individuals. Any moderately observant person may remark innumerable instances of this peculiarity in every singing species. Looking through our note-books we find many observa- 
tions recorded, all showing that when the song is regained it is frequently far from perfect. For days the singers seem unable to utter the song complete. In the case of the Chaffinch and the Yellow Bunting, for instance, we have repeatedly remarked that the final notes of the song have been omitted to the extent of ninety per cent.! In many cases for a few days nothing but a series of disconnected twitterings have been uttered by some species, as though the birds were trying to recall their long-lost song. We have remarked the same thing in a Mule Canary, after his moult. Many young birds are very indifferent songsters, the art having apparently to be learnt with considerable effort. Especially is this apparent in the case of young Robins, which sometimes begin to sing belore they have quite lost the spotted dress of their youth. Some fully adult individuals of probably every species are much finer songsters than others, the music apparently improving with the age of the bird up to a certain period. We might here remark, that in some few cases the female has been known to acquire musical powers of high merit; whilst in most others the power of song is confined to a few low twittering notes-which probably represent what was once the best performance of the male at an earlier period in the history of the species, the crude beginning of a song which he has eventually developed into music of bewitching sweetness. Several instances 


in which the female bird sings as well as the male are given in future pages of the present work. The various call-notes of birds are equally worthy of study; they will be found described under the several species, and should on no account be ignored, as they are, to say the least, valuable aids to the identification of the birds themselves.

Do birds sing by Instinct or by Imitation? It is a very popular belief that birds are hatched with an inherited ability to sing like their parents; that when the proper season arrives these young birds without tuition or experience warble off the song characteristic of their species. This is an utterly erroneous assumption not supported by a scrap of direct evidence. Daines Barrington, no mean authority although an old one, writes: "notes in birds are no more innate than language is in man, and depend entirely on the master under which they are bred, as far as their organs will enable them to imitate the sounds which they have frequent opportunities of hearing." He further tells us that he has "educated nestling Linnets under the three best singing Larks-the Sky-Lark, Wood-Lark, and Titlark, every one of which, instead of the Linnet's song, adhered entirely to that of their respective instructors. When the note of the Titlark Linnet was thoroughly fixed, I hung the bird in a room with two common Linnets for a quarter of a year, which were full in song; the Titlark Linnet, how- 
ever, did not borrow any passage from the Linnet's song, but adhered steadfastly to that of the Titlark." Every bird-fancier knows how readily under suitable conditions young birds will acquire a song totally unlike the one characteristic of their species. Many other similar facts might be brought forward to prove that the songs of birds are acquired by imitation, and that if young birds never hear the song of their species they are totally unable to produce it. A bird's song is just as much an acquired faculty as the acquisition of a language by a child; and young birds, as Dr. Wallace pertinently remarks, "must be taken out of hearing of their parents very soon, for in the first three or four days they have already acquired some knowledge of the parent notes, which they will afterwards imitate." Having said this much by way of introduction, we hope we have indicated various directions in which the study of Avine Song may be pursued with profit. There are many ways in which the songs of birds are instructive, and their philosophy may be studied with advantage whilst their varied strains are appealing to our sense of enjoyment. Our favourite song birds shall now be reviewed in proper sequence. 


THE WARBLERS 





\section{THE WARBLERS}

Some systematists are disposed to class the Crows as the most highly specialized of all known birds; and if certain peculiarities are considered their right to the distinction seems to be beyond question. Other naturalists have similarly urged the claims of the Thrushes to that honour, but with less satisfactory evidence to support their views. The Crows, as was long ago remarked by the illustrious Macgillivray, rank amongst some of the most highly organized birds. This assertion was based not only upon great anatomical, but wide general knowledge, and has been abundantly confirmed by later investigations. This exalted position of the Crow family (Corvida) is largely due to the very interesting morphological fact that the young birds resemble the adults in colour, a fact which assuredly indicates higher development than is attained by the majority of other birds-and perhaps all other groups collectively -in which the young are more or less characterized by a plumage differing in many important respects from that of their parents. Tested by this 
fact the Thrushes (Turdina) with their spotted young must justly give up their claim to precedence in favour of the Warblers (Sylviina), in which the young almost universally very closely resemble the adults in colouration. There can be no doubt that of these two groups the latter is the most advanced from a common ancestor with spotted plumage, and therefore justly claims the post of honour in the present volume.

Fortunately it is not our province here to attempt to define the limits of the Sylviinæ-a group which scarcely two systematists agree as to the species claiming to be included. Possibly with the addition of many forms at present excluded it may yet claim to be elevated to a family rank. For our present purpose it will be most convenient to follow the arrangement adopted by Seebohm in the fifth volume of the British Museum Catalogue of Birds. 'The Warblers, as there restricted, number several hundreds of species distributed over the greater part of the Old World, but only a very small proportion of these can be fairly classed as "British." The "American Warblers" form a distinct family, Minotiltidæe, peculiar to the New World, and are characterized, among other things, by having nine instead of ten primaries in the wing. Both groups are essentially of Inter-Tropical origin, and in the majority of instances are able only to exist in colder and temperate latitudes by the exercise of migratory 
habits. The typical Warblers are not remarkable for any great variety or beauty of plumage, their clothing is exceptionally chaste and unassuming; but on the other hand their New World representatives are more brilliantly adorned-probably at the expense of vocal power. Amongst the Old World Warblers are to be found some of the sweetest singers of all known birds. They are essentially a musical group, but their vocal qualities are of very varying degrees of excellence, not only between the less nearly related species, but amongst others which are apparently very closely allied. To some extent it would seem that the quality of the voice was correlated with generic distinctions. In the Grasshopper Warblers (Locustella) the song is most monotonous; in the Reed Warblers (Acrocephalus) it is certainly more musical, but of very unequal merit; in the Willow Warblers (Phylloscopus) it is also of variable musical quality; in the Bush Warblers (Cettia) it attains considerable beauty; in the Tree Warblers (Hypolais) certainly more; whilst in the typical Warblers (Sylvia) it probably reaches its highest degree of attractiveness. Yet of all these groups not one (even of exceptional claim to musical skill) can be mentioned in which the song is of equal merit in all the species comprising it. In every group specially remarkable for vocal power some species invariably introduce discord, their musical abilities falling immeasurably short $\mathrm{c}^{\mathrm{f}}$ the standard 
of excellence reached by the most favoured members. This generic resemblance also extends very notably to the eggs, but as oology is of only secondary importance in the present book we need not make more than a passing allusion to the interesting fact. Certain species of Warblers are remarkable for the extraordinary way in which their vocal efforts resemble those of other and often remotely allied birds; this, we believe, is not conscious imitation to anything like the extent that has been ascribed to it by certain writers, but pure coincidence. Of the bircls in this group which are not British, and yet famous for their vocal acquirements, mention may be made of the following. The Icterine Warbler (Hypolais icterina), or Tree Warbler, as it is called in some localities, is a particularly loud and persistent singer. The song is almost as loud, and certainly quite as varied as that of our own Song Thrush; it has also the peculiarity of being repeated every few notes many times in succession, a fact which also increases the similarity. This melody has been much over-rated, but certainly exceeds that of the Sedge Warbler with which it is often compared. Cetti's Warbler (Cettia cetti) and some of its allies are said to possess a song almost rivalling that of the Nightingale; and what is even more interesting, to continue in voice almost throughout the year. The Orphean Varbler (Sylvia orphea) almost excels the Blackcap in the melody and richness of its voice; 


whilst the Barred Warbler (Sylvia nisoria) possesses some notes of exquisite sweetness. Some of the smaller Warblers in the genus Sylvia are also remarkable for their vocal powers. Of these we may mention the Sardinian Warbler (Sylvia melanocephala), Tristram's Warbler (Sylvia algeriensis), and the Spectacled Warbler (Sylvia conspicillata). The Rufous Warbler (Aedon galactodes) has a peculiar song more resembling that of the Robin, and described by one competent authority as low, soft and mellifluous. None of the Willow Warblers (Phylloscopus) appear to excel our own familiar Willow Wren (P.trochilus), in their musical attainments. The Warblers, as a rule, sing during the early part of the breeding season only. The British Islands are specially favoured with birds of this group, some of the finest songsters in the entire series being summer visitors to our country, and these we will now proceed to describe in detail. 


\section{THE BLACKCAP WARBLER}

\section{SylviA ATRICAPILLA}

Witu the solitary exception now of the Dartford Warbler all the species in the present group are summer migrants to the British Islands. The excessively local and rare Savi's Warbler was once said to be a resident in the fens, but the drainage of its favourite haunts has apparently caused its complete extermination, and thus left the Dartford Warbler in sole possession of the peculiarity of permanent residence with us. In our islands England and Wales are the Blackcap's head-quarters, but even here the southern and south-western districts are the most favoured, whilst everywhere there is a strongly marked tendency to localness. In Scotland and Ireland it is rarer and even more locally distributed, especially in the latter country. South of latitude $66^{\circ}$ in the west, and lat. $57^{\circ}$ in the east, the Blackcap is generally distributed over continental Europe. Southwards it extends to North Africa (with the adjoining islands), and east- 


$$
\text { \& }
$$





wards to Asia Minor, Palestine and Western Persia. In some of the more southern portions of its range (practically throughout the basin of the Mediterranean) it is apparently a sedentary species, but its winter limits extend in Africa to within ten degrees of the equator.

The Blackcap makes its appearance in the British Islands during the first half of April, a little earlier in the southern districts than in the northern ones. Thus in South Devon, where this bird is exceptionally common, I find the date of arrival to be on an average the Ioth of April ; in South Yorkshire it is about a week later. In places where it is common the Blackcap is most ubiquitous in its choice of a haunt. It may be met with in all sorts of places, in gardens, orchards, hedges, plantations, shrubberies, woods, and the dense thickets by the side of streams. We have repeatedly remarked its partiality for, and its exceptional abundance in, the vicinity of houses ; it is therefore perhaps the most familiar and the best known of the typical British Warblers. Arriving as it often does long before the trees are in full leaf, and given to song almost directly after its appearance, it cannot readily be overlooked. It is neither so shy nor so skulking in its habits as the Garden Warbler and the Whitethroats, and as often as not may be watched for minutes in succession on the bare branches as it sits and sings fearlessly within a few yards of the observer, every now 
and then fluttering into the air to seize a passing insect.

To the casual observer the Blackcap generally proclaims itself by its song. The males appear to arrive a day or so before the females, but as soon as the latter come music begins, and is continued with almost undiminished vigour until the end of June, the song finally ceasing for the year early in July. The song, however, is never given forth so vigorously as in the first few weeks of spring; the bird then seems literally overflowing with music and warbles almost continuously the livelong day. He is by no means a retiring singer, but may often be watched in the less tangled branches, now low down in the underwood, anon high up the trees. Not only does he sing whilst sitting on some branch, but as he flits from one spray to another, and even occasionally whilst on the wing. If disturbed from one place he will immediately flit off to another at no great distance and recommence his song at once. Of all the IVarbler band the Blackcap, to our mind, is the most splendid singer, and his melody is absolutely unrivalled. The notes, clear and flutelike, pour forth in a perfect torrent of wild, sweet melody full of the most pleasing variations, and so loudly uttered that the listener is often led to think that a much larger and more powerful singer is producing them. Often the very nearness of the song is absolutely startling, and as we stand 


entranced listening to its powerful cadence we may notice the black-capped little musician quietly sitting amongst the vernal foliage, with head turning from side to side and throat bubbling with the exertion, trying his hardest to drown the efforts of a rival in a neighbouring tree. The modulations of the song are exquisite. First, it may be, the song is heard in a low key, as if the author of it were a hundred yards away; then gradually it becomes louder and louder, giving us the impression that the bird is coming nearer, until finally we are greeted with a torrent of sound, as if Blackbird, Song Thrush, Wren, Robin and Warbler were all singing in concert. But the Blackcap has been stationary all the time; it may be not half-a-dozen yards away, and in amazement we learn that this wondrous music, now low and soft, anon rich and loud and full, has issued from the same little throat at one unchanging distance! Next to the exceeding sweetness of the song, the pertinacity of the singer is sure to strike the observer. All through the balmy days of April, May and June the song may be heard, and not unfrequently it mingles with that of the Nightingale and the Sedge Warbler during the hot, sultry, summer night. Nay more, the Blackcap occasionally sings whilst taking his turn upon the eggs. At least one eminent authority thinks this "hardly credible." But we can assure the sceptics of the fact, after having watched the 
bird so engaged, as we peeped between the underwood not six feet away, scarcely daring to breathe, and seen the little singer, quite unconscious of our presence, crouching low on the flimsy nest warbling loudly with trembling throat and dark eyes flashing defiance. It is said that the Blackcap sings during the winter in the south of Europe, but this we think is a mistake, for February (the date given) in Italy is quite equal to April in England, so far as many of the habits of birds are concerned. The Blackcap is a very defiant singer, like the Robin in this respect, brooking no rivals, and trying its best to out-sing every other bird within hearing. It is at these times that the song is heard to best advantage. The call-note of this species is similar to the sound produced by knocking two small pebbles togethera clear tec or tack deliberately repeated. As soon as the eggs are hatched the song of the Blackcap begins to wane.

Towards the end of April Blackcaps commence nesting duties. The nest is a slight cup-shaped structure made chiefly of dry grass-stalks, roots, cobwebs and cocoons, and lined with a little horse-hair. It is usually placed not far from the ground (from three to ten or twelve feet) in thickets, in dense hedges, gorse-bushes, or in holly and other low trees. A site is often selected near to running water, and the nest is not unfrequently slung in the branches drooping over a stream. The eggs, laid 


at the end of April, in May, or even in June, are four, five, or six in number, usually white in groundcolour, clouded with olive- or buffish-brown, and here and there spotted and streaked with dark brown. A rare variety is pale red, mottled with darker red and sparingly spotted and streaked with purplish-brown. But one brood is reared in the season. If the first nest comes to grief, another and yet another will be made. A peculiarity of this species is that it will continue to lay the full clutch of eggs in the same nest, if they are as regularly removed as soon as laid. The food of the Blackcap is chiefly composed of insects and larvæ, but berries and fruits of various kinds are also eaten. The bird leaves our islands in September.

The Blackcap has the general colour of the plumage greyish-brown, palest on the under parts. In the male the upper part of the head is black: in the female it is rusty brown. The bird is a little over six inches in total length. 


\section{THE GARDEN WARBLER}

\section{SYlvia HORTENSIS}

The Garden Warbler is even more locally distributed in the British Islands than the Blackcap. It is decidedly an English species, its range in Wales, so far as is yet known, not reaching beyond Pembrokeshire and Breconshire; in Scotland to the southern and central counties only; whilst in Ireland it embraces the counties of Cork, Tipperary, Fermanagh, and Antrim, and possibly those of Dublin and Wicklow. Its extra British range is very similar to that of the preceding species, but is a little more northerly, reaching lat. $70^{\circ}$ in the west and lat. $65^{\circ}$ in the east. Its eastern limits are about the same, but it appears only to pass South Italy, Greece and Asia Minor on migration, breeding however in Palestine and North-western Persia. The winter home of the Garden Warblers breeding in the northern hemisphere is in the African portion of the Inter-Tropical Realm.

The Garden Warbler is a later migrant than the 


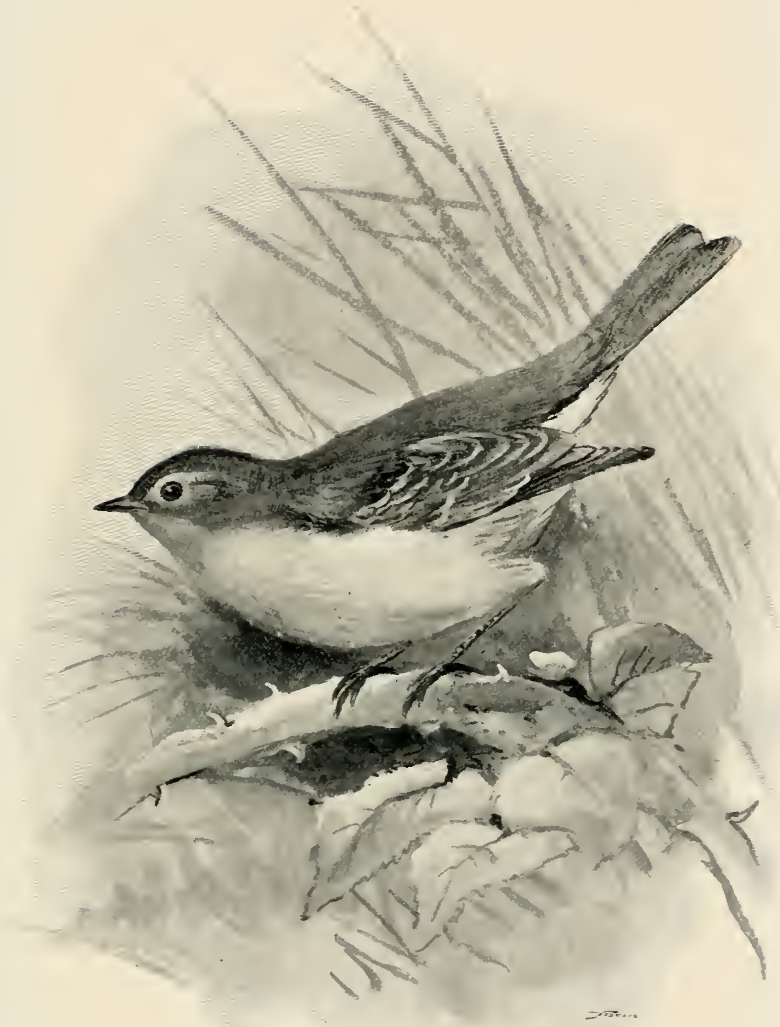

rensy Stannard

Garden Warbler 

Blackcap, not reaching its British haunts before the end of April or early in May. Although very similar in its habits and in the haunts it frequents to the latter bird, it is much more retiring and apt to be overlooked even in districts where it is comparatively common. It should also be remarked that in localities where the Blackcap abounds the Garden Warbler appears to be proportionately scarce, but whether this is due to the antipathy of the birds for each other's society, or the absence of some favourite food, or necessity of actual existence, we are not exactly prepared to say. Cover of some kind is most essential to this unobtrusive and skulking bird. It delights in thickets, the tangled underwood in plantations and shrubberies, fruit gardens, orchards, dense hedges, and the interlaced vegetation growing near to streams. As in the Blackcap, the male Garden Warblers appear to migrate a few days in advance of the females; and with their advent song commences. The Garden Warbler is of a most retiring nature, delighting to thread its way through the tangled branches with mouse-like celerity, every now and then indicating its whereabouts by uttering a harsh teck, or less frequently by bursting into song. On rarer occasions it may be seen amongst more open situations, sometimes at a considerable height in the trees, whence it now and then soars into the air to capture an insect ; but our experience of this species invari- 
ably is that it seeks to hide itself from observation almost directly it feels itself to be an object of scrutiny.

During the breeding season the Garden Warbler usually proclaims its presence by its song. Generally the sweet little singer is safely hidden amongst the bowers of dense vernal foliage, and so quickly does he glide from one part of the cover to another that at most a fleeting glimpse is obtained. There is but one other British Warbler that can outrival the present species in vocal power, and that is the Blackcap. If this bird be not present for direct comparison there is little in the quality of its voice to mark inferiority. It certainly is a softer, more subdued song, wanting that loud flute-like joyous character which is such a feature of the Blackcap's melody, but it is exquisitely sweet notwithstanding. It is a song which, to us, always leaves the impression that the singer is bashful, and alarmed at its own temerity in venturing to join in the springtide chorus at all-a song which expresses in sweetly eloquent language the unassuming disposition of the great vocalist himself, a characteristic of much human as well as avine genius. The Garden Warbler is certainly not such a persistent singer as the Blackcap; it is more fitful, and heard to best advantage in early morning. The song, as is usual in this group, is continued until the eggs are hatched, when it abruptly dies away for the year. 


From notes made during a great number of years, recording observations on the song of the Garden Warbler, we find that it is in fullest power during May and the first half of June; that the bird sings little during inclement weather; and lastly that on very rare occasions it may be heard warbling on still, hot summer nights. The typical Warblers are not anything like such night-singers as the Reed Warblers, and we are inclined to think that in most cases their night song is due to their being disturbed, and not from any natural nocturnal habit.

The breeding season of the Garden Warbler is in May and June. The birds apparently pair after their spring migration, and nest-building commences very soon after that event is settled. The nest may be found in a variety of situations, but is generally never many feet from the ground. It is variously placed amongst brambles and briars, in low thorn trees, or in gooseberry and currant bushes. In other cases it is placed amongst nettles or in amongst the foliage of growing peas. Wherever it is built, however, the birds are most careful to select a spot in which it is absolutely concealed by surrounding leaves. The nest is a flimsy net-like structure, composed of round dry grass-stalks chiefly, with perhaps a scrap or two of moss and a few roots : sometimes, but not always, a slight lining of horsehair is added. The sides of the nest are skilfully interwoven with the surrounding twigs and stems; 
whilst the inside is moderately deep and beautifully rounded. The eggs are from four to six in number, and are white, or white tinged with buff or green, in ground-colour, blotched, spotted and freckled with olive-brown, dark brown, and buffish-brown, with a few underlying splashes of paler brown and grey. The pink variety, so familiar in the eggs of the Blackcap, does not appear to occur in this species, although we should remark that a single egg in the British Museum, taken by Gould, is ascribed to the Garden Warbler. Personally we doubt its duthenticity. If disturbed from the nest the parent bird (which is a somewhat close sitter) glides very quietly from the place, and threads its way like a shadow through the surrounding vegetation. Harsh tecks of defiance or alarm will soon generally greet the observer, if he persists in staying in the vicinity. We are of the opinion that but one brood is reared in the year. If the first nest and eggs however come to grief a new one will be made and another set of eggs produced-a fact which may often explain the late nests of this bird which are sometimes found, and generally attributed to a second brood. The food of the Garden Warbler is principally composed of insects and their larvæ; but to this fare must be added soft fruits of various kinds, together with the berries of the elder, ivy, and bramble. The young, we believe, are principally reared upon larvæ of insects. The autumn migra- 


tion south of this Warbler begins in August, and is completed, so far as our islands are concerned, in September.

The Garden Warbler has the general colour of the upper parts olive-brown, darkest on the wings and tail; the under parts and a stripe over the eye are buffish-brown, shading into greyish-white on the centre of the breast and belly: the axillaries and under wing-coverts are buff. The female is similar to the male in colour, and the total length of both sexes is about six inches. 


\title{
THE COMMON WHITETHROAT
}

\author{
Sylvia Cinerea
}

THIs Whitethroat is undoubtedly the commonest and most widely distributed of the Warblers in the British Islands. It may be found in all districts suited to its requirements throughout England, Wales, and Ireland, whilst in Scotland, although perhaps more local, it is a regular summer migrant to at least as far north as Ross-shire, including Mull, Iona, and Skye. The European range of the Whitethroat is very similar to that of the Blackcap. South of lat. $65^{\circ}$ in the west, and lat. $60^{\circ}$ in the east it is found in most localities; whilst eastwards it breeds in Asia Minor, Palestine, Persia, and South-west Siberia. The winter quarters of the Whitethroat appear to be confined to Africa, and the northern breeding individuals of the species do not cross the Inter-Tropical Realm. A few Whitethroats are said by Canon Tristram to winter in Palestine; whilst Professor Newton says that others pass that season in South Europe and certain 




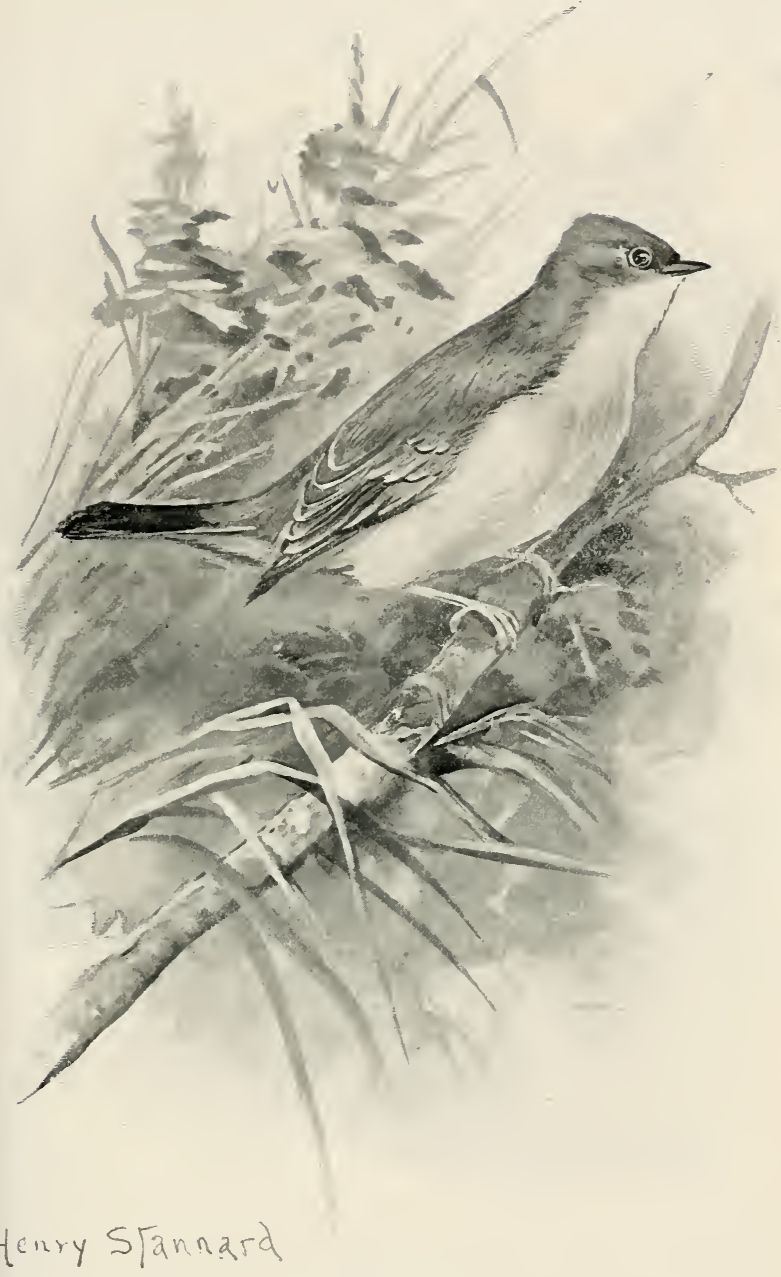

The Whitethroat 

of the Mediterranean Islands, although upon what evidence the statement is made is not apparent.

The Common Whitethroat arrives in our islands about the same time as the Garden Warblerduring the last half of April, or early in May, according to latitude. It is certainly the most ubiquitous of the typical Warblers and may be met with almost everywhere-in the suburban garden or orchard, in hedges by the road-side, in the copses, the fields, and the thickets, or even in moorland districts provided a modest amount of tangled shelter can be found. Although the Common Whitethroat might fairly be described as a skulking bird, it is by no means a shy one. It courts observation rather than concealment during the first few weeks of its sojourn with us, and may then repeatedly be watched clinging to some tall bending twig at the very top of the hedge, singing lustily; if disturbed merely dropping down into the denser cover below, or hurrying off in drooping hesitating flight for some distance, or, as often as not, dropping over the hedge out of sight, and reappearing a little way ahead, to repeat the movement as we walk along. As the breeding season draws on, however, the Common Whitethroat certainly becomes more skulking in its habits. It keeps more closely to the matted, tangled vegetation, where the trembling of a twig, or the harsh scolding note, is the only sign of its presence and its whereabouts. It is often 
almost Tit-like in its activity, restlessly gliding through the cover, now showing itself for a moment, and then disappearing again, thus retreating before the observer for some considerable distance. Although distinctly a bird of the hedges and lower vegetation, it by no means confines itself to such situations, and may frequently be seen high up in the tall trees in quest of insects or busily engaged in song. In addition to the very characteristic scolding alarm-note, the bird has one which sounds like the syllable tay or pay, and another which may be likened to a shrill and sharp weet or wick, both of which are several times repeated.

The male Whitethroat is a very free singer and continues in voice almost from the time of his arrival until the first half of July, when his voice is hushed in the autumnal moult. Although this species does not claim anything like the exalted rank of the two preceding species as a musician, its song has a careless wild beauty which is certainly very attractive. Some of the notes are harsh, but others are sweetly beautiful-it is an up-and-down garrulous little song, with little variety; but what it lacks in compass and tone it makes up in vigour and quantity; for the Whitethroat is a hearty and a most pertinacious singer, warbling at intervals from dawn to dusk, and very frequently during the quiet sultry summer nights as well. Another peculiarity is the bird's habit of warbling whilst hovering in the air. The Blackcap 


sometimes does this, but with the Whitethroat it is a regular habit, and in our opinion one which adds considerably to the beauty of the song. Starting from his perch he will either soar in an irregular manner for some distance, or pass from one hedge or tree to another, singing all the time. These song flights are by far the most frequent during the first few weeks of the bird's visit to us, when love and sexual rivalry are at their highest pitch. During the act of singing the Whitethroat has a habit of erecting the feathers on the head and throat, as it will also do when excited.

The Whitethroat, like most of its congeners, is a rather late breeder, the eggs being laid during May and June. The Whitethroat chooses a variety of situations for its nest, but mostly close to the ground. Occasionally, however, it may be seen in a tall hedge six or eight feet from the ground. A favourite situation is amongst nettles, or other coarse herbage, amongst briars and brambles or in low bushes. A dense whitethorn-hedge, or a gorse-bush, is a favourite situation. The nest, which both male and female assist in making, is deep and flimsylooking, although beautifully rounded inside and much stronger than its appearance might suggest. It is made chiefly of round dry grass-stalks (hence, perhaps, the local name of "Hay-chat" often applied to this species), roots, and perhaps strengthened with a few cobwebs and cocoons, finally lined 
with a little horse-hair. The eggs are from four to six in number, varying from greyish-white to pale green in ground-colour, mottled, spotted, and freckled with various shades of brown and grey. A characteristic of these eggs is the band or zone of markings, usually round the larger end. The female performs most of the task of incubationlasting from eleven to thirteen days-and if disturbed glides from her charge in a very silent and stealthy manner. But one brood is reared in the year, although sometimes two or more nests and as many clutches of eggs have to be produced to gain this end.

Insects and their larvæ, during the earlier part of the summer, form the principal food of the Whitethroat. But later on in the season fruits of various kinds are eagerly sought for, and at this time the bird is a frequent visitor to the garden. It also eats the soft tender green corn with great greediness, and has been known to attack a row of peas. Many insects are secured whilst the bird pursues them in the air; and we have also seen it clinging to the trunks of trees searching the crevices of the bark. There can be no question that the Whitethroat is a very useful little bird to the farmer and gardener, and we should not grudge it a small share of fruit and grain in return. The Whitethroat begins to moult in July and continues to do so until the end of August. During this 


period it is exceptionally secretive and silent. It leares us with its young for the south during September, although a few individuals may be met with as late as October.

The adult male Common Whitethroat has the general colour of the upper parts greyish-brown, shading into ash-grey on the head, and darkest on the wings and tail. The wing-coverts and innermost secondaries are broadly margined with pale chestnut-brown, and the outermost tail feathers are broadly edged with white. The under parts are white, shot with vinous on the breast, and shading into buff on the flanks. The under wingcoverts and axillaries are pale grey. The bird is about five and a half inches in total length. The female wants the grey on the head and the vinous on the breast. 


\section{THE LESSER IVHITETHROAT}

\section{Sylvia CURRUCA}

The name of this little Warbler is somewhat misleading and inappropriate, for its affinities appear to be more with the Garden Warbler than with the preceding species, as we shall learn during our short survey of its life-history. The visits of the Lesser Whitethroat to our islands are chiefly confined to the southern, central, and eastern counties of England. Throughout the west of England and in Wales it is decidedly rare, although it certainly breeds in South Devon. North of Yorkshire the bird also becomes rare, although we can trace it as a breeding species as far as the valley of the Forth. But one instance of its visiting Ireland (on abnormal migration) has been recorded. The Lesser Whitethroat is found during summer over most parts of Europe, up to, or even slightly beyond, the Arctic Circle, and is also a visitor at that season to Asia Minor and Palestine. It is said that a few remain to winter in the south 


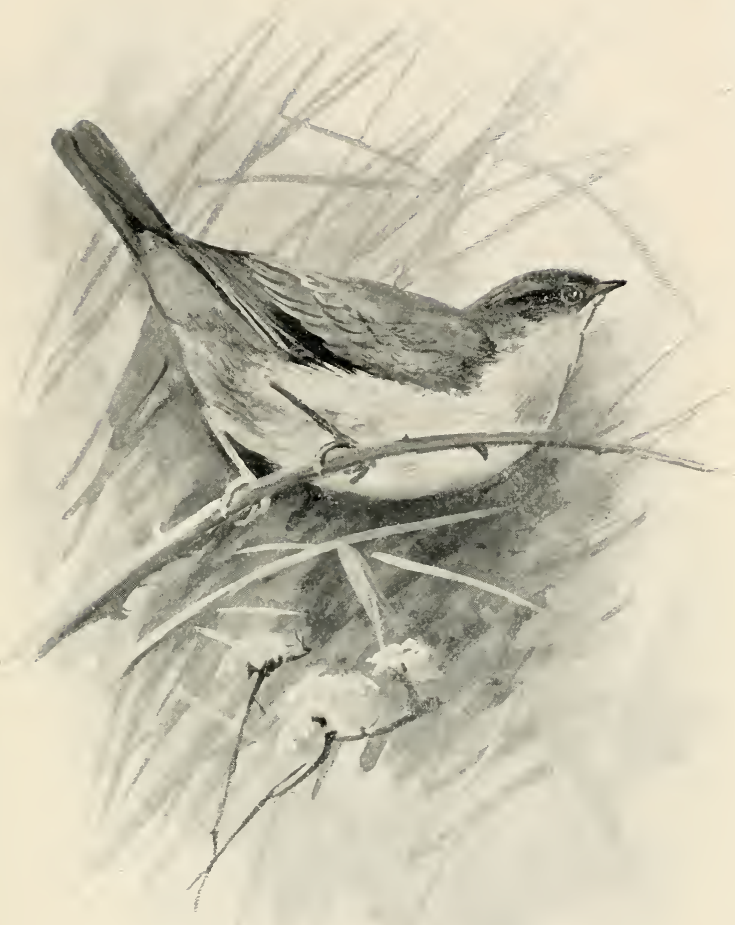

Henrys jundil

THE LESSER WHITETI. ROAT 



of Spain, but the usual haunts are in North Africa from the Desert to within about ten degrees of the equator. Two very closely allied species are found in Asia.

The Lesser Whitethroat undertakes its migrations about the same time as the preceding species, arriving in its English haunts during the last half of April or the beginning of May. In its habits, and the haunts which it frequents, the Lesser Whitethroat very closely resembles the Garden Warbler. It has the same retiring skulking ways, shunning observation and passing most of its time amongst the sheltering foliage; it resorts to similar cover, hedgerows, thickets (especially near to water), large gardens, shrubberies, and coverts, where it has a habit, not so noticeable in the Common Whitethroat, of frequenting the taller trees, and the higher hedges. The partiality of this bird for dense cover, combined with its unobtrusive song, causes it to be much overlooked even in localities where it is fairly common. It has the same secretive ways as the rest of its allies, hopping very quickly and stealthily from twig to twig through the tangled thickets, the trembling of a branch here and there, or the occasional harsh call-note, being the only indications of its presence. If observed in more open places, which happens less frequently, the Lesser Whitethroat will be found to resemble in its actions nearly allied birds. 
It is in the habit of carefully searching the foliage for insects; and when doing so in the loftier trees may be seen to flutter for a moment at the extremity of a twig as it subjects each leaf to piercing scrutiny. Now and then even, Flycatcher like, it starts into the air in chase of a passing fly, and the sharp click of the bill may be heard as it closes upon the unfortunate insect. The call-note of this Whitethroat is a shrill tec; the bird has also a harsh scolding note, very similar to that uttered by allied birds, when alarmed or chased.

The vocal powers of the Lesser Whitethroat can scarcely be described as of a very high order. The first part of the short and to some extent monotonous song is certainly the best, but the promise of the opening strains is not continued, and they soon pass into little more than a trill. This song is uttered rather persistently, especially during the first few weeks of the bird's sojourn in our area, but begins to decline at the close of June, and ceases altogether in July. This Whitethroat may also be heard occasionally to warble whilst fluttering in the air, and still more rarely to sing at night. Some birds take a perfect delight in seeking an exposed perching place from which to sing; but the Lesser Whitethroat courts seclusion and a shady place to indulge in song. As this is neither loud nor very attractive, the poor little singer is often overlooked and his vocal efforts disregarded. 
The Lesser Whitethroat apparently pairs after its arrival in this country. It is a somewhat late breeder, the eggs being laid in May or June. The nest is not commenced until the vegetation affords it ample concealment. The favourite site for the nest is amongst briars and brambles, less frequently near the top of a thick hedge or in a gorse-bush. It is nothing like so deep as that of the Common Whitethroat, but is equally slight and flimsy-looking, a mere net through which the eggs may often be readily perceived. It is made chiefly of fine round dry grass-stalks, skilfully interwoven with the surrounding twigs, and often bound together with cocoons and roots, and lined with a little horse-hair. The nest much more closely resembles that of the Garden Warbler and the Blackcap, than that of the Common Whitethroat, its shallowness being its chief distinguishing characteristic. We have frequently noticed, both in the present species and the Blackcap, that nest after nest will be commenced and left unfinished, deserted for no apparent reason, just as is often the case with the Wren. The eggs of the Lesser Whitethroat are from four to six in number, pure white or pale buff in ground-colour, blotched and spotted with various shades of olive-brown and grey. As usual most of the spots are round the large end of the egg. In general appearance they resemble those of the Garden Warbler rather than those of the Common Whitethroat. This White- 
throat rears one brood only in the year. The hen is a very close sitter, and when driven from the nest is soon joined by her mate, the two birds then flitting uneasily to and fro amongst the cover, uttering harsh notes of remonstrance.

The food of the Lesser Whitethroat is chiefly composed of insects and their larvæ; but later on in the summer this fare is varied with fruit of various kinds, berries, and even green peas. The migration south is undertaken in September, but laggards have not unfrequently been noticed in October, and odd birds have been found in this country even as late as November.

The Lesser Whitethroat is a very plain-looking little bird, having the general colour of the upper parts brownish-grey, tinged with brown on the back and ear-coverts. The wings and tail are brown, the outermost feathers of the latter being tipped with white. The general colour of the under parts is silvery-white, with an almost imperceptible brown shade on the breast and flanks. The axillaries and under wing-coverts are white. The female closely resembles the male in colour; both sexes are about five inches in total length. 




\section{THE WILLOW WARBLER}

\section{PhyllosCopUS TROCHILUS}

OF all the Warbler band that visit the British Islands each recurring spring the Willow Warbler is not only the best known, but the most widely distributed, and, we were going to add, the greatest popular favourite too. With the exception of the remote and inhospitable Orkney and Shetland Islands, together with some of the Hebrides, the Willow Warbler is found during spring and summer throughout Great Britain and Ireland, in all areas suited to its requirements. It is a species of equally wide range in continental districts, being a summer visitor to most parts of Europe from the Mediterranean nearly to the Arctic Ocean. Its summer range also includes the extreme north of Africa. In Asia it ranges equally far north, and has been met with as far east as the valley of the Yenesay. Its winter range includes Persia, Palestine, Asia Minor, Greece, Turkey, Sicily, the south of France, and Spain ; whilst in Africa it extends to an undeter- 
mined area of the Inter-Tropical Realm. Throughout this vast area it everywhere appears to be an exceptionally common bird.

The Willow Warbler is one of the earliest migrants to reach our shores in spring, and this fact in itself is one that endears the bird to us and makes it an object of special admiration. We notice the charming fairy-like little creature back in its old haunts very often during the first week of April, especially in the southern counties of England-in the very vanguard of the advancing army of migrant birds, almost simultaneously with the Wheatear, and the Chiffchaff. It is a little later in the northern districts; but during six years' observation of its arrival in South Devon we find the dates to vary from the 7 th to the I 5 th of April. The Willow Warbler may be heard and seen almost everywhere, from the suburban garden, the London park, or the town pleasure-ground, to the moors and upland wilds. It, however, prefers hedges, gardens, plantations and orchards, to woods, but is not averse to trees as well as the lower kinds of vegetation. Another thing that renders the Willow Warbler so attractive is its fearless ways, its habit of courting notice. It is no skulking creature like the Blackcap or Garden IVarbler; it seems to invite observation, and is one of the most trustful and least suspicious of all our smaller wild birds. How can we describe the feeling of pleasure we experience at seeing the 




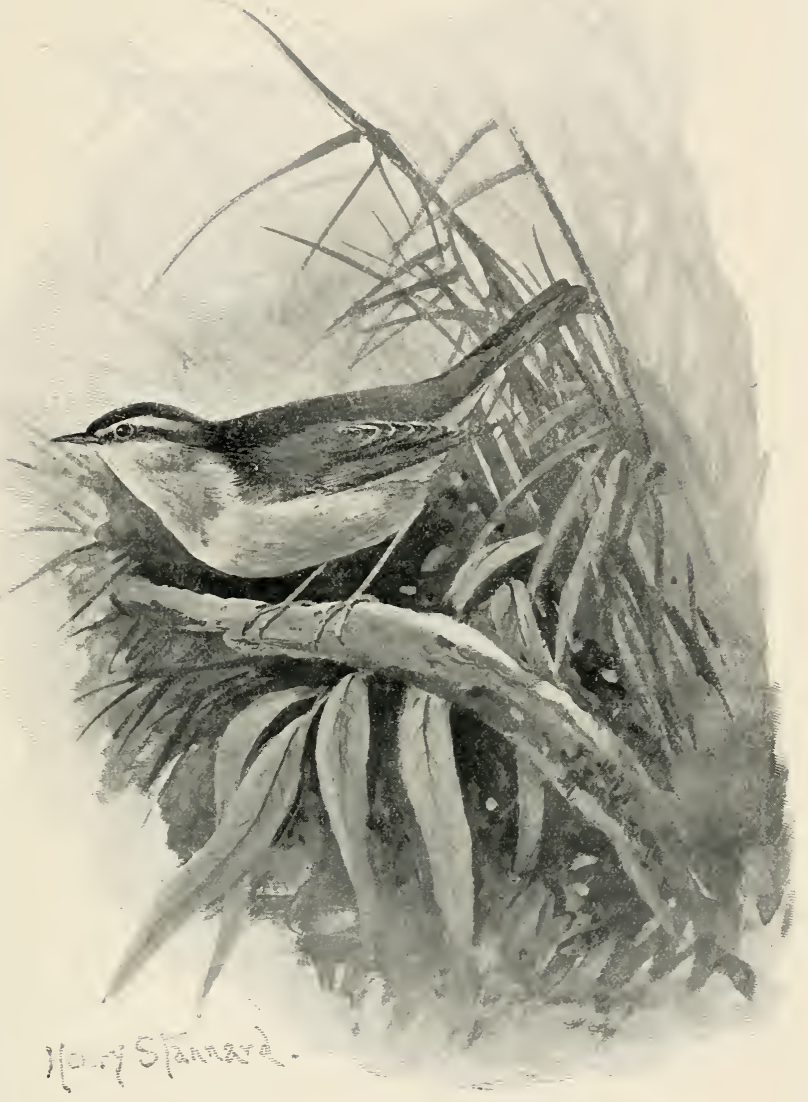

WILLOW WARBLER 

Willow Warbler for the first time in spring! There it is once more, just the same as in the many years that have come and gone, trustfully flitting from branch to branch in the still leafless trees, or mayhap amongst the fragrant apple and pear blossoms in the hoary old orchard, where we have noted its arrival for more seasons than we care to recall. Silently it searches about in quest of food, or every now and then pauses and breaks out into that song which captivates our hearts with its simple sweetness. Day by day we watch its familiar ways, and yet they never bore us; time and again we can listen to its plaintive call-note, or its witching song, and yet they are ever attractive. By the hour together we frankly confess we can watch the actions of this little Warbler without feeling one jot of weariness. Its ways are so engaging, its appearance so delicately trim and neat, as it flits about in Tit-like quest of food. Its exceeding trustfulness is one of the secrets of its attractiveness, for at arm's-length it will search the branches for food without the least show of fear. Every now and then the bird will start into the air in chase of an insect, or perhaps flutter at the extremity of a branch to search the very outermost leaves. The call-note of this species is inexpressibly soft and sweet, a double piping cry which no words can describe.

The Willow Warbler is not only a sweet singer but a most persistent one. There is nothing 
particularly striking in the little refrain, the few notes being uttered in a very attractive descending scale; but when the birds are singing in all directions, first one and then another, here, there and everywhere, the effect is charming in the highest degree. It is a little song, plaintive yet soothing in the extreme, soft and rich in tone, commencing with a few low and sweet notes, which gradually become louder and richer, and then finally die away in strains so low that they are scarcely audible a few yards away. This song is sometimes uttered whilst the bird is flying, especially in spring, or even when hopping from branch to branch. None of our song birds sing more persistently all the spring and early summer; but in July and August this song becomes less frequent, is chiefly heard at dawn, and by the end of the latter month dies away in the annual moult. It is regained, however, after the new dress is assumed, in all its former beauty, a fact which we have not remarked in any other migratory Warbler, if we except the Chiffchaff, but that bird's note scarcely attains the dignity of a song.

Whether the Willow Warbler pairs for life or not, we are unable exactly to say, but there is some evidence to suggest that the same spots are visited for nesting purposes year by year. The cosy little nest of this species is usually made upon the ground, amongst the luxuriant herbage on a bank by preference, but many other sites are selected. We 


have seen many nests placed amongst the tall meadow grass of the hay-fields; whilst the shelter of a low bush or a cluster of briars, tangled grass and brambles is not unfrequently selected. Very rarely it is placed above the ground, amongst ivy or the suckers growing at the foot of a tree. In shape the nest is semi-domed, or perhaps a better description of it is that of a moderately deep narrow nest placed on its side. It is more open than that of the Chiffchaff, and is somewhat loosely put together, outwardly made of dry grass, leaves, roots, and scraps of moss, and copiously lined with feathers and a little hair. We have counted as many as two hundred feathers in the lining of a single nest. The parent birds are very wary in conveying the materials, and may often be watched for a long time with a feather in their bill hopping restlessly about, tiring out all but the most persistent patience. The eggs range from four or five to as many as eight, and are generally pure white in ground-colour, blotched and freckled with pale reddish-brown. But one brood appears to be reared in the year, and the eggs for this are laid even as early as the end of April or as late as June.

The food of the Willow Warbler from the bird's arrival until July is principally composed of insects and larvæ, but in the later summer months when the fruit is ripe this species subsists largely upon that product of the garden. The return migration of this 
species begins at the latter end of August and lasts through September into October, whilst stragglers have been met with as late as November.

The Willow Warbler has the general colour of the upper parts olive-green; there is an ill-defined pale yellow eye-stripe; the wings and tail are brown. The general colour of the under parts is yellowishwhite, shading into buff on the breast and flanks. The axillaries, under wing-coverts and thighs are yellow. The newly moulted dress is much more yellow in tinge. The female resembles the male in colour, and the total length of the bird is five inches.

The Wood Warbler (Phylloscopus sibilatrix) and the Chiffchaff (Phylloscopus collybita or rufa) are both well-known summer visitors to our islands, but as their rocal powers are limited it has not been deemed necessary to treat them in a detailed manner in the present volume. 


\section{THE GOLDCREST}

\section{REGULUS CRISTATUS}

As questions of classification do not come within the scope of the present work, we need have no hesitation in placing the present bird in such close proximity with the Warblers, with which birds it has much in common, although by many authorities it is included with the Tits. After all there is something very Willow Warbler-like in its habits, appearance, and organization, so with the Warblers it shall stay for our present purpose. Unlike all the other species which we have described hitherto, the Goldcrest is a resident in the British Islands. It should, however, be remarked that this species visits our area, often in vast numbers, from continental Europe every autumn, but the individuals that breed with us appear to be sedentary. The Goldcrest is found practically throughout the British Islands wherever there are suitable haunts to shelter it, and these appear only to be wanting in the Outer Hebrides, the Orkneys, and the Shetlands. Outside 
these limits this bird has a very extensive range, being found, subject to certain slight modifications, from Europe to Japan. The typical form is found throughout Europe in all suitable localities, from the Arctic Circle southwards. The Asiatic birds present some slight differences, but scarcely of a specific value. There is no reliable evidence to show that this species has ever occurred in Africa, although it is said to pass Malta on migration.

The Goldcrest is most frequently found in shrubberies, plantations, gardens, and parks where larch, fir, and yew trees are plentiful. It may of course often be observed amongst deciduous vegetation, in woods, hedges, coppices and the like, but trees of an evergreen character are always its delight. There is much in the habits of this engaging little species - the smallest British bird-to remind us of the ways of Tits and Willow WVarblers. Indeed the Goldcrest is very fond of consorting with the firstnamed birds, especially with Coal Tits, and during the autumn and winter months. We remark the same method of searching for food as in the Willow Warbler, the restless hopping and flitting here and there, the darting into the air in chase of passing insects, the pause every now and then for the utterance of song. Although neither shy nor skulking it goes so quietly about its avocations as to be often overlooked. Very often the first sign of its presence is the wonderfully high-pitched call-note 




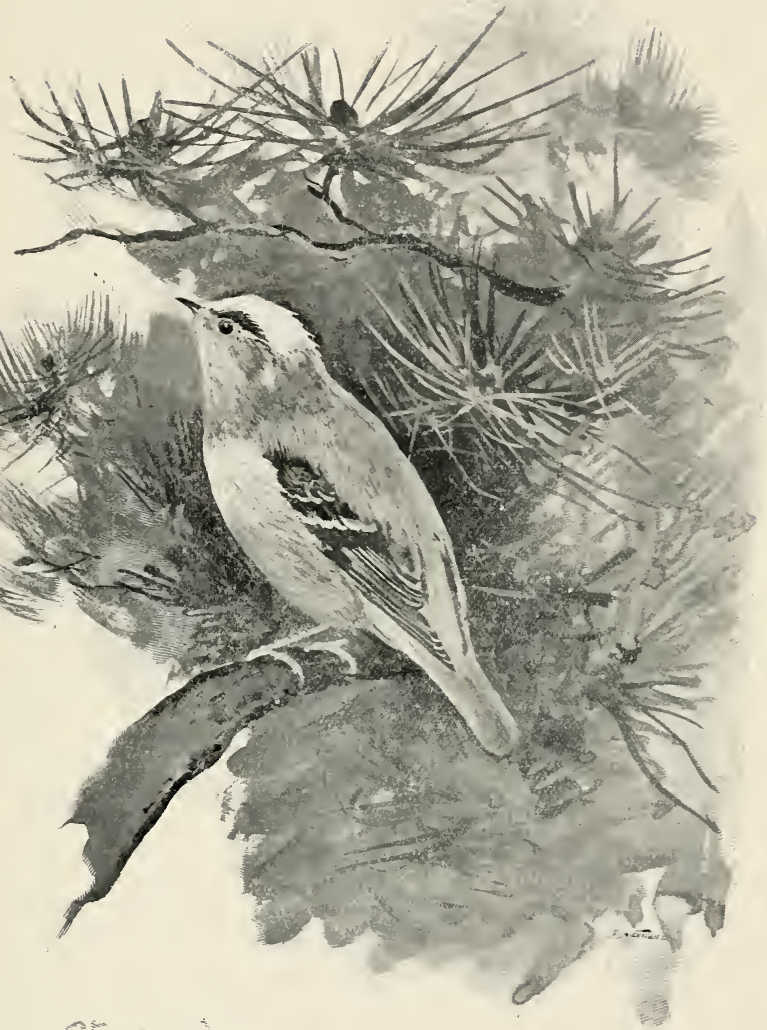

Henry sfandiayd

GOLD CKRT 

-so bat-like and acute as to be inaudible to some ears, and located with the greatest difficulty. As likely as not the tiny bird is discovered much nearer than was expected. It is a most trustful little creature, and may be watched searching the twigs and leaves in a variety of grotesque attitudes, without exhibiting the slightest fear of man. Its activity is great, and it soon passes on its way, flitting from tree to tree in a wavering manner, followed by or following its companions, now lost for the moment, then appearing again where we might least have expected it. This engaging bird is readily identified by its glowing orange or lemon-coloured crest (the latter tint being peculiar to the female), and this striking decoration gleams with great brilliance in the sunlight, rendering mistake impossible. In autumn the Goldcrest becomes to a certain extent gregarious; but we think the resident individuals are not so socially inclined as those other ones of this species that come in flocks from over the sea. These autumnal flights of Coldcrests do not appear to reach South Devon, and here we do not remark such gatherings as we were wont to do long years ago in the woods of Yorkshire. The bird is fairly common here, but it is generally seen in pairs, save in the summer, when the broods and their parents are wandering about in company.

The Goldcrest is a songster of considerable merit, but unfortunately he sings in too low a strain. His 
voice is exceptionally sweet and clear, but the song is so softly poured forth that it generally escapes notice altogether. It is of about the same duration as that of the Willow Warbler, but cannot be heard at a quarter the distance. Neither is the bird a very persistent chorister. The song is perhaps heard most frequently in spring, but after ceasing in the moulting season it is often regained in autumn in all its simple beauty. It is in fact a song that must be searched for; it is in nowise obtrusive; but the reader may rest assured that when he does succeed in fairly hearing it he will not be disappointed.

The Goldcrest breeds amongst the evergreen trees it loves so much to frequent. Its nesting season is in April and May. It is probable that this bird pairs for life, although a new nest appears to be made each season, but the same little cluster of trees will be resorted to for years in succession. It is also worthy of remark that even a small plantation will often accommodate several pairs of birds. The nest is usually slung or suspended hammock-wise under the extremity of a drooping fir or yew branch. It is said sometimes to be placed upon the branch, but this must be a very exceptional circumstance. It is nearly globular in form, and is a charming example of avine architecture, being composed externally of moss, spiders' webs, hairs, and a few bits of lichen, well felted together, and warmly lined 
with feathers. The foliage surrounding it is skilfully interwoven, so that the whole appears nothing but an unusually dense clump of twigs and leaves. The eggs are usually from five to eight in number, but ten have been found. They are pale reddishwhite in ground-colour, sometimes pure white, minutely speckled with brownish-red, chiefly on the larger end. Both eggs and nest are unique so far as British birds are concerned, and cannot possibly be confused with those of any other species. The Goldcrest is shy and retiring during the nesting season, and a close sitter, but the tiny moss-built home is easily discovered by those who know where to seek it. But one brood is reared in the season, and young and old keep in company after the former leave the nest.

The food of the Goldcrest is chiefly composed of insects and their larvæ, but small seeds, notably of the birch and heather, and soft berries, such as those of the yew, are also eaten. In districts which come within the limits of the migrations of this bird its annual wanderings are very interesting. The bird is well known along the shores of the wild North Sea and to the men who sail its waters. Sometimes vast swarms of this tiny migrant are met with far out to sea, and they have been known to cluster on the rigging of ships, and to visit lighthouses and light-vessels in astonishing numbers. For further particulars relating to the migrations of the Gold- 
crest we may refer the reader to the present writer's works on the subject.

The Gollcrest has the general colour of the upper parts olive-green, strongly suffused with yellow in the newly-moulted plumage. Along each side of the forehead are two black streaks which enclose the crest of bright orange-yellow. The wings and tail are brown, each quill feather with a greenish margin, and the greater and median wing-coverts are tipped with white, thus forming two conspicuous white bars across the wings. The under parts are nearly uniform greyish-brown. The female closely resembles the male in colour, but the crest is yellower, and the plumage generally less brilliant. The young birds in first plumage have no trace of the yellow crest. The total length of this diminutive species is not more than three and a half inches. 




\section{THE SEDGE WARBLER}

\section{ACrocephalus PHRAGMITIS}

IT seems scarcely credible now-a-days that such a common bird as the Sedge Warbler was so little known in Gilbert White's day that the old Hampshire naturalist actually confused it with the Reed Warbler. But ornithology like other sciences is a progressive one, and doubtless the ornithologists of a future age will regard many of the achievements of present day students with as much astonishment as we do those of a past generation of naturalists. The Sedge Warbler is another very common and widely dispersed member of the present group, and appears to visit the greater part of the British Islands in spring and summer for the purposes of reproduction. In some parts, especially in the southern counties, it literally swarms, but in the more northern districts it becomes not only more local but decidedly rarer. We do not find it breeding in the Shetlands, or the Outer Hebrides, although it may do so in the Orkneys, and certainly does so in Skye. In Ireland 
it appears to be equally widely distributed. Outside the British Islands its range is very wide, extending over the greater part of Europe and Asia at least as far east as the valley of the Yenesay, where Seebohm remarked the bird's abundance. Its northern range in the west reaches almost to the limits of continental land, but in the east does not appear to extend much above the Arctic Circle. In South Europe and North Africa the bird appears to be a passing migrant chiefly, although it may possibly breed sparingly in Algeria, the south of France, Italy and Greece. It certainly breeds in Palestine, and is said to do so in Corfu and Crete. Absent apparently from Persia, it visits North-western Turkestan, although its eastern limits in Asia are not yet determined. The winter range of this species extends from Asia Minor to some unknown area in the Ethiopian portion of the Inter-Tropical Realm.

The Sedge Warbler is a somewhat late migrant to our area, usually not appearing, even in southern localities, before the last ten days of April, and in the northern and more remote western ones not until the beginning of May. Although this bird belongs to the reed or marsh WVarbler group, its haunts are by no means çonfined to swampy localities. Its favourite resorts, so far as may be estimated by the number of individuals, are osier- and reed-beds where the ground is more swampy than covered with water, tangled thickets near pools and marshy spinnevs by 


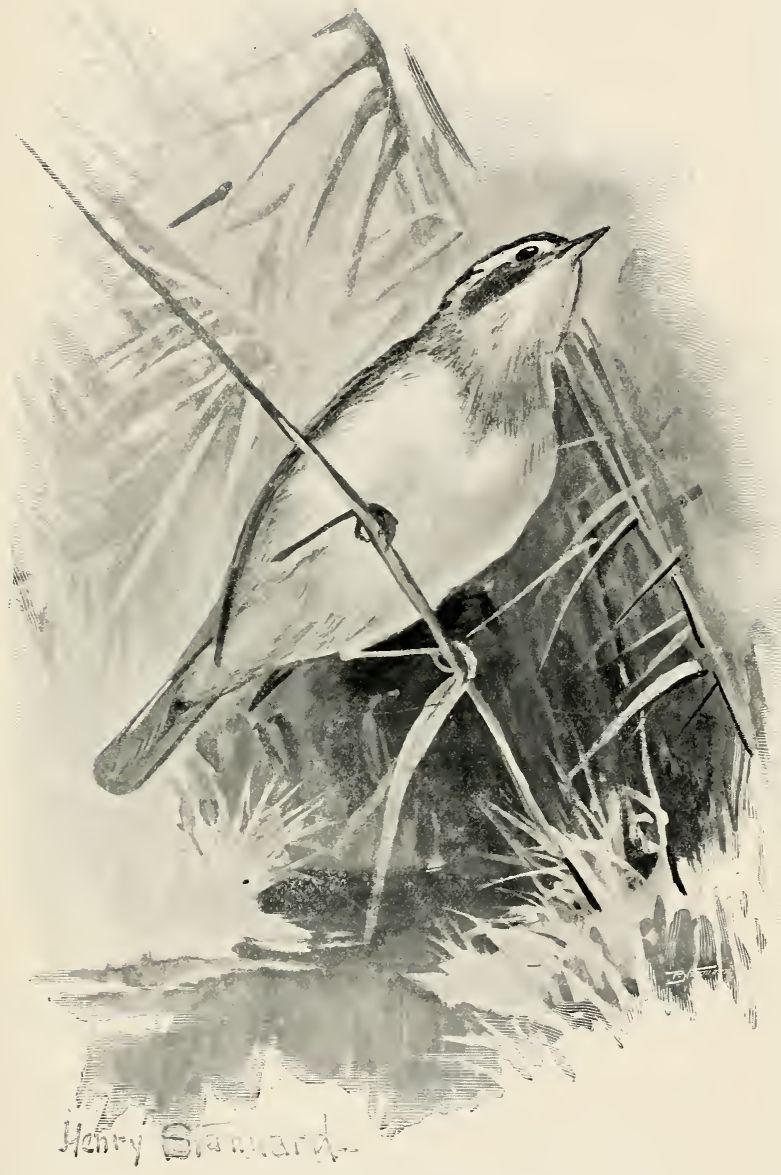

SEuge W ARBLER 



the river-side. It may, however, often be observed in dense hedges far from water, and weed- and briarchoked ditches. We cannot call the Sedge Warbler a particularly shy or retiring species. If alarmed it is skulking enough, but if not disturbed it will fearlessly go its way in full view of the observer, and may very frequently be seen clinging to the topmost point of a reed or bush, or flying from one side of a stream to the other with no attempt at concealment. Sedge Warblers are very quarrelsome birds, especially just after their arrival, and before each pair has comfortably settled down into a chosen spot for the summer. Even then the birds resent intrusion, and no matter how abundant they may be, each pair are attached to a certain beat from which they are ever ready to drive off trespassers. Before the vegetation is full grown the birds may be watched hurrying about more like mice than birds, and the celerity of their movements is very noteworthy.

The Sedge Warbler is the Song Thrush of the swamps; and his song is even more varied than that of that bird, much more persistently uttered, and far longer in duration. One might fancy that the little brown singer, hidden away amongst the iris and osiers, had borrowed a few notes from every other songster of the grove, and was trying them over in a deliciously sweet and rambling manner. For as many as ten minutes without a pause, he will continue to utter his varied strains, now harsh, now 
sweet, now loud and clear, now low and plaintive. Sometimes a few notes are warbled in splendid tune, but the sweeter tones are broken and interrupted by the introduction of chirps like those of a House Sparrow, croaks like those of a frog, or a long string of chattering cries, which at once recalls the song of the Wren. Many of the sweeter notes resemble those of the Whitethroat, the Goldfinch, or even the rapturous voice of the tame Canary. When once fairly settled down to song the Sedge Warbler is not easily stopped. He will continue to run through the entire range of his song in spite of the noise of advancing steps, or even of the stones thrown into the thickets to scare him. If compelled to change his perch, he often does so singing as he flies; or, for a brief instant the song is hushed, and then breaks out anew in some more secluded corner of his haunt. As is so characteristic of the Song Thrush, the Sedge IVarbler frequently repeats a note, or a series of notes, several times in succession, before passing into another variation of his everchanging song. The Sedge Warbler is a most persistent night singer; and when several birds are singing in concert, as they often do in districts where the species is common, the effect is extremely beautiful to the ear during darkness, when surrounding objects are hidden in gloom, and there is nothing to disturb our undivided attention. All night long the Sedge IVarblers sing almost incessantly, but as 
the dawn arrives a marked falling-off takes place. No one unacquainted with the song of this species can ever realize its beauty or its infinite variety, from a written description; it must be heard to be appreciated. Our observations of this species show that it does not sing much during the hottest part of the day, neither does it sing during cold windy weather, unless disturbed. The song is most persistently uttered at night, and is particularly charming about the middle of May-on the fine, warm, moonlight nights of that glorious month of flowers and foliage. Sometimes the bird may be heard singing high up in trees near its swampy haunts, and occasionally flies from the topmost branches to the reeds below, warbling all the way. In far more cases than we have here space to specialize has the song of the Sedge IVarbler been attributed to the Nightingale; and this generally happens in districts where the latter bird is either rare or entirely absent - a confusion which has led to much popular error in the distribution of the more local species. A person familiar with the song of both birds can, of course, never fall into such an error, for the notes of the Nightingale are incomparably the sweetest. The song of the Sedge Warbler is continued well on the summer, but falls off as soon as the eggs are hatched, and ceases prior to the moult, not to be regained until the following year.

The Sedge Warbler pairs soon after its arrival, if 
indeed it does not mate for life, as certain districts are visited annually for nesting purposes. The nest is made in willow-bushes, amongst dense thickets of briar and bramble, or close hedges, or amongst the coarse grass and reeds at the foot of the osiers, even on the pollarded stumps themselves, but never suspended to the reeds. It is small and loosely put together, made of dry grass, bits of moss and sedge, and lined with a little horse-hair or vegetable down, and sometimes a feather or two. The eggs are five or six in number, bluish-white in ground-colour, more or less thickly clouded and mottled with buffishbrown or greyish-brown, and often streaked with a few pencillings of very dark brown. The parent bird sits closely, and does little to betray the whereabouts of the nest. But one brood is reared in the year, and young birds and their parents appear to keep in company and to migrate together.

The food of this Warbler is chiefly composed of insects and their larvæ, but evidence is not wanting that this fare is varied during the latter months of its sojourn in our islands, with fruit and certain soft berries. Sedge Warblers are certainly migrating southwards in August, but September is the usual time of departure from us, and odd birds may occasionally be met with in October.

The Sedge Warbler has the general colour of the upper parts russet-brown, each feather (except those on the rump) having a darker centre, which gives the 


bird a somewhat spotted appearance. Above the eye is a buffish-white stripe. The under parts are buffish-white shading into pale buff on the breast and flanks. The female closely resembles the male in colour. This Warbler is about five inches in length. 


\section{THE REED WARBLER}

Acrocephalus streperus.

The Reed Warbler is essentially an English species, by no means uncommon in the southern, midland, and eastern counties, and in many parts of Wales. It is, however, we believe, entirely absent from Devon and Cornwall. It becomes rare and local in Lancashire and Cumberland, and in Yorkshire is only known to breed as far north as Ripon, but is common at Hornsea Mere. It may possibly breed regularly in the valley of the Tyne; but its summer range does not extend to Scotland or to Ireland. Outside the British area the Reed Warbler has a somewhat extensive range, breeding throughout Europe south of lat. $5^{\circ}$, and eastwards through Asia Minor, Palestine, Persia, Turkestan, Southwestern Siberia, and Baluchistan. Its winter range is apparently restricted to the Mediterranean Basin and the Ethiopian portion of the Inter-Tropical Realm.

The Reed Warbler must be classed amongst the 68 


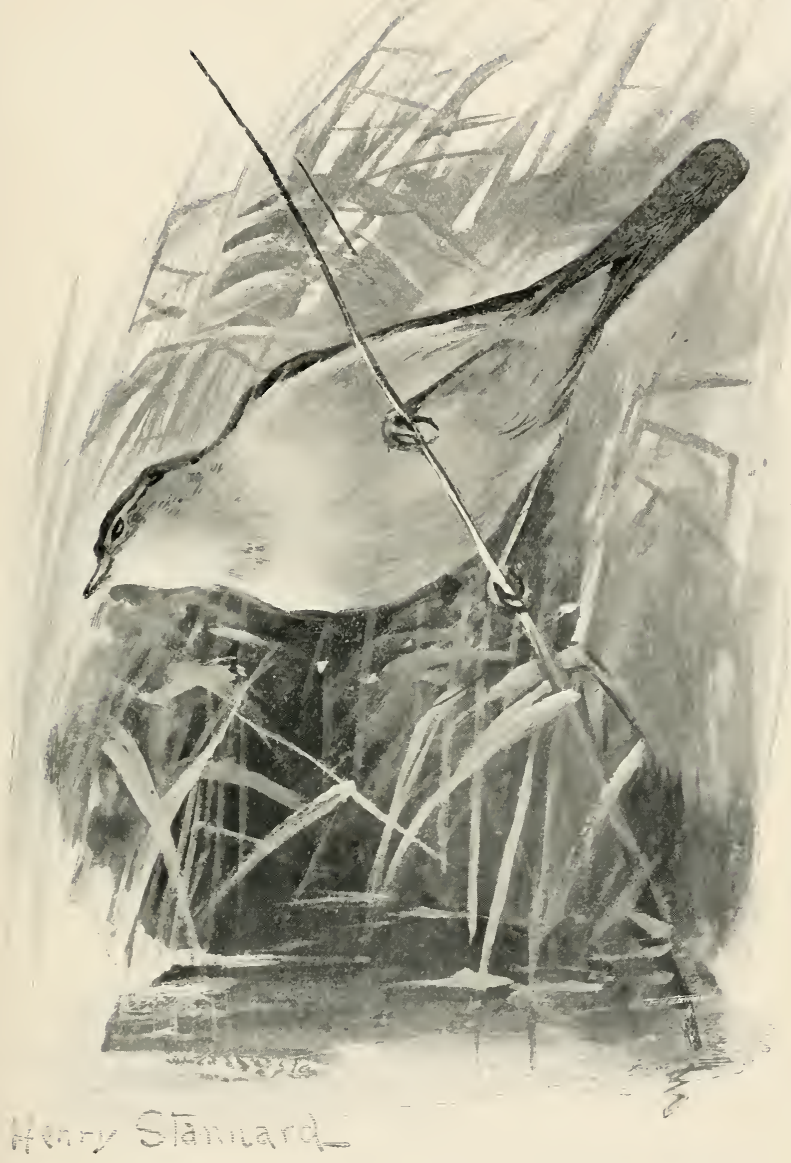

REED WARBLER 

later of our summer migrants, not reaching the British area before the end of April or the beginning of May. Owing to its partiality for certain haunts it is a somewhat local species, and what is even more remarkable, is its absence from many apparently suitable districts. But this, we are convinced, is more due to the law which governs the dispersal of species, than to any capriciousness upon the part of the bird itself. The favourite resorts of this Warbler are reed-beds, and the reed-and willowfringed banks of slow-running rivers, and stagnant dykes and pools. Brushwood and thickets by the water-side, and less frequently localities affording plenty of cover, at some distance from water, may also be given as its haunts. A casual observer might be led to suppose that the Reed Warbler is gregarious, but such is not the case; although many pairs may be met with in a comparatively small area, each keeps to certain limits and resents intrusion. The Reed Warbler is more retiring in its habits than the Sed re Warbler, and is not so readily observed, skulking persistently amongst the thickets and the reeds, eluding observation by its mouse-like actions, and only betraying its whereabouts by a harsh scolding note, as if of remonstrance, by a snatch of song, or by the vibiation of a reed or twig as it glides from stem to stem with marvellous celerity. The general habits of the Reed Warbler are almost exactly the same as those of the Sedge 
Warbler, with this difference, that the latter species is not so shy and skulking in its movements. Reed Warblers may often be seen amongst the branches of moderately high trees by the water-side; they have the same habit of flitting across the open spaces from one cover to another; they are similarly nocturnal, and possess the same restless activity.

The Reed Warbler is another very persistent singer, and during the early summer his song is one of the most characteristic features of the reed-beds. The song is not unlike that of the Sedge IVarbler, a chattering melody, in a lower tone, but what it lacks in loudness it certainly gains in gentle sweetness. We should describe it as being more monotonous than the Sedge Warbler's, and there is perhaps a more frequent introduction of harsh notes. The bird habitually sings at night, commencing in the warm soft twilight of the early summer evenings, and warbling almost incessantly until the sun reappears above the eastern horizon. Cold sunless days and windy nights almost invariably silence this little reed bird's voice. It continues in song until the eggs are hatched, but is by far the most musical during the first few weeks of its sojourn with us. This species also sings as it flies, and is one which is not readily silenced when once fairly in voice.

The birds appear to pair after their arrival in the summer quarters, but as the same reed-beds are 


visited annually for breeding purposes, one might almost be led to think that they mate for life. Be this as it may, the birds are very quarrelsome and noisily pugnacious until each pair has settled down into its summer quarters, but the time of nest-building depends a good deal on the state of the weather. If warm and genial, operations soon begin, but cold dull weather seems to retard them. The eggs are laid during May and June. The nest of this Warbler is either made amongst the reeds, in the slender branches of willows and alders overhanging the water, or less frequently in a thick hedge by the river-side. It is made at varying heights from the ground, or rather water, sometimes being within a few inches of the surface, at other times several feet. When made amongst the reeds it is suspended between three or four stems, whilst those placed in branches are slung from several slender twigs, the material being woven round each in turn. The nest is a deep well-made structure-quite a different type of architecture altogether from that of the typical Warblers-composed of dry sedge and grass, the ribbon-like leaves of the reeds, roots, bits of moss, wool, and vegetable down, lined with finer down, sometimes a feather or two and a little hair. In some cases the nest is very elongated, almost funnel-shaped, with a considerable foundation below the cavity containing the eggs; others are more cup-shaped, and these are made with much less 
material. The four or five eggs are pale greenishblue-almost white in some cases - in ground-colour, spotted and blotched with olive-brown, freckled and sometimes streaked with darker brown, and with underlying markings of grey or paler brown. The female sits the most, and both birds become excieed and utter harsh scolding notes if disturbed at the nest. But one brood is reared in the year; if the first lot of eggs be taken, a new nest will be made and another clutch produced.

The food of the Reed Warbler is chiefiy composed of insects and their larvæ; many imagos are caught whilst on the wing. In the later summer months there seems to be little doubt that small soft fruits and berries are also eaten. This Warbler is a comparatively early migrant in autumn, its journey south commencing towards the end of August, but many birds appear to delay their departure until the first half of September.

The Reed Warbler is a very plain-looking little bird, having the general colour of the upper parts olive-brown strongly suffused with rufous, especially on the rump and upper tail-coverts. The wings and tall are brown, the feathers with paler margins. The under parts are white, shading into buff on the breast, flanks, and under tail-coverts. The female closely resembles the male in colour, and the total length of this species is a little over five inches.

Mention might here be made of the nearly allied 
Marsh WVarbler (Acrocephalus palustris), which is one of the rarest of our summer migrants. Its song, which we have not heard, is said to be much finer than that of the Reed Warbler; but this species, so far as is at present known, is so rare and local that it scarcely merits more than passing notice in the present volume. 


\section{THE GRASSHOPPER WARBLER}

LOCUSTELLA NAVIA

Thrs interesting little species, the "Grasshopper Lark" of Pennant and Gilbert White, and the "Reel Bird" still of many country folk, is one of the most skulking of our native birds. The Grasshopper Warbler, as most modern ornithologists now designate it, is a very widely distributed species in our islands, if somewhat local, and perceptibly more abundant in some districts than others. It is a regular summer visitor to most parts of England and Wales. In Scotland, although rarer and more local, its chief resorts appear to be south of the Forth, although it is known to breed sparingly here and there at least as far north as Skye. We also find it widely distributed in Ireland, but local there, as everywhere else, and with its headquarters in the eastern and southern counties. It is a summer visitor to various parts of Central and Southern Europe (south of the Baltic), and is said to visit South-western Asia as far as the 


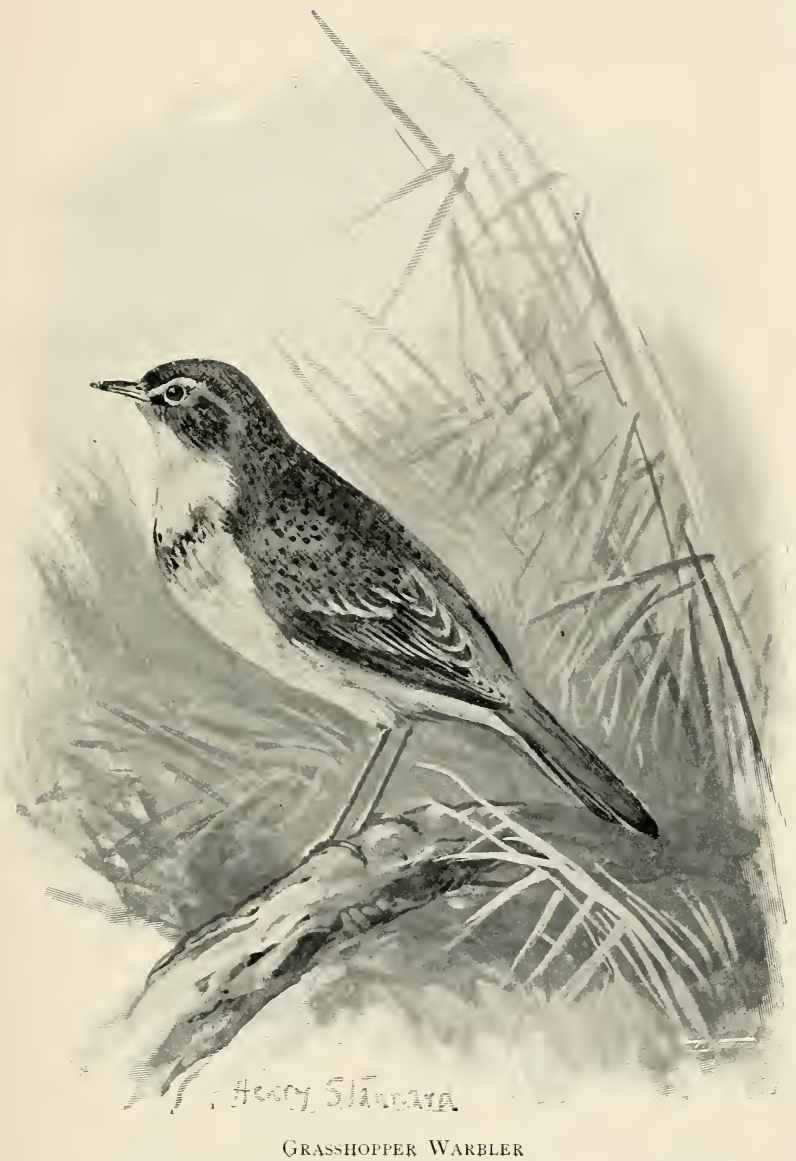





Altai mountains. Its winter quarters appear to be in the basin of the Mediterranean.

The habits of a bird so skulking and shy as the Grasshopper Warbler are difficult to describe, because they are difficult to observe. Although the bird may be absolutely common in a district, it shows itself so rarely and so transiently that ordinary observers might well be pardoned for overlooking it altogether. This Warbler is not only skulking, but it is excessively shy. We have a certain sheltered valley here in South Devonshire, whose slopes are clothed with a dense thicket of gorse ; and here in spring numbers of Grasshopper Warblers locate themselves. Upon their first arrival, which takes place during the last half of April or the beginning of May, they are sometimes very abundant, as if they had migrated in company and were resting for a short time before spreading over the surrounding country; perhaps many of the birds pass on to more northern haunts, for the species is never so common after the first week or so of its appearance. Be this as it may, it is quite an exceptional event to catch a glimpse of a bird; and we have found from long experience that the most successful way to see them was to visit their haunts very early in the morning, and to remain very quiet. The skulking little fellows would then regain confidence, or perhaps relax their wariness, and if we saw a couple of birds 
during the course of a morning's watch we felt contented-gratified that we had at least outwitted them to some extent. And even then generally all we saw was a male bird run mouse-like up some twig taller than the rest, sing for a few fleeting moments, and as suddenly drop down again. It is perfectly useless to try and flush the Grasshopper Warbler; he will seldom or never commit himself, and for hours you may follow him backwards and forwards, led on by the alluring and curious song, without once catching a glimpse of the dusky singer. The Grasshopper Warbler is by no means confined to marshy places, although it shows a strong partiality for them in some localities. Its favourite resorts are thickets, the brushwood in plantations and game coverts, matted hedge-bottoms, ditches, and the longer vegetation on commons and moors. We have frequently met with this species on the moors, miles away from woods, frequenting the tall ling and clusters of stunted thorns and brambles. If one is ever fortunate enough to drive this Warbler from the cover, its flight will be found to be desultory and apparently feeble, and is never prolonged for any great distance, the bird's one effort being to hide itself as quickly as possible.

The song of the Grasshopper Warbler once heard can never be forgotten. Not that it possesses any sweetness; its sole charm is its apparently neverending monotonousness. Of all our favourite song 
birds it stands out prominently as the most curious singer. The song is composed of one long tremulous trill, louder than the noise made by the grasshopper, but just as monotonous. This sibilant song often lasts without cessation for two or three minutes together, now sounding startlingly near, or very remote as the bird changes its position in the thick cover-loud and close when the singer is up in the branches, low and remote when down in the grass and weeds. We have often heard the song of this species likened to the sound made by a fisherman's winch when the line is running out at full speed. The song of this IVarbler may be heard at all hours of the day and night; but it becomes specially loud and continuous in the dusk of the summer's evenings. If disturbed whilst singing the bird appears to show little uneasiness, and is not readily silenced. The song may cease for a moment as the bird's retreat is approached, but it bursts out anew directly afterwards in another part of the cover; and you may chase the bird up and down for an hour or more without once getting a peep at the hidden songster. This song is heard most persistently through the early summer, but wanes after the eggs are hatcined, and ceases altogether before the moult.

The nesting season of the Grasshopper Warbler is in May and June. Although many pairs of birds may be nesting within a small area of suitable 
ground, this Warbler is neither gregarious nor sociable, and each pair have their own nook from which they drive away all intruders. The nest is either made upon the ground, or less frequently a short distance above it. It is one of the most difficult of our British nests to find, being hidden away under briars and brambles, or amongst rank long grass, at the foot of a bush, often in such dense situations that the birds approach it by a kind of "run" through the herbage. It is a somewhat compact and deep structure made of dry grass, moss, and dead leaves, and lined with finer round dry grass-stalks. Nests of this Warbler have been found amongst clover. The eggs are from four to seven in number, white, suffused with pink in groundcolour, densely sprinkled with reddish-brown and grey. On some eggs a few hair-like dark brown lines occur. These eggs are not readily confused with those of any other species. The bird, as might be expected, is a very close sitter, and leaves the nest when disturbed in a stealthy manner. But one brood appears to be reared in the year.

The food of the Grasshopper Warbler is chiefly composed of insects and larvæ, but late in the season fruits of various kinds are sought for. The migration south begins in August and is continued through the following month; but as the species is such a retiring one the exact date of departure from any given locality is not very easily determined. 


The Grasshopper Warbler has the general colour of the upper plumage olive-brown, each feather with an ill-defined dark centre: the wings and tail are dark brown, with paler brown margins to the feathers. The chin and centre of the belly are white, shading into buffish-brown on the breast, flanks, thighs, and under tail-coverts, the latter having dark centres. There is little difference in the colour of the sexes; and the total length is about five and a half inches. 

THE THRUSHES 





\section{THE THRUSHES}

The Thrushes are another somewhat hetero geneous group whose limits are by no means easily defined, and concerning which taxonomists express considerable diversity of opinion. There can be no doubt whatever that the Thrushes are closely allied to the Warblers, and also to the Flycatchers. From the former group, as has already been remarked, they differ morphologically in having a spotted nestling plumage-a fact which unquestionably indicates an inferior degree of organization, and also a strong affinity with the latter group. Within this group are included species which have very popularly been supposed to belong to the Warblers. These are the Robins, the Nightingales, the Accentors, and the Redstarts. In the present state of our knowledge it is quite impossible to give even the approximate number of species in this family; but if we restrict it to about the same limits as were assigned by Seebohm it cannot number much less than two hundred and sixty specics and 
well-defined geographical races. Species are much more sedentary in the present group than in the preceding one, although there are many which undertake migrations of varying magnitude. The Thrushes are a much more showy group than the Varblers, some of the species being remarkable for exceptional beauty. Their vocal powers are of varying degrees of merit, but amongst them must be included some of the finest of known songsters. As is usual with secondary sexual characters, great diversity even in obviously closely allied species is presented. The Thrushes (Turdus), Ouzels (Merula), Rock Thrushes (Monticola), and the Robins and Nightingales (Erithacus), are by far the finest songsters in the family, the latter perhaps claiming the foremost place. The Bluebirds (Sialia) of America, and the Chats (Saxicola), Redstarts (Ruticilla), and Stonechats (Pratincola) of the Old World are less noted vocalists. The present family is practically a cosmopolitan one, and their centre of dispersal is unquestionably the InterTropical Realm. Many of the finest songsters in the present family are unfortunately non-indigenous to the British Islands, or only occur therein as rare and abnormal migrants. Of these absentees it may prove of interest to the reader to mention the following-all exceptionally famous for their vocal attainments. Perhaps none of the typical Thrushes excel the sweet singers of our own land; there are 
many foreign species in this group justly famed for their music, yet so far as we can gather our native songsters lose nothing by comparison with them. One very noteworthy characteristic of the melody of many of the typical Thrushes is the curious repetition of the notes, most pronounced perhaps in our own Song Thrush. The American "Robin" (Turdus migratorius) is also especially remarkable in this respect, repeating each series of notes many times in succession. The Rufous Thrush (Turdus rufiventris) of South America is also another singer of exceptional merit ; with the same peculiarity of repeating note after note in quick succession. Some of the non-British Robins, again, are birds of surpassing song. That of the Ruby-throated Robin (Erithacus camtchatkensis) is described by Seebohm, who heard it in the valley of the Yenesay, as scarcely inferior to that of a Nightingale. Again, that of the Arctic Bluethroat (Erithacus suecica) is thus very accurately described by the same eminent authority. Upon first arriving at its summer quarters in the high north, the song is uttered in a very subdued strain, but the rapid advent of summer appears soon to improve the bird's voice, and it becomes louder and longer until almost rivalling that of the Nightingale in sweetness. Seebohm writes respecting the imitative character of the song: "Often we were puzzled by the mimicry of this fine songster. On one occasion, after listening 
for some time to the well-known musical cry of the Terek Sandpiper, tirr-r-r-whui, blended with the songs of scores of other birds, on approaching we saw our little friend perched high in a willow-bush, with throat distended, bill rapidly vibrating, and uttering the tirr-r-r-whui with perfect distinctness. We have heard the Blue-throated Warbler also imitate, amongst other bird-voices, the trilling first notes of the Wood Sandpiper, or the full rich song of the Redwing. Sometimes he runs these together in such a way as to form a perfect medley of birdmusic, defying one who is not watching to say whether or not the whole bird-population of that part of the forest are equally engaged in the concert at the same time." Other fine singers are the Rock Thrushes, birds which appear to be intermediate between the Chats and the Thrushes. By some authorities the Rock Thrush (Monticola saxatilis) is declared to be the finest songster in Europe. It is certainly in very high request as a cage-bird, and it is said that birds of exceptional vocal merit command very high prices. The song is perhaps louder than that of the Blackcap, and combines the rich flutelike tones of the Blackbird with the pleasing variety of that of the Song Thrush. The Blue Rock Thrush (Monticola cyanea) is an equally fascinating songster. Its wild, rich, varied song sounds particularly beautiful on the stony mountain-sides, and is certainly one of the things that help the most 


to break the monotony of the wilderness. The Bluebirds of the New World are justly famed for their vocal powers, the common and best known species (Sialia sialis) possessing a soft melodious song of bewitching beauty. The males of this species are much addicted to early morning song, and have the same habit as the Rock Thrushes of the Old World, of singing during flight. The Bluebird has the additional attraction of being a perennial songster; and it is said that at no time of the year is its voice heard to greater advantage than on a warm sunny winter's day. In the Bluebirds and the Rock Thrushes we have certainly a most interesting exception to the almost universal rule that music is not associated with great brilliancy of plumage. In both these groups birds of exceptional brilliancy occur, the Bluebird especially being a species of the brightest tints. The music of the extra British Chats and Redstarts calls for no exceptional mention. The birds in the present group are perhaps more persistent vocalists than the Warblers, for many of the species regain their song after the autumn moult, and sing more or less frequently throughout the colder months. Indeed in some cases the song is peculiar to the stormiest seasons of the year. The present group is fairly well represented in the British Islands, not only as regards number of species, but quality of voice. These we now propose to deal with in detail. 


\section{THE NIGHTINGALE}

\section{ERITIIACUS LUSCINIA}

The transition from the Warblers to the Thrushes appears to be most naturally made by way of the Nightingales and Robins, and these birds therefore claim the post of honour in the present group. Of these the tuneful Nightingale is justly famed the most, for of all avine singers it is undoubtedly one of the very sweetest. Although somewhat local the Nightingale cannot be considered a rare bird, whilst in some districts it swarms to such an extent as practically to constitute itself a nuisance to those unfortunate people who sleep lightly, or are easily disturbed in their slumbers. The Nightingale is essentially an "English" bird, for it is only known to breed in one or two parts of Wales, and is entirely unknown in Scotland and Ireland. Its range even in England is peculiarly restricted, and is for the most part confined to the area of the plains, from Somerset to Kent, northwards to Yorkshire. South of Scandinavia 


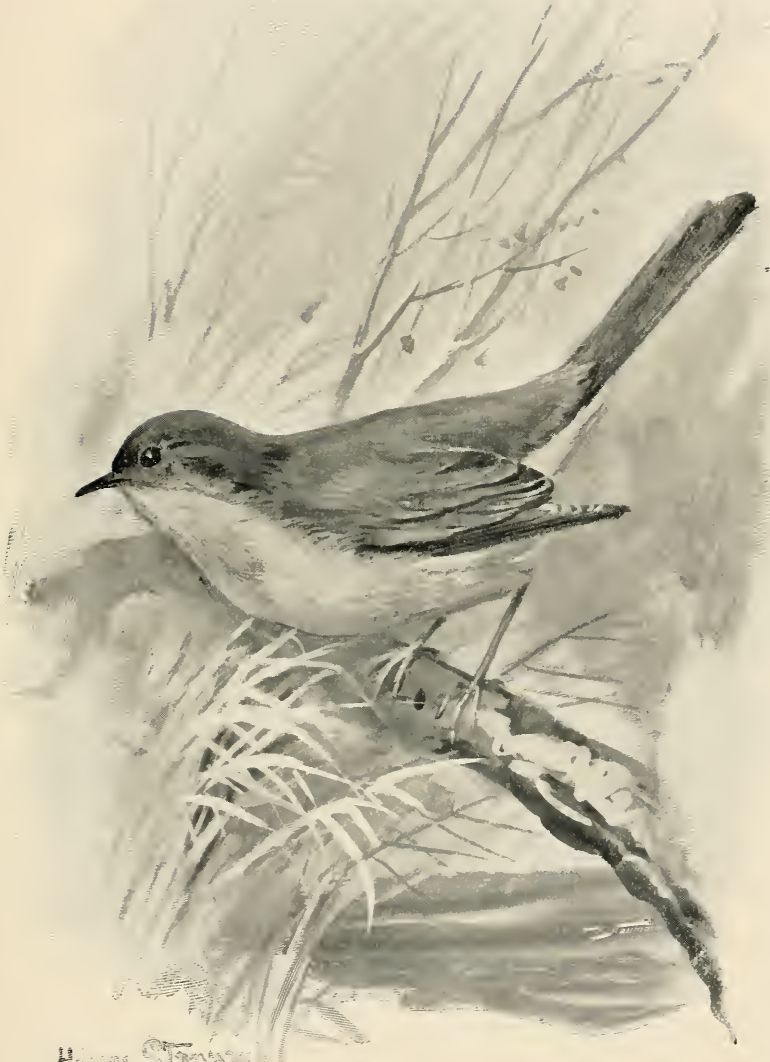

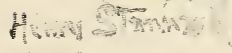

Nightingale 

and west of Russia the present species is a summer visitor to Europe. It breeds somewhat sparingly in North Africa, and is said to do so in Palestine. Its winter quarters are in the Ethiopian portion of the Inter-Tropical Realm.

The Nightingale is neither a very early migrant to the British Islands, nor a very late one, usually arriving about the middle of April in the southern counties and about a week or ten days later in the northern ones. The male birds are generally a few days in advance of the females, but song is not resumed until the arrival of the latter. In many of its habits, and in the haunts it frequents, the Nightingale very closely resembles the Robin. The actions of the two species are so much alike that even a casual observer must quickly perceive the birds' close affinities. In one respect, however, the Nightingale loses by comparison, it is nothing near so tame and confiding, loving more to skulk and hide amongst the dense cover, and always more fearful of observation. The favourite haunts of the Nightingale are small woods, plantations, marshy spinneys, the vicinity of hop-gardens, quiet lanes, shrubberies and old-fashioned orchards. This bird certainly shows a partiality for wet groundplaces in which food is plentiful. Nightingales appear to migrate to their breeding-grounds in companies; and it is a fact of frequent occurrence to find certain small plantations full of newly arrived 
birds which may remain for days before they scatter over the surrounding district to their particular nesting-places. $\mathrm{IV}^{\prime} \mathrm{e}$ have repeatedly remarked this in the Kentish coppices, and as the males are at this time very musical, the least pretext starting rival birds into song, the effect is very charming. The Nightingale has the same abrupt way as the Robin of hopping out from the cover on to a bare spot with a flick of his wings and tail, and pausing for a moment before seeking amongst the fallen leaves or the short grass for food. Although fond of concealing itself in the dense vegetation of its haunts, the Nightingale is not a tree-haunting species, and it also spends a good deal of time upon the ground. It is shy and wary, and has a habit of slipping very quietly off into the cover when alarmed, its chestnut tail outspread during flight and looking very conspicuous as the bird flits before us. Its alarm-note is a decidedly harsh and unmusical croak, but the call-note is a very plaintive weet, and it also has a peculiar habit of snapping the mandibles together if much disturbed.

To most people the chief point of interest connected with the Nightingale is its song. The music of no other bird is surrounded with such romantic glamour, its voice has become inseparably associated with our literature, and has been a poet's theme for. ages uncounted. Possibly it does not merit the wild 


praises that have so lavishly been bestowed upon it, because all attempts faithfully to describe it most miserably fail; it is not the music that is described, but only the impressions it makes upon the recorder, and the stock of our adjectives has long been exhausted by one clever writer after another in the vain effort to place on paper this wonderful song. Perhaps we are most correct in saying that the song of the Nightingale is not excelled by that of any other known bird. It is impossible alike to describe the varied notes as to give the order of their sequence. The song is varied to an exceptional degree, the sweeter notes being marvellously beautiful, but these are often punctuated by others which are harsh if not absolutely unmusical. The wonderful way in which the song pours forth in a perfect torrent as if expressing the fiercest rivalry, or changes to lower or softer toncs as if of endearment, or yet again to notes indicative of triumph, of taunt, or threat, or passion, is known to every one at all familiar with its voice. The song is also characterized by much repetition, but we do not think the bird is much of an imitator of the songs or cries of other species. Much that is attributed by some writers to imitation or mimicry is merely due to coincidence, or even fancied resemblance on the part of the listener. Upon its arrival the Nightingale will be noticed to sing much during the day, but as the spring draws on it becomes more of a night vocalist, and we have remarked that the 
song is exceptionally fine in the twilight, both just before sunrise and after sunset, especially during warm settled weather. The bird continues in fine voice throughout May, but in June a falling-off is perceptible, and finally the song is hushed during the latter part of the breeding season. This species is in great request as a cage-bird, but it is one that takes poorly to captivity.

Whether the Nightingale pairs for life we are not prepared to say, but individual birds are certainly in the habit of returning to certain haunts each season to breed, and these are very jealously guarded from intrusion. The Nightingale nests in May. In our islands the nest is usually placed amongst the rank herbage in the bird's haunts, often in a bank, in a hedge-bottom, or in a drift of last season's dead leaves. Sometimes it is made amongst ivy a foot or more from the ground, but more generally it is upon the ground. This nest is something similar to that of a Robin, of large size, and chiefly composed of dry grass, bits of rush, leaf, and quantities of dead leaves, usually those of the oak, and lined with roots, finer grass and a little horsehair. The five or six eggs vary from dark olivebrown to bluish-green, sometimes with a darker cap at the end, and streaked with one or two hair like lines or scratches. The female bird performs the chief duty of incubation; and both parents are very undemonstrative at the nest. 
The food of the Nightingale is chiefly composed of small worms, grubs, insects, and in fruit-time currants, raspberries, and wild strawberries. The young appear to be reared on the larvæ of moths and butterflies, and on ants and their eggs. The southward migration of the Nightingale takes place in September.

The Nightingale has the general colour of the upper plumage russet-brown, shading into dull chestnut on the tail; the wings are dark brown. The under parts are buffish-white, suffused with brown on the breast and flanks. The female resembles the male in colour, and the total length is about six and a half inches. 


\section{THE ROBIN}

\section{ERITHACUS RUBECULA}

OF all our favourite song birds the Robin is most familiar and best beloved. We have finer singers, it is true, yet none so prime a favourite as the Robin. These sweeter vocalists pay us but fleeting visits and desert us with the change of season; not so the Robin, for as the winter draws nigh he approaches us still more trustfully, and warbles to us notes of prophetic cheerfulness. Wherever there is sufficient cover this species may be found resident throughout the British Islands from the Orkneys to Land's End. Like many other birds that might be mentioned, the Robin has extended its range northwards with the planting of trees and the bringing of waste lands into cultivation. Its extra British range embraces the whole of Europe up to or even beyond the Arctic Circle. In Russia, however, it is said to become rarer, and no cases have been recorded of its breeding east of the Urals. South of the Mediterranean its range extends to 


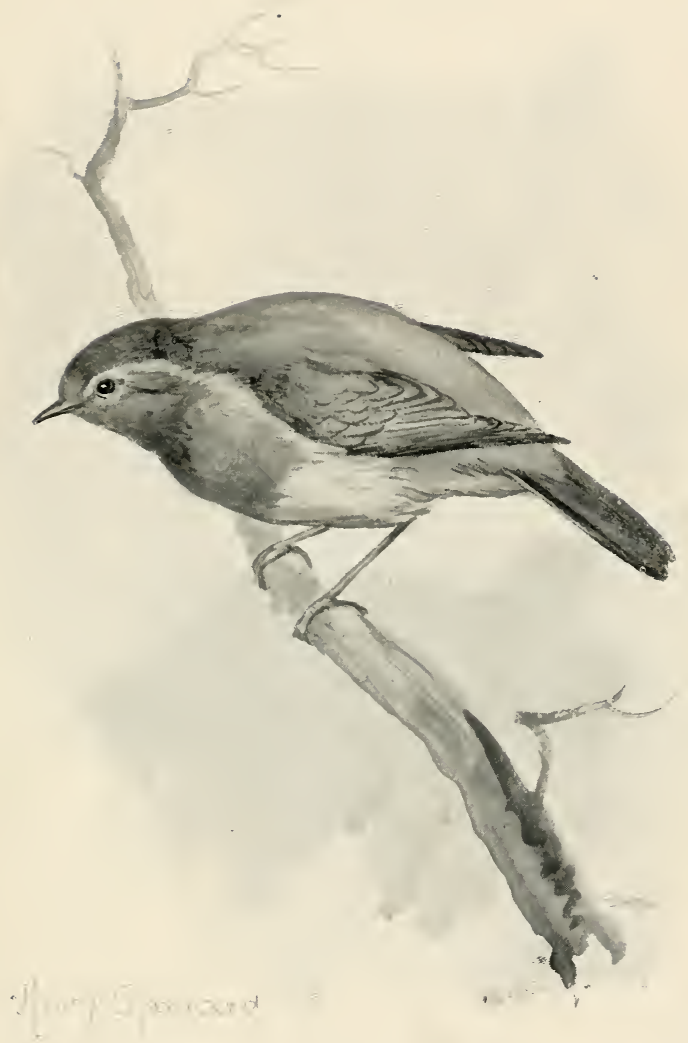

RobIN 



the western parts of North Africa, and the bird is said to be a winter visitor to Turkestan, Persia, Palestine and Egypt. Its southern range in Africa is at present undetermined, but it includes the Canaries, Madeira, and some of the Azores.

The Robin is a resident in the British Islands, but there can be no doubt that its numbers are increased in some localities by migrants from the Continent. It is a very common bird on passage at Heligoland, both in spring and in autumn. The haunts of the Robin are changed somewhat according to season. In summer the bird shows more tendency to frequent woods, shrubberies, fields, hedgerows and lanes; in winter it draws nearer to houses, and then may be observed more commonly in gardens, about sheds and farmyards. We hasten to qualify these remarks by saying that many birds live all the year round close to our habitations; the number of these house Robins increases in winter. With the return of spring a marked clecrease of numbers is perceptible, for then the birds have retired to their more remote nesting-places in woods, hedgerows and the like. Robins that live in the immediate vicinity of houses are most engagingly trustful in their habits, exhibiting a fearlessness which wins all hearts. As if by some subtle reasoning sense the Robin seems to know that he is safe from harm; the expression in his large dark eye is one of trustfulness and 
confidence. The dainty way in which he suddenly alights almost within arm's-length, with a nod and a flick of his wings and tail by way of greeting, must be familiar to every reader. There is something very Thrush-like in the actions of the Robin. We note the same sudden and silent method of hopping towards some tempting morsel, the moment's pause, the quick seizure and swallowing, followed by another pause; the same nervous flicking of the wings; the same abrupt departure into the adjoining bushes, the same look of inquiry from the round, full eye. The Robin is a pugnacious bird, and quickly resents any intrusion into a favourite retreat. It is seldom indeed that two Robins can tolerate each other's presence in the same spot for a moment ; the weaker usually retires, as if with an apology for the intrusion; but very often a combat decides the right of place. This pugnacity is by no means lirected exclusively against other Robins, but xtends to Sparrows and many other birds. The resent species is a bird of the underwood, rarely being seen far above the ground, unless when engaged in song. It is an active little bird enough, hy no means a skulking one, and yet one that likes to be for ever in and out of its cover; now hopping into the open path or on to a post or wall, then back into the bushes or the wood-heap. It rarely flies for any great distance at a time, save when migrating, and its flight seems by no means powerful, 


and usually taken at a very moderate height. The usual call-note of the Robin is both clear and sharp, and generally uttered several times in quick succession accompanied by a bobbing motion. The weeping note, almost peculiar to the nesting season, is particularly plaintive, and in some districts is said by the country folk to be an ill omen. A "weeping" Robin in Devonshire is said to foretell death.

The singularly sweet and plaintive song of the Robin is practically unique so far as British birds are concerned. There is no other song with which it can be compared; it has a distinct character peculiarly its own. Of all our native bird music it is perhaps the saddest; and yet withal it is a cheerful song, a melody of hope poured forth amidst the ruined woods and dripping trees touched with the decay of autumn, or from out the snow-decked branches when gaunt winter reigns supreme. In its way the Robin's melody is national music; and in almost every part of the world to which England has sent her sons as colonists, some bird more or less like a Robin in appearance, has been chosen as the deputy of the red-breasted bird which the emigrant ever associates with "Home." The song of the Robin is not a very lengthened one, but is warbled time after time with pleasing persistency. Then again, with the exception of the moulting season in July and August, it is a perennial song, one that is heard summer and winter alike, and comes out in 
greatest prominence when most other songs are hushed. The Robin's trustfulness when singing is exceeded by no other British bird; the bird's pugnacity is also very great; he brooks no rival, and will almost scream defiance, answering every challenge and being answered in return. He also possesses the habit, particularly noticeable in many of the Thrushes, of visiting a certain perch each day to sing. The voice of the Robin is exceptionally sweet and beautiful in autumn and in the very early spring; in summer his music is not so prominent and is apt to be lost in the universal bird chorus so characteristic of that season. The Robin occasionally sings at night, and very frequently in the dusk.

The Robin may be found nesting almost everywhere in country and suburban districts. Possibly the bird pairs for life. It is also double-brooded, and eggs may be found from March to July; in exceptional cases earlier or later. The nest is generally placed in a cosy nook-a hole in a wall, amongst the exposed roots of trees on banks, beneath overhanging banks, and in ivy either on the ground or growing over walls. Curious sites are very frequently selected, such as an old water-can, a meat-tin, a flower-pot, or in a shed or green-house. The nest is bulky, made outwardly of moss, dry grass, great quantities of leaves, and coarse roots, most of the material being in the front, the cup being 
as far back as possible, and neatly lined with fine roots, horse-hair, and very rarely a few feathers. The eggs are from five to eight in number, usually six, and are white in ground-colour, spotted and freckled with brownish-red and grey. Sometimes perfectly white eggs may be found. The Robin sits closely and is often very tame at the nest; if disturbed it usually perches close by and commences to utter a persistent piping cry. It is much attached to a nesting-place, and will continue to occupy certain spots in spite of repeated disturbance.

The food of the Robin consists of worms, insects and their larvæ, and various fruits and berries. The bird is said to be very partial to grapes. In winter, as is well known, it will eat almost any kind of scraps that may be thrown to the starving birds.

The general colour of the Robin is olive-brown, shading into buffish-brown on the flanks, and greyishwhite on the centre of the belly; the forehead, earcoverts, throat and breast are bright orange-chestnut. The female resembles the male in colour; but the young birds in nestling plumage are spotted with buff and black, and have no trace of a "red" breast. The total length of this species is about six inches. 


\title{
THE HEDGE ACCENTOR
}

\author{
ACCENTOR MODULARIS
}

Although the Hedge Accentor, or Hedge Sparrow, as it is otherwise called, is not a very remarkable songster, it is certainly a favourite one, and we cannot bring ourselves to exclude it from the present work. Although future research may yet succeed in showing that the taxonomic position here assigned to this species will have to be changed, there can be no doubt that its affinities (if we accept the test of a spotted nestling) are more with the Thrushes than with the Warblers, and with them we have accordingly provisionally associated it. The Hedge Accentor, with the sole exception of a few of the most barren of the Hebrides, and the Orkneys and Shetlands, may be said to be generally distributed throughout the British Islands, more or less resident in every county, but becoming least abundant in the wilder and uncultivated districts. It is another of those species which have very perceptibly increased their area of distribution 




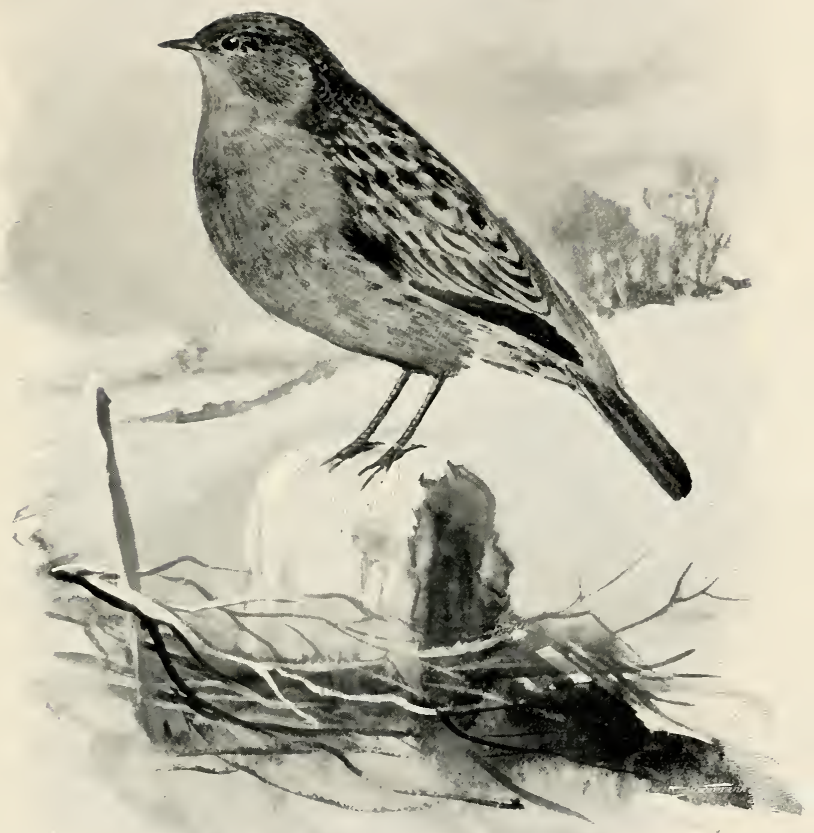

twy

Hedge ACCentoR 

within recent times. South of latitude $70^{\circ}$ in the extreme west, and latitude $60^{\circ}$ in the far east, the Hedge Accentor is commonly dispersed throughout Europe (although said to be very rare in Eastern Prussia), but in the south it is principally a winter migrant and in the north a summer one. A few, however, retire to the mountains to breed in Spain, Italy, Asia Minor, Palestine, and the Caucasian countries. South of the Mediterranean it is only known as an abnormal migrant.

As previously stated, in some parts of its range the Hedge Accentor is a bird of regular passage. It is one of the most familiar birds at Heligoland, so Gätke tells us, and its migrations are a wellknown feature of the ornithological life of the island. Although one of the most solitary of birds, evincing little sociability with its kind, it appears to migrate in companies, even in spring. It would perhaps be more difficult to say where the Hedge Sparrow is not found, than where it is. It is almost as familiar as the Robin, and equally as ubiquitous, and in its choice of a haunt manifests a decided partiality for cultivated districts and the dwellings of man. Dressed in sober-coloured plumage, un assuming and somewhat retiring in disposition, it attracts little attention, and is as often as not overlooked altogether. It is essentially a ground bird and one that frequents the lower vegetation, rarely visiting the higher branches, except occasionally to 
sing. In its method of gliding rapidly through the dense cover it puts us in mind of the Warblers; whilst its habit of suddenly hopping from the hedge to the ground at once suggests the Robin. It is a bird that flies little, and seldom for long distances, always preferring to elude pursuit by keeping to the bushes, and is at all times a restless bird, strongly addicted to the habit of nervously flicking the tail and wings. We have said that the bird is eminently a solitary one, rarely seen even in the company of its mate, save during the breeding season; and yet there are times when the Hedge Sparrow seems to become unaccountably social. This is during the pairing season, and at that time the little creature develops a most pugnacious habit, and fights frequently with rival birds. The call-note of this species is a particularly plaintive one, a peevish and complaining cry that seems to express discontentment with things in general. The familiarity of this species is only exceeded by that of the Robin. It will often attend us in our outdoor avocations, say when gardening, and actually drop down upon the newly-turned earth at our feet to pick up some tempting scrap of food.

As a songster the Hedge Accentor does not claim very high rank, but there are one or two features in its music which are certainly of a redeeming character. In the first place, in all fairly sheltered localities, it is a perennial song, not quite 


such a freely uttered one as that of the Robin, but one that is generally evoked by a sunny interval in the winter's dreariness. In the second place it is decidedly a cheerful song, yet just a trifle plaintive, somewhat resembling the first part of the Wren's song, beginning full of promise, but unfortunately stayed before better things are reached. To our mind it always gives the impression of a performance which has been suddenly checked and disturbed in the middle. The Hedge Accentor is certainly a persistent singer, especially in early spring, warbling forth one little refrain after another with delightful perseverance. It is a bird that is frequently heard well into the dusk, and is one of the earliest of our songsters to recommence at dawn.

Another thing which endears the Hedge Accentor to most of us is its charming little nest, often built in situations that betoken trustfulness of the rashest kind. It is also one of our earliest birds to make an effort in this direction, and many a pretty nest comes to grief through a late fall of snow or a prolonged frost. The favourite nesting-places of this species are hedges, shrubberies, gardens, and low underwood. 'The bird appears to pair very early, even in January, and often months before a nest is made. Although several nests may frequently be found in the same hedge we do not notice any social tendency. The nest is never built 
very far above the ground, and is usually placed in a whitethorn hedge, amongst briars and brambles, in low bushes or heaps of hedge-clippings. Less frequently it may be seen amongst ivy, or in evergreen bushes and gorse-coverts. The nest is made externally of moss, dry grass, dead leaves and a few slender twigs; internally of hair, wool, and feathers. The cup is deep and exquisitely rounded. The eggs are from four to six in number and are of a beautiful turquoise-blue, without spots of any kind. Both parents incubate them, the sitting bird remaining on the nest until the last moment, and then fluttering away into the cover without further demonstration. This species is much attached to its nestingplace, and for years will build its mossy home in one locality. Many nests come to grief, through being made in exposed situations; indeed the nest of the "Dunnock" is the school-boy's first and most frequent prize in the earlier months of the year. Several broods are reared during the course of the spring and summer, the nesting season of this species extending from February to July. The Hedge Accentor, in our islands, is one of the Cuckoo's most favourite foster-parents.

The food of this species consists of small worms, insects and larvæ, and small sceds of various kinds. In winter the bird frequently comes near to houses to pick up any scattered crumbs, and is often seen near piggeries or in fowl-runs and farm-yards. 
The Hedge Accentor has the general colour of most of the upper parts brown, the feathers having dark brown centres which give the bird a streaky appearance; the head, nape, and ear-coverts are grey; the wings and tail are dark brown, most of the feathers of the former with margins and tips of reddish-brown, and those of the latter with pale brown. The throat is grey, shading into a paler tint on the breast and centre of the belly, and into pale brown on the flanks, which are streaked with darker brown. The female resembles the male in colour, but the young in nestling plumage are mottled and spotted with dark brown and buff, and the slate-grey is wanting. The total length of this bird is about five and a half inches. 


\title{
THE SONG THRUSH
}

\author{
TURDUS MUSICUS
}

We now reach the typical Thrushes, and of them the Song Thrush has an unquestioned right to piemier place. Of all our larger birds of song it is not only the most familiar, but unquestionably the must popular favourite. $\mathrm{He}$ is the one vernal chorister that appeals most widely to the multitude. The Song Thrush is one of the most generally distributed of British birds, and may be found, at least as a summer resident, in all parts of the country, with the trifling exception of some of the wilder Hebrides and the Shetlands. Outside our area the range of this species is a somewhat wide one, embracing the whole of Europe and Asia, as far east certainly as the valley of the Yenesay, and as far north in the extreme west as the Arctic Circle, but not higher than latitude $60^{\circ}$ in the extreme east. In South Europe, North Africa, and South Persia it either ascends mountains to breed, or is a winter migrant only. Its southern limits in Africa appear 


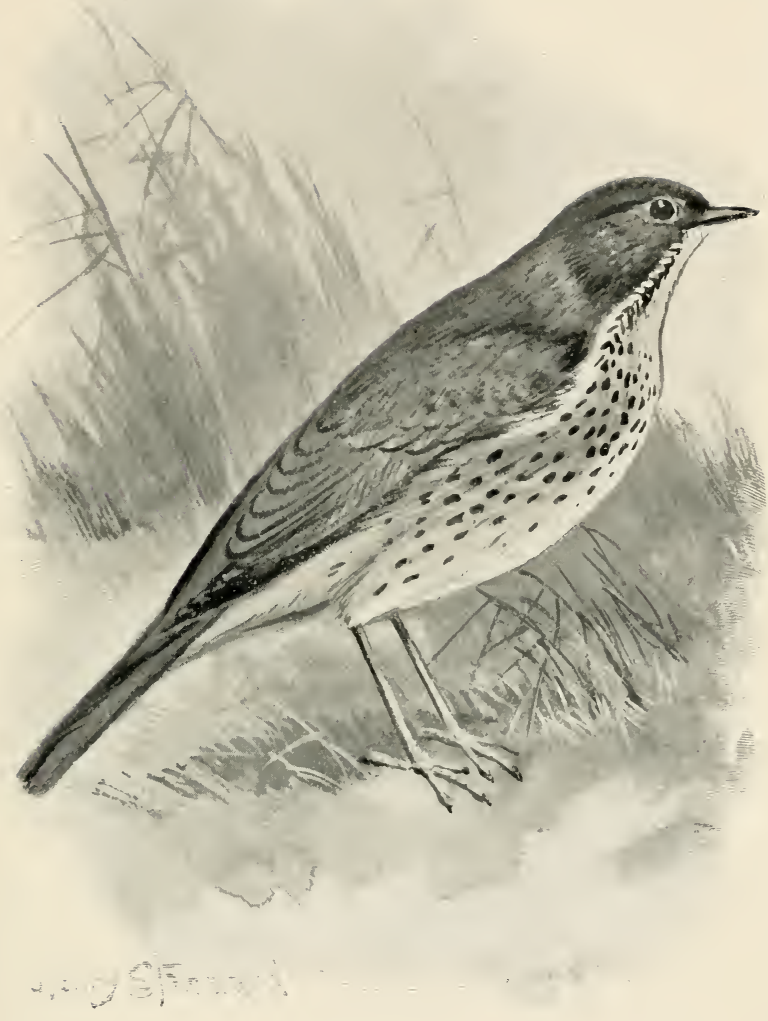

SoNg ThkUsh 

not to be very accurately determined, but are said to extend as far as Nubia, perhaps in exceptional cases only.

In the British Islands the Song Thrush is but a partial migrant; that is to say, in some of the least cultivated districts especially, the birds leave during most of the winter. In many continental areas, however, this Thrush is a regular migrant; and in Heligoland vast numbers of birds, particularly in autumn, cross the island, where they are caught for food in large quantities. The migrations of this species in our island are not very clearly defined, and still require much investigation. The Song Thrush is almost as ubiquitous as the Robin and the Hedge Accentor. It is not quite so familiar, but it may be seen in almost every kind of locality at all suited to its requirement, even in parks and pleasure-grounds in the centre of busy cities. It is certainly most partial to the well-cultivated districts, orchards, shrubberies, gardens, hedges, the smaller woods, coverts, fields, and plantations. Nowhere perhaps is it more abundant than in shrubberies adjoining country houses. It is a ground bird for the most part, finding cover amongst the lower vegetation, and chiefly visiting the higher branches for the purposes of song. We cannot exactly describe the Song Thrush as a perfect recluse, still it evinces little partiality for company, and its social tendencies are most marked during the migration season. It 
is somewhat of a skulking bird too, save when engaged in song, fond of hiding away under thickets and the ground-sweeping branches of evergreen shrubs. Much of its food, however, is sought in the open, upon grass land. It is very fond of feeding upon a lawn; hopping out from the sheltering bushes with a somewhat startled and halting manner, looking warily around before trusting itself to search for food, and at the least alarm returning to the friendly cover. It always prefers to hop or run along the ground under brushwood or bushes to taking wing, but when flushed can and does fly rapidly and steadily from place to place. Its harsh grating alarm-note is very frequently heard towards dusk, just prior to the bird settling down to roost; its call-notes are varied, and some of them almost as plaintive as those of the Robin.

What perhaps endears the Song Thrush to the multitude is its splendid song. We may correctly describe him as the first musician of the year; indeed in some localities (in South Devonshire, for one) he might almost claim to be a perennial songster, for there is scarcely a day in winter, provided it is sufficiently warm and genial, on which his voice may not be heard. From November onwards we have many repeated notes recorded of this bird's song; but unfortunately a spell of rough weather will silence him, and in this he is very unlike the Robin. The notes of this bircl, to our 


mind, are fuller of the promise of spring than those of any other. $\mathrm{He}$ is indeed the most persistent singer of the spring, always, early and late, overflowing with music. An attempt to describe the music of this matchless songster is almost as vain as it is unnecessary. If "variety is charming," then the voice of the Song Thrush must be charming indeed. Its charm consists not only in the clear rich notes themselves, but in the perfectly marvellous way in which these notes are varicd, perhaps never given forth twice in exactly the same order. Each variation is repeated, often given again and again, and the bird seems literally to amuse itself in forming a variety of combinations. $\mathrm{He}$ is a most persistent singer too, and will sit and carol for an amazing length of time from one particular perch, often high up in the trees where his spotted breast is lost in the distance. No wonder that this bird is a favourite captive; he bears confinement well, and sings freely in a cage, but we prefer his melody in freedom, behind no other bars than those formed by the bloom-decked branches of the trees. The Song Thrush is to some extent a night singer, especially during April and May; we have heard this species singing beautifully at two a.m. in a London suburh. It also sings much during light warm rain, and may even be heard during the progress of a thunderstorm.

The Song Thrush is an early breeder, the first 
eggs in mild seasons frequently being laid by the end of February. The nest is built in a very great variety of situations, but the preference is strongest for evergreen shrubs. Perhaps whitethorn hedges and bushes come next in order of choice; whilst ivy on walls or trees is not an uncommon one. Sometimes less likely sites are selected, as for instance in a shed, or on a wall, or a bank. It may either be built absolutely on the ground, or from a few feet to twenty feet or more above it. The nest is somewhat bulky, and made outwardly of dry grass, bits of moss, dead leaves and a few fine twigs. This is first lined with a coating of wet mud, and finally finished off with another lining of wet rotten wood. Very often the nest is left to dry for a day or so before the first egg is laid, but not unfrequently this is deposited in a wet nest. The eggs are four or five in number, exceptionally six, and are turquoise-blue in ground-colour, more or less thickly spotted with blackish-brown and grey. The spots are rarely very large or numerous enough to conceal much of the ground-colour. The bird is a close sitter, and when driven from the nest often becomes very noisy. Several broods are reared in the season, which lasts from February to August. Young birds are very easily reared in confinement.

The food of the Song Thrush consists largely of worms, grubs, and snails. The bird is far more 
of a snail feeder than any other British Thrush, and is very adept at breaking the shells, by striking them on a stone, to obtain the animal lurking within them. It is not so much of a berry feeder as the Fieldfare or Mistle-Thrush, but is somewhat partial to fruit.

The general colour of the upper plumage of the Song Thrush is olive-brown; the wings and tail are darker brown, the coverts of the former being tipped with buff. The under parts are white, shading into fulvous-brown on the breast and flanks, and for the most part boldly spotted with brownish-black. The femalc resembles the male in colour; but the young in nestling plumage are spotted with buff on the upper parts. The length of this species is about nine inches. 


\section{THE MISTLE-THRUSH}

\section{TURDUS VISCIVORUS}

Generic affinity must be our sole reason for placing the Mistle-Thrush next in order of our favourite songsters, and not musical ability. This Thrush is another widely-distributed species in the British Islands, perhaps most abundant in the northern half of England. It certainly breeds as far north as the Orkneys, as well as on many of the Hebrides, and although said to be unknown in Ireland a century ago is now widely dispersed there. This Thrush is another species which has extended its area within recent time, following the planting of trees in any direction which may be compatible with the laws of avine dispersal. Its extra British distribution is a wide one, comprising most parts of temperate Europe, and in the extreme west ranging as high as the Arctic Circle. In Asia, subject to slight modifications of size and colour, the bird ranges at least as far as Lake Baikal and the North-west Himalayas. To the south of Europe 


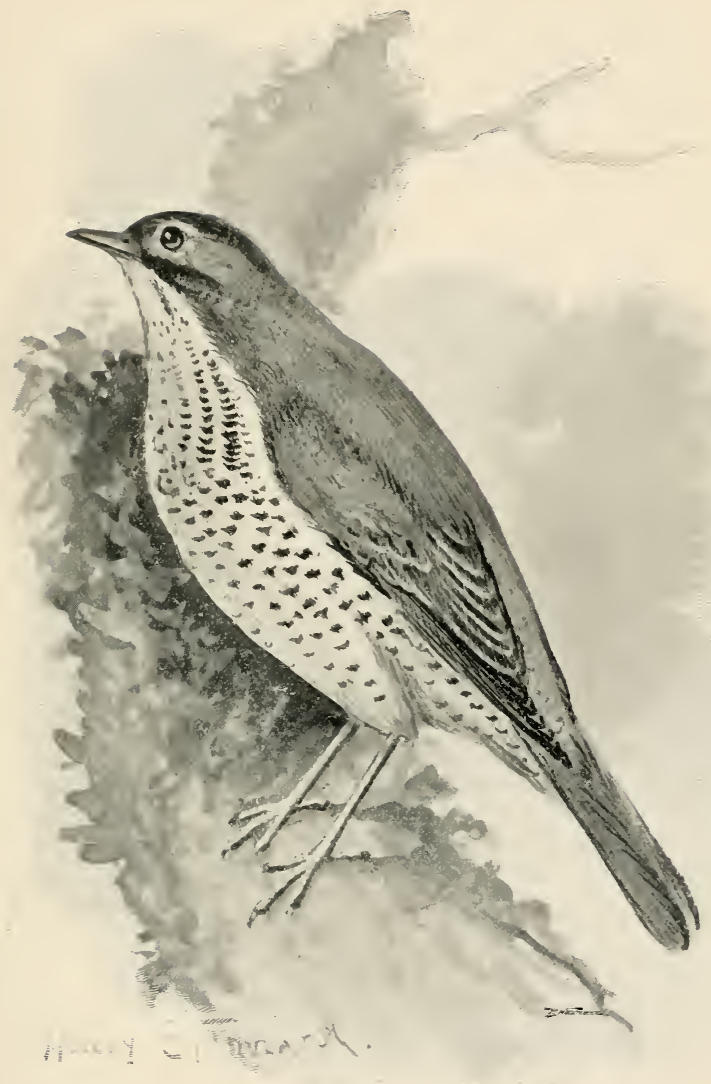

MISSEL Thrush 



and North Africa the bird is best known as a winter migrant, as it also is in South Persia, but some individuals appear to ascend the mountains to breed on the northern shores of the Mediterranean. To a great extent the distribution of this species is controlled by the presence of wooded country.

The Mistle-Thrush is not only our largest but our wariest songster. It is a resident in the British Islands, but subject to a certain amount of local migration, especially in the northern and more exposed localities. Flocks of this Thrush also visit our islands in autumn from continental districts. Next to the Ring Ouzel, the Mistle-Thrush is the least familiar of our native Thrushes, showing a marked preference, especially in summer, for wild uplands and the more remote areas. It is also the most gregarious, in this respect resembling the non-indigenous Redwing and Fieldfare. The haunts of this Thrush are chiefly confined to wooded districts, in which, during the non-breeding season, it is generally wandering about. For the greater part of the season it is a somewhat solitary bird, but in autumn there is a strongly-marked tendency to gregariousness displayed. Save when feeding this handsome Thrush is not seen much upon the ground; neither does it frequent underwood or evergreens. When flushed it usually hurries off at a considerable height or takes refuge in the taller trees. These remarks more particularly relate to 
the non-breeding season; but whilst engaged in duties of reproduction it not only frequents lower situations but its habits are considerably changed in other ways. Its actions on the ground when feeding are very similar to those of other Thrushes. It hops restlessly about in quest of food, has the same halting startled sort of way with it, is easily alarmed, and when flushed flies rapidly and generally for some distance ere alighting again. After the breeding season, in the late summer and early autumn, it collects into flocks of varying size, but these usually disband again long before the winter is over.

The Mistle-Thrush is a sweet and powerful singer, but one very remarkable fact concerning his song is the time of year it is chiefly indulged in. Unlike all the other British Thrushes the present species becomes practically mute when other birds are overflowing with music. His song is confined to the late autumn and winter months, beginning in September and ceasing in March. This peculiar habit has led to the bird being called "Storm-cock" in many country places. We may safely attribute this peculiarity in the Mistle-Thrush to the birds pairing during this period. The song, though somewhat short and lacking much variation, is singularly loud, wild, and beautiful, the component notes being both clear and sweet. It is rather monotonously uttered time after time; but the bird is most per- 
sistent in his song, and we have known him remain upon one branch in a lofty elm tree for three hours in succession, singing at regular intervals the whole time. He sings well into the twilight, and often commences before dawn; whilst the rough weather peculiar to his singing season must be exceptionally inclement to stay his gladsome voice. We have repeatedly heard this gladsome singer carol sweetly while blinding sleet has been falling, and at other times listened to his well-known lay as it could only be heard in fitful snatches during the brief lulls of a howling gale. A songster such as this surely claims our warmest admiration. If alarmed whilst singing he usually flies off to another tree and at once begins anew.

As the breeding season approaches, the habits of the Mistle-Thrush undergo a very marked and curious change. From being one of the shyest and wariest of birds it becomes one of the most trustful. All its wonted reserve seems gone, and it fearlessly approaches our habitations and makes its nest in the most exposed situations. But as some kind of safeguard against such temerity it also becomes more skulking in its habits, more unobtrusive and much more silent. Indeed a pair of these Thrushes will often rear a brood in an orchard, and the fact never become known until the noisy young are abroad, and all inducement to secrecy is over. The favourite breeding-places of this Thrush are 
woods, plantations, coppices, orchards, parks, and farm lands. In less cultivated districts it frequents the alders and birches on the banks of mountain streams, or the birch and fir woods. We have occasionally known it to breed amongst the evergreens of shrubberies. The nest is generally placed at some considerable height from the ground, in a fork, or on a branch close to the stem, less frequently amongst slender twigs. It is a very handsome structure made of twigs, coarse grass, tufts of chickweed, and often large masses of wool, lined first with mud and then with a very thick layer of fine grass, much of it often green. Some nests are almost exclusively made externally of green bog moss with a few twigs round the margin; but in all cases the lining of fine grass is inserted. Although so frequently made in a very exposed situation, and perhaps with a long streaming tuft of wool dangling from the side, it most unaccountably escapes detection. The eggs are four in number, never more, and rarely less. They are bluish-green or reddishbrown in ground-colour, spotted, blotched, and freckled with dark purplish-brown and pale grey. The parent birds are remarkably quiet during the nesting period unless alarmed. Then their noisy cries and angry demonstrations are very marked, and they will fearlessly dash round an intruder's head or fly to and fro with little show of fear. This Thrush is double-brooded. 


The food of the Mistle-Thrush is largely composed of worms and grubs during summer, and of various soft fruits and berries during winter. The bird will also eat seed grain. This Thrush is popularly associated with the mistletoe, on the berries of which it is thought chiefly to feed. The bird may be responsible for decimating many of the seeds of this parasite, but it does not feed upon them to anything like the extent that is so generally believed. The alarmnote of this Thrush is very harsh and grating.

The Mistle-Thrush has the general colour of the upper parts olive-brown, suffused with rufous on the back; the wings and tail are brown; the under parts are white, boldly marked with large fan-shaped dark brown spots; the axillaries are white. The female resembles the male in colour, and the nestling is profusely spotted on the upper parts and wingcoverts. The length of this Thrush is between ten and eleven inches. 


\section{THE BLACKBIRD}

\section{MERULA VULGaRIS}

Wiтн the Blackbird we reach the Ouzel division of the Thrushes, comprising upwards of fifty species. Our own Blackbird is one of the best known of British songsters and is widely distributed throughout the country, breeding even in such wild and remote areas as the Hebrides and the Orkneys. Like some other birds we have already treated of, the Blackbird has increased its area considerably during recent years, following the planting of trees and the spread of cultivation. The extra British range of this Ouzel is comparatively restricted, reaching in West Europe up to, or slightly beyond, the Arctic Circle, but in Russia apparently not beyond the valley of the Volga. Further eastwards the range extends to Asia Minor, Palestine and Persia, but beyond these countries, in Turkestan, Afghanistan, and Cashmere, our bird is replaced by a larger form. The range of the common Blackbird extends southwards across the Mediterranean into 


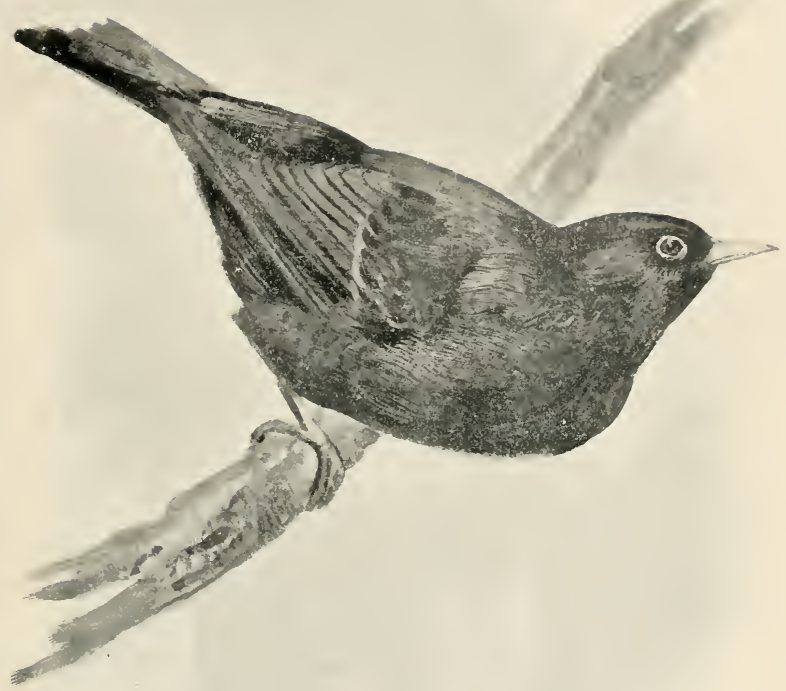

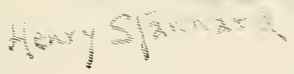

BLACKBIRD 

North Africa, and includes the Canaries, the Azores, and Madeira.

In its choice of a haunt the Blackbird shows a decided preference for shrubberies, hedges and thickets, especially "sunk fences"; gardens and orchards are also favourite retreats. It also has a great liking for marshy or swampy places. In our islands the Blackbird is a resident, subject to a certain amount of local movement; whilst in autumn its numbers appear to be increased by migrants from the Continent. This bird is a wellknown and regular migrant over Heligoland. The Blackbird is by far the least gregarious of the Thrushes in our islands; very rarely a couple may be seen in the same tree, or perhaps several may be flushed from a favourite feeding-place, but they are not drawn together by any social instincts. It is certainly a skulking species, delighting to hide under the spreading evergreens or in the dense hedges and thickets, always trying to elude danger by hopping or running and only using its wings when driven from its shelter, or surprised in the open. The noisy startling cry of this species must be familiar to every reader, uttered as the bird is flushed; whilst its noisy notes of pink-pink, heard especially at dusk, can be scarcely less well known. The Blackbird feeds much in the open, hopping or flying from his retreat amongst the shrubs and thickets on to the grass land, and seldom or never 
failing to elevate his long tail for a moment just after alighting. He is ever shy and wary, resents close observation, and never fails to return to the friendly cover if approached. He searches for food in the same halting suspicious way that characterizes his congeners. This species is somewhat pugnacious, not only to its own kind, but to other birds that may intrude upon its particular haunt. Combats are of frequent occurrence between cock birds during the mating season.

The song of the Blackbird usually begins in February. We do not think this species ever regains its voice after losing it in summer until the return of the following spring: no warm spell in winter will ever coax it into song. Towards the end of February he begins to sing, and continues in fine voice until the end of May; throughout June there is a very perceptible falling off in his music, and in July his voice is finally hushed until another love season calls it forth anew. The notes of the Blackbird are rich and full and flute-like, but unfortunately the song lacks variety and length. It is all too short, the clear musical notes are too splendid to form so brief a song; and not only so, the bird has a most irritating habit of spoiling his own performance by frequently introducing a few harsh notes or letting his song end with them. This usually happens when the singer is disturbed by the a: pearance of a rival. The Blackbird is a 
very persistent singer, and will sit for long periods warbling at intervals without once quitting his perch. He occasionally breaks into song as he flies. He is also a very early songster and repeatedly warbles well into the dusk of evening. The Blackbird's melody is at its best during April.

This Thrush pairs early in the season. Its nest is placed in a great variety of situations, either on the ground, a few feet, or as many as forty feet above it. The favourite situation is the centre of a dense bush, especially an evergreen, and a yew or a holly by preference. Thick hedges, banks, or in the bottom of a hedgerow, or in ivy either on walls or trees are also common sites. The nest is bulky and generally very firmly put together, being composed externally of dry grass, moss and dead leaves, with often a few twigs round the sides; lined in the first place with mud and then with fine dry grass. The eggs are from four to six in number. In exceptional cases we have found as many as eight. They vary from palest blue to bright bluish-green, in groundcolour blotched, spotted and freckled with varying shades of reddish-brown and grey. The amount of colouring varies considerably; on some eggs it almost if not entirely conceals the ground-colour, on others it is broken up into blotches and spots. Both birds assist in the duty of incubation. If disturbed, the parents sometimes fly away with a noisy chatter, but are not nearly so demonstrative as 
the Song Thrush or the Mistle-Thrush. Several broods are reared during the course of the season, which may be said to begin in March and to last until August. Sometimes several nests of this bird may be found within a small area, but the birds are not in any sense gregarious. The Blackbird breeds in greatest abundance in well-cultivated districts, and is specially common during the nesting season near to houses. During the nesting period it often utters a plaintive piping cry.

The food of the Blackbird is largely composed of worms and grubs; the bird also eats snails, but not to such an extent as the Song Thrush. In summer and autumn berries and fruits are devoured, the bird's depredations in the garden often leading to its death at the hands of the short-sighted owner. We have also known this species to feed on newly sown grain and various small seeds.

The male Blackbird has the general colour of the plumage rich black; the bill and the eyelids are orange-coloured. The female is brown, with more or less rufous on the throat and breast, which are indistinctly streaked with darker brown; the bill is black. The young in nestling plumage have pale shaft streaks and dark tips to the feathers of the upper parts, and dark bars on those of the under parts. The total length is about ten inches. 




\section{THE RING OUZEL}

\section{Merula torquata}

The Ring Ouzel is one of those less known species that make their home in the wilder districts. It is a bird of the moorlands and the mountains, dwelling amongst some of the most grandly impressive scenery that our islands contain. It breeds sparingly on the uplands of Cornwall, Devon and Somerset, thence onwards through the mountains of Wales and the north of England to Scotland, including some of the Hebrides, but neither the Orkneys nor the Shetlands. In Ireland it is locally distributed throughout the mountainous districts. Owing to the presence of one if not two very closely allied forms or races it is at present almost impossible to determine the exact area occupied by the Ring Ouzel in continental Europe. It appears, however, to be the typical form that visits the extreme west of Europe from Belgium to Scandinavia, up to about lat. $58^{\circ}$. The bird found apparently as a resident on the mountains of Central and 
Southern Europe was distinguished by Brehm as Merula alpestris; whilst that frequenting the Caucasus has been separated by Seebohm as Merula orientalis. The typical form of the Ring Ouzel retires southwards to winter in the basin of the Mediterranean.

The Ring Ouzcl is a rather early spring migrant to the British Islands, reaching its more southern haunts at the end of March or early in April, the more northern ones a few days later. The birds appear to migrate in companies; certainly they arrive on the northern moorlands in flocks which gradually disperse over the surrounding country to the chosen nesting-places. The haunts of this handsome bird are the rocky moorlands, the craggy banks of the upland streams, the wind-swept summits of the peaks and tors. In its habits the present species very closely resembles the Blackbird. It may not be so skulking; it has neither cause nor opportunity to be so; for its wild haunts are little frequented by creatures liable to work it harm, and bushes and thickets are by no means common in these upland solitudes. Indeed the Ring Ouzel prefers to haunt the rocks rather than the trees, and when not upon the ground in quest of food may usually be seen sitting on the crags. It is wary enough, especially if not engaged in nesting duties, and in this respect almost exactly resembles the Mistle-Thrush. Upon the ground its actions 


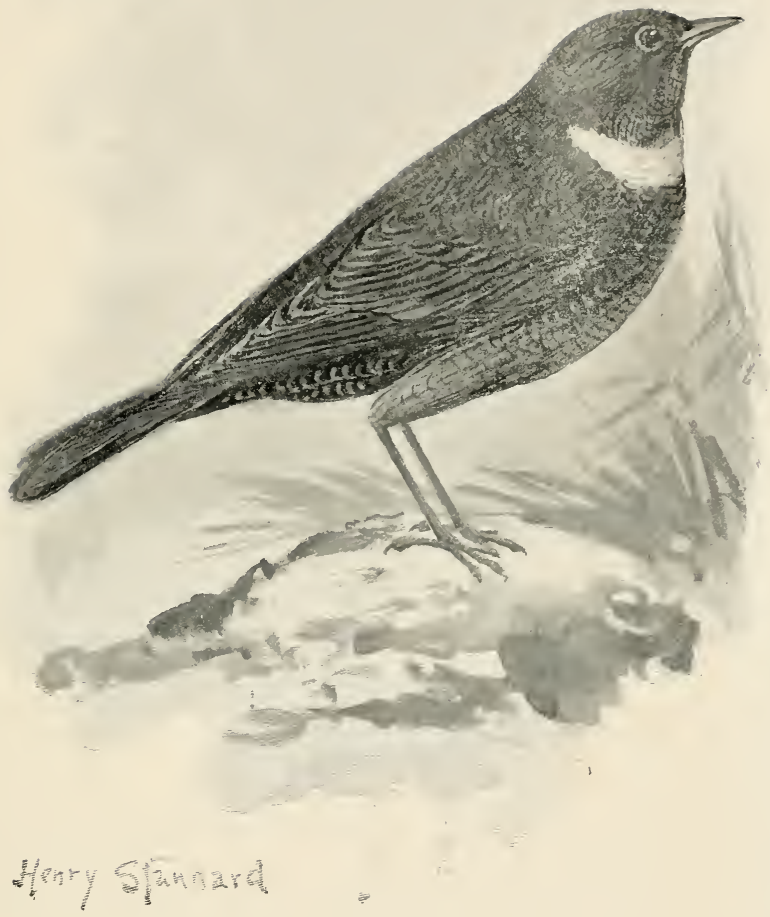

Ring OUSEL 



are very like those of the Blackbird-it progresses in a series of halting stages, digs out its food in the same energetic and alert way, and also possesses the very characteristic habit of raising its tail nearly perpendicular when alighting either on the ground or on a rock or a tree. There is also something very Chat-like in the way this species will retreat before you as you advance into its haunts, perching until you come within a certain distance, then flying on again to await your approach, all the time keeping up a noisy chattering. Sooner or later, however, the bird will make a détour and return to the spot whence it was first disturbed. The Ring Ouzel is one of the easiest identified of birds-a Blackbird with a crescent-shaped white band across the chest, and with the same noisy and persistent cry of tactac-tac heard most frequently if you chance to be near his nest.

Very soon after their arrival on the moors the cock birds may be heard in song. It is whilst singing that the male Ring Ouzel appears to relax his usual wariness, for certainly he permits a nearer approach then than at any other time, except when defending his nest. There is nothing very brilliant about the song of this species; one might almost class it as monotonous; but after all it is very welcome music in such wild country, and the natural surroundings assist in making it attractive. The male bird has the Thrush-like characteristic of 
perching for a long time in one very conspicuous position, and singing at intervals. The notes are loud and full-toned, but unfortunately the Ring Ouzel has the Blackbird's habit, only much more emphasized, of introducing harsh tones amongst them, and literally spoiling his own performance. A few well-piped notes begin the song, but instead of being continued they fall away into what is little more than a rasping chatter; and this is repeated again and again, at intervals perhaps of a minutethe song, as it were, always promising yet never accomplishing, or attaining the beauty suggested by the early notes. The Ring Ouzel sings most persistently through April, but the song declines in Nay and ceases in the early summer.

Although gregarious upon its first arrival the Ring Ouzel is not even sociable during the breeding season. It is interesting to remark that the present species is the only Thrush that migrates to our islands to breed, the Fieldfare and the Redwing being winter visitors exclusively. The breeding haunts of the Ring Ouzel are the rock-strewn hillsides, where birch trees and gorse-coverts are interspersed amongst the big boulders and broken masses of millstone grit, the banks of the mountain streams and pools, where the alders take root literally in the water, or even away on the open wind-swept moor where the breast-high bracken and ling almost conceal the hollows and cart-roads. The nest, which is 
made in April or early May, is either made upon the ground amongst the heath, often at the edge of a sloping bank, or in some low bush or tree. It is very similar in form and materials to that of the Blackbird; indeed no ornithologist is sufficiently expert to distinguish between them. It is made outwardly of dry grass, dead leaves and a few twigs, then lined first with mud and finally with fine dry grass. The eggs are four or five in number, and so closely resemble those of the preceding species in colour and in size that repetition is needless. It is not an easy matter, however, to confuse the nests of these species, for the Ring Ouzel is exceptionally aggressive and bold in defending it from danger, sweeping past the intruder's face with angry cries and fluttering up and down full of anger. The birds will even evince much of this anxiety for an unfinished nest. But one brood is reared in the season.

The food of the Ring Ouzel consists largely of worms, snails, and insects, and larvæ of various kinds. In the later summer months it embraces many sorts of soft berries and fruits which are then abundant in the bird's upland haunts. Gardens are also visited by the Ring Ouzel, often at some considerable distance from its usual haunt, for the sake of the smaller fruits; and during its migration southwards in autumn it frequents the vineyards for the grapes. Shortly before the return migration this 
bird may again be observed in family parties and small flocks. The birds leave their mountain haunts in September, but continue to be seen in more lowland districts during the following month, and rarely into November.

The general colour of the adult male Ring Ouzel is brownish-black, with the exception of the nearly white gorget, reaching from the shoulders across the breast ; most of the small body feathers have whitish margins. The female is browner in colour, and the gorget is not so distinctly defined and is suffused with brown. The nestlings are barred with black and pale brown, and the wing-coverts are streaked and tipped with buffish-white; there is no trace of the white gorget. The total length of this species is about ten inches. 




\section{THE DIPPERS AND IVRENS}





\section{THE DIPPERS AND WRENS}

In a work of the present scope it is fortunately unnecessary to deal with complicated questions of the affinities and taxonomic position of birds, and in associating the above-mentioned species we must not lead readers to suppose that they are by any means so closely allied as this arrangement may seem to suggest. The birds have certain characteristics in common, but this fact may be of no value whatever as an indication of affinities. By earlier writers the Dippers, owing to their aquatic habits, were sometimes associated with the Water Birds; later systematists have grouped them with the Thrushes or the Wrens. Possibly they constitute a very isolated family, with no near-existing relations. About a dozen species of Dippers are known to science, and these are distributed over the mountainous parts of Europe, Asia, and America, and the extreme north of Africa. They are all, so far as is known, sedentary species, and do not present much diversity in the colours of their 
plumage. Perhaps the Dippers do not rank as songsters of exceptional merit, yet their vocal attainments are considerable, and in some species at all events their music is almost perennial.

The Wrens are a much more heterogeneous group, comprising a large number of species, predominating in the New World, yet well represented in various parts of Europe and Asia. They are birds of small size and generally sober plumage. The typical Wrens, of which our British species is a familiar example, are songsters of considerable merit ; but some of the American representatives of the group are still more famous for their musical achievements. One of the most remarkable of these, Cyphorhimus cantans, is thus described by Bates: "When its singular notes strike the ear for the first time the impression cannot be resisted that they are produced by a human voice; some musical boy must be gathering fruits in the thicket, and singing a few notes to cheer himself. The tones become more fluty and plaintive ; they are now those of a flageolet, and, notwithstanding the utter impossibility of the thing, one is for a moment convinced that some one is playing that instrument." Bates goes on to say that this wonderful little singer is the only Warbler in the forest that arrests the attention of the natives, who sometimes, whilst travelling along the shady creeks in their canoes, rest their paddles as if struck by the mysterious song. The song of the Brown 


House Wren (Troglodytes furvus) of Uruguay is described by Mr. Aplin as sweet, "beginning with a few grating notes, and then going off into a run of remarkably sweet, full notes-the latter part reminding one strongly of a good Warbler's song."

Many of the North American Wrens, of which one of the most familiar is the Winter Wren, are celebrated for their cheerful and musical songs. The Wrens are to a large extent migratory birds, especially in the colder regions they inhabit. Even our own well-known British species undertakes migrations in some countries, and is a well-known visitor on passage to Heligoland. The British representatives of the present two groups of birds are few in number. We have but one Dipper indigenous, and two Wrens, one of these being confined to the St. Kilda group of islands. 


\section{THE DIPPER}

\section{Cinclus aquaticus}

The Dipper, Water Ouzel, or "Water Crow" as it is termed beyond the Border, has a very similar distribution in the British Islands to that of the Ring Ouzel, and is confined to the mountainous districts. It is found locally in Cornwall, Devon and Somerset, thence northwards through most parts of Wales and the mountains of the north of England to the Border. In Scotland, as might be expected owing to the greater frequency of suitable haunts, it is more widely dispersed, even reaching the outer Hebrides and the Orkneys. In Ireland, again, it is widely distributed. The sedentary habits of the Dipper are favourable to the preservation of slight local differences, so that throughout the Palaarctic Region there are many subspecific forms and climatic races impossible here to enumerate. The Dipper found in the British Islands, if perfectly identical with continental examples, has a very restricted European ange. It is apparently found in Holland, Belgium, 






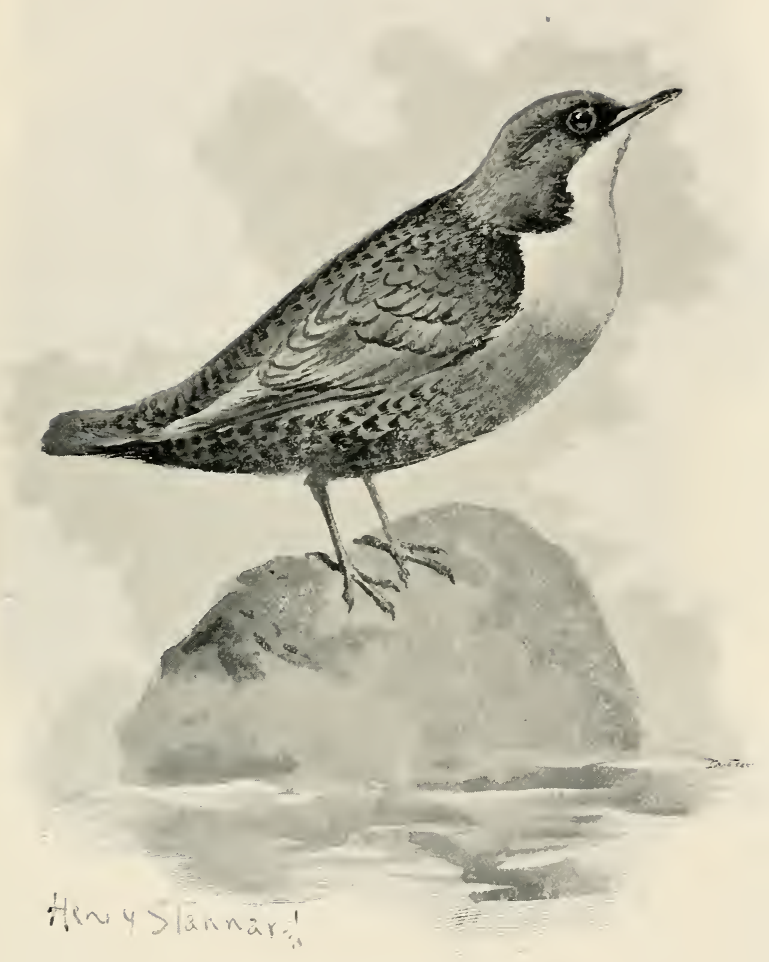

DIPPER 

France and Germany, and perhaps in the Iberian Peninsula; but south of those limits it is replaced by Cinclus albicollis, and north of them by Cinclus melanogaster, the latter occurring in the eastern counties of England as an abnormal migrant.

There can be little doubt that the Dippers found under ordinary circumstances in the British Islands are perfectly sedentary ; they have no cause to wander, and their haunts are tenable the year throughout. The haunts of this remarkable bird are the swiftflowing mountain streams, the rock-strewn, birch and alder-fringed torrents of the uplands and the moors. This species shows little or no partiality for trees, it is for the most part terrestrial or aquatic in its habits, and delights to live on the rocky banks of the stream, flitting from rock to rock before the observer, or flashing past him in rapid flight to a distant retreat, uttering a shrill double chit, it, as it goes. We do not think the Dipper ever seeks to elude an enemy by taking refuge in the water unless wounded ; so that in order to watch its aquatic movements we must stealthily approach its haunts and watch it unawares. The result, to say the least, is a very startling one, for after watching a bird for a few moments standing on the bank or a water-encircled stone, you will as likely as not see it either drop into the stream or run from the bank and disappear below the surface. Here aided by wings and feet it explores the bed of the stream in quest of food, 
probing and poking round the edges of the stones and pebbles, searching amongst the mossy fringes, or in the finer gravel. Then the bird appears again upon the surface, swimming to the shore or fluttering to some big stone rising above the water; where after a short pause it will return to the stream to hunt anew. Sometimes the bird may be noticed to drop into the turbulent stream, perhaps just below a fall, where the water is foaming and wildly agitated, and we are apt to give it up for lost; but if the water be clear the marvellous little diver may be watched darting to and fro in active enjoyment, looking like a mass of silver. Dippers are solitary birds, and except in the breeding season are generally met with alone. In fact each pair seem to have a kind of vested interest in a certain length of the stream, to which they keep, resenting the intrusion of other individuals. Among the characteristics of the Dipper may be mentioned the habit of bowing the head nearly to the ground and elevating the tail; this the bird is constantly doing when not alarmed or fearful of too close a scrutiny. The birds have also a way of chasing each other up and down the course of the stream, twittering noisily.

So far as our experience extends the Dipper does not sing regularly until the beginning of April ; it may be heard occasionally in March; but the winter warblings of this species are exceptional. 
The Dipper cannot be said to rank very high as a songster; still it is a favourite one with all persons whose business or pleasure takes them into its haunts. It is another of those songs whose beauty is increased by associations and surroundings. It is short though pleasing, uttered in a low strain, often lost or only caught at intervals above the noise of the purling stream. We have often noticed the Dipper standing on a rock in midstream warbling cheerily at intervals; whether the bird ever sings from the trees by the stream we are unable to say. The Dipper continues in song through April and May; in June there is a marked falling off, and by the time the young of the second brood are abroad the bird is for the most part mute.

It is most probable that the Dipper pairs for life, for it resorts regularly to certain spots to breed season after season. The nest is seldom, if ever, made at any great distance from the stream, and often placed so close to the water as to be kept moist by the falling spray. It is usually placed in a crevice of the rocks, often under an overhanging shelf or slab of rock, in the masonry of a sluice or weir, under a bridge, amongst the exposed roots of a tree, or more rarely in a niche of the rocks behind a waterfall. It is a large and beautiful structure, similar to that of the Wren, globular, with a hole in the side for entrance. 
Externally it is made almost exclusively of green moss, strengthened here and there, notably round the hole, with grass-stalks; inside this another nest of dry grass, roots, and twigs, and lined with layer upon layer of dead leaves, is formed. Many nests of the Dipper so closely resemble the colour of their surroundings that they are detected with the greatest difficulty. The eggs are from four to six in number, and are pure white, but without the high polish so characteristic of those of the Kingfisher. The sitting bird often allows itself to be taken from the nest without making any effort to escape. This bird is double-brooded.

The food of the Dipper consists chiefly of aquatic insects and their larvæ, worms and small molluscs. These are obtained both from the bed and the banks of the stream. This species has been accused of destroying the ova of trout and grayling, but we feel convinced, from our long experience of the Dipper, that these statements, if true at all, are greatly exagserated. We have dissected Dippers at all times of the year and never found anything of the kind in the stomach; but there can be little doubt that this species catches very small fish occasionally, not habitually, and usually of kinds possessing no commercial importance.

The Dipper is a rather pretty-looking bird owing to the strongly contrasted colours of its plumage. The general colour of the upper parts is slate-grey 


sxcept the head, which is brown, the feathers of the back having pale margins. The chin, throat and upper breast are dazzling white; the remainder of the under parts rich chestnut-brown. The female resembles the male in colour. The nestling plumage is mottled above, the feathers having dark margins; the under parts are white, mottled with grey and brown. The total length of this bird is about seven inches. 


\section{THE COMMON WREN}

\section{Troglodytes parvulus}

FEw burds are better known or more widely distributed than this diminutive species. It may be said to be generally distributed throughout the British Islands, from the Scilly Islands in the south to the Shetlands in the north, although in St. Kilda it is replaced by a closely allied form. South of the Arctic Circle the Common Wren ranges over the greater part of continental Europe and the western portions of Northern Africa, including Madeira and the Canaries. Eastwards it is found in Asia Minor, the north of Palestine, and in the north of Persia, but its limits in this direction are difficult to determine, owing to the presence of various climatic races or closely allied species. Indeed in one form or another the Wren is found over a very great part of Asia and North America, but the consideration of these races or species need not concern us further.

There can be little or no doubt that the Wren, wherever found in our area, is a resident bird. Although nothing nearly so tame and familiar as the Robin, the present species ranks only second to 


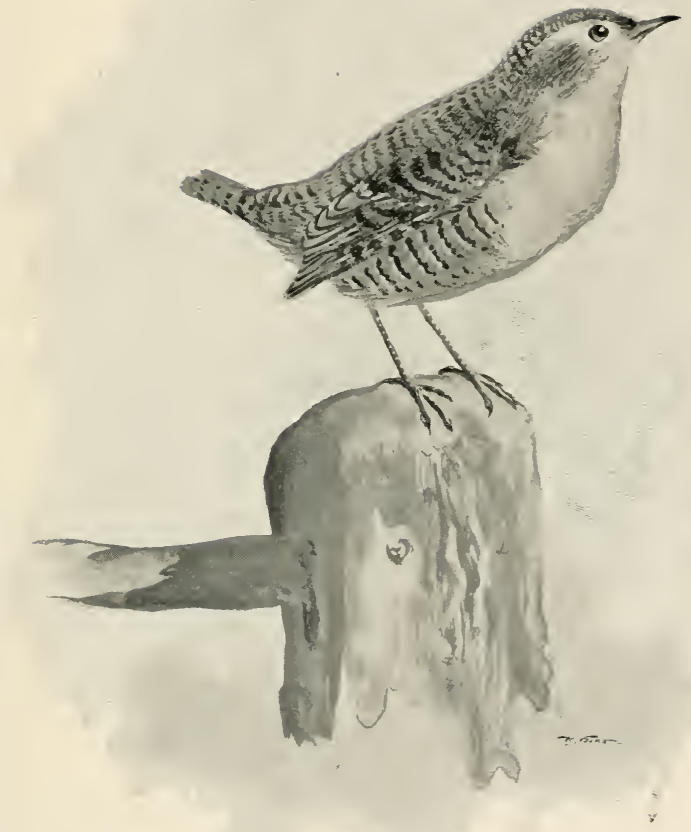

Hew Spantard 

that bird as a popular favourite. It may be met with almost everywhere-woods, hedges, shrubberies, thickets, sunk-fences, dry ditches, gardens, farmyards, remote districts, and in the vicinity of towns and villages; all are equally favoured by the tiny nut-brown bird. Few birds are more restless; it is incessantly on the move, up and down, and in and out, appearing for a moment here and there, then lost to view again, playing an incessant game of hide-and-seek, and in many of its actions more like a mouse than a bird. It is essentially a bird of the undergrowth, rarely seen at any great height from the ground, and through its restless ways only allowing us to gain the most transitory view of its movements. Its actions are by no means Tit-like; rather do they resemble those of the Hedge Accentor; for like that bird the Wren will glide and hop with astonishing speed through the thickest cover. Its flight is weak, and when taken just above the ground the bird looks more like a swirling leaf caught by a sudden gust of wind and whirled along than aught else. For the greater part of the year it is also one of the most solitary of birds, and may be watched going its own way quite alone. It is most amusing to see with what agility this birdmite will twist in and out, squeezing through crevices, and vanishing under roots to appear again in another part of the hedge; or how impudently it will bob its body up and down and cock its tiny tail over its back as it glides once more into the cover. 
If pursued it will readily creep into the first chink it can find, or even bury itself in a drift of dead leaves.

One thing certainly that makes the Wren an object of endearment to most people is its perennial song. With the exception of a few weeks in autumn, during which the bird is undergoing its moult, its loud and cheery song is one of the most characteristic sounds of the country. The most striking part of the song is its loudness, out of all proportion to the size of its producer. The vigorous way in which it is uttered is also very remarkable, the tiny minstrel seeming to exhaust his entire stock of vital energy in its production. At times it seems as though his little throat would actually burst with the tremendous exertion. The Wren's is a song of every season, in harmony with all, never out of place, always cheerful, spirit-raising, and charming. It rings just as clearly and joyously out amidst the snow-draped hedges as in the height of summer; it is equally in keeping with spring-tide balminess and wealth of bloom, as with autumn sadness, falling leaves, dripping woods and general decay. The Wren is no fitful songster either; his glad carol when he is in voice may be heard incessantly all the livelong day, first one bird and then another taking up the stirring chorus. The bird usually remains stationary until the short song is finished, often perched on a bending spray at the top of the hedge; rarely, however, does it remain in exactly the same 


spot to repeat its music, and not infrequently it will commence to sing whilst flying, finishing the song after alighting. This song is a somewhat uneven and jerky one, but contains not a few remarkably clear and sweet notes, and is concluded with a rapid trill, the whole ending abruptly as if the performer had been disturbed in the middle of it.

The Wren is not quite such an early breeder as some of our resident birds, and does not as a rule begin nesting until April. The breeding-grounds are much the same as the general haunts. In some cases at any rate the Wren pairs annually, rather early in the spring, but in others there is strong evidence to suggest that a life-long union is formed. The handsome nest is built in a very great variety of situations-in bushes and thickets, amongst ivy, suspended from a drooping branch, wedged under an overhanging bank in a crevice of the bare soil or rock, concealed among thatch or in the side of a hay-stack, or in wood-stacks or among the exposed roots of trees. Possibly every reader may be able to name an additional site. The materials of the nest vary almost as much, and to a great extent are selected with a view to harmony with the surrounding objects. According then to the special circumstances the nest, which is globular, is made externally of moss, of fern-fronds, dead leaves, dry grass or lichens; the interior is lined with moss, hair and fea hers, the latter varying a good deal in quantity. Round the entrance-hole are neatly interwoven 
grass-stalks, fine twigs or roots. The hen-bird alone makes this wonderful nest, the male, however, conveying much of the material. The eggs are from four to eight in number, usually six, and are white, somewhat sparingly spotted with reddish-brown and grey. The Wren is a close sitter; and when disturbed often becomes very noisy. Several broods are reared in the year.

The food of the Wren is largely composed of insects and their larvæ; but this fare is varied with ants' eggs, small seeds and soft fruits. As is well known, the bird often visits houses in the winter to pick up food scattered for the wants of starved-out songsters. The young birds, we should say, are fed by their parents for some time after leaving the nest. The call-note of the IVren is a loud and shrill tit or tat, rattled off in quick succession, especially if the bird be alarmed.

The Wren has the general colour of the upper parts rufous-brown, barred from below the neck (including both wing and tail) with dark brown; the wing-coverts are spotted with white, forming a double bar, and the quills are also barred with greyish; above the eye is a pale buffish streak. The under parts are greyish-brown, shading into rufous on the flanks, belly and under tail-coverts, which are barred with darker brown. The female resembles the male in colour, but is not quite so brilliant. The nestling closely resembles the parent. The total length of this bird is a little over four inches. 


\section{THE PIPITS}





\section{THE PIPITS}

Associated with the Pipits are the Wagtails, but as none of these birds are songsters of any merit we may discard their consideration here. Wagtails sing but little, and at most their music is but a short and twittering refrain, not sufficiently pronounced to arrest popular attention or to constitute the bird a "favourite songster" in the sense in which that expression is used in the present volume. The Pipits, although very Lark-like in their appearance and habits, are but remotely allied to that group of birds, one of the most important differences being the unscutellated hind part of the tarsus, which in the Larks is covered with a series of plates. This confusion is still popularly maintained by the application of the term "Titlark" to some of the Pipits. About forty species of Pipits are recognized by ornithologists, and these are distributed throughout the world, with the exception of Oceania, or the islands of the Pacific. The Pipits are almost without exception birds of brown or inconspicuous tints, but in South Africa a small 
group of somewhat aberrant Pipits is found remarkable for the bright colouration of their breasts; these are distinguished by systematists under the term Macronyx. Many of the Pipits undertake migrations of considerable extent; others are more sedentary, or move from upland districts to lower country after the breeding season is over. The vocal attainments of the Pipits cannot perhaps rank very high, still some of the species are pleasing songsters; whilst their habit of singing on the wing brings their music into prominence. There can be little doubt that some of the best songsters in this group are those indigenous to the British Islands. Perhaps the most musical extra British Pipits are the Red-throated Pipit and the Tawny Pipit, both species being abnormal migrants to our area. The song of the former is described by Seebohm as being more melodious and prolonged than that of the Meadow Pipit, and more nearly resembling that of the Tree Pipit. We heard much of the Tawny Pipit's song when travelling in North Africa. The bird has the usual habit of fluttering into the air to sing, but not rising to such a height as the familiar Tree Pipit, and its song is almost as loud as that of the Sky-Lark, but neither so rich nor melodious, and of course remarkably short. Three species of Pipits breed in the British Islands-and therefore sing in them-and these we will now procced to discuss. 




\section{THE TREE PIPIT}

\section{Anthus tRIVIALIS}

OF the three indigenous British species of Pipit the present is the sole migratory one, being a wellknown summer visitor to our area. The Tree Pipit is found in most of the wooded districts of England, with the exception of Cornwall and parts of Devon, where it becomes very scarce and local, as it also is in Wales. In Scotland it is also a local and by no means common species chiefly confined to the southern districts, although known to breed at least as far north as Sutherlandshire. In Ireland it is either excessively rare, or overlooked, and the evidence of its having bred in the sister isle is incomplete. The Tree Pipit is found in summer in Northern and Central Europe, and in Siberia as far east as the valley of the Yenesay. In Scandinavia it occurs practically up to the limits of forest growth, but in East Russia not beyond lat. $65^{\circ}$, whilst in Siberia it is not known beyond lat. $62^{\circ}$. South of the Balkans and the Pyrenees it appears to be a winter 
visitor only, but a few ascend the mountains in summer to breed. In Greece and Asia Minor it is a passing migrant, but it winters in North-western India, possibly in Persia, and in Palestine and Africa. Its southern limits in Africa are at present undetermined, although the bird has been obtained in lat. $5^{\circ}$ south at an elevation of 8000 feet (on Mount Elgon), where, however, it may probably breed.

The Tree Pipit arrives in its summer haunts in the British Islands in April. It is rather a late migrant, not appearing, even in the south of England, much before the middle of the month, and from one to two weeks later in the north of England and in Scotland. The favourite haunts of this Pipit are farm-lands which are well sprinkled with trees, open spaces in the old forests (such as Sherwood, Epping, and the New Forest), parks, and the borders of woods and plantations. Perhaps an unskilled observer might confuse this bird with the Wood-Lark, but its trim and slim appearance, long tail and Wagtail-like carriage will soon dispel the illusion. We have often remarked how greatly attached this species is to certain haunts, appearing to return to them every summer, even to the identical field or wood, even to use the same perching place on the trees! This we believe to be a habit common to all migratory birds, easily remarked in such species as the Swallow, but apt to be overlooked in less familiar species. The Tree Pipit seldom 


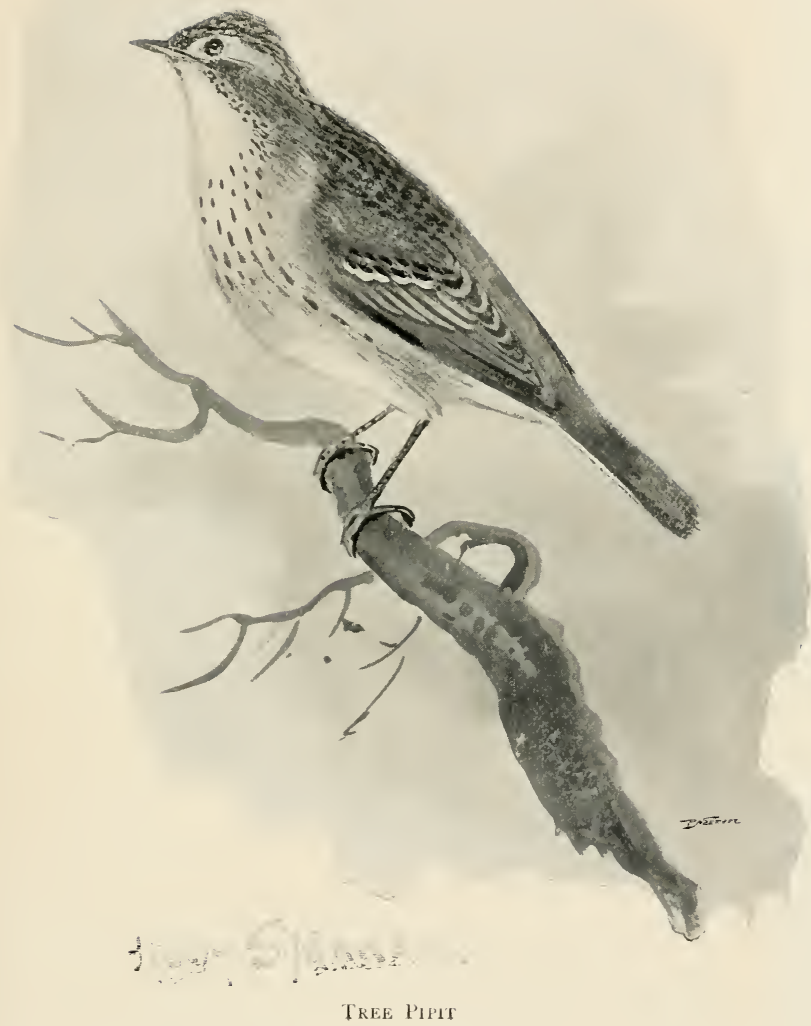



wanders from a particular haunt during the entire summer when once it has settled down to nesting duties. We have often known a pair of birds to frequent one small field for several months in succession. Upon the ground this Pipit is a very active and nimble little creature, running to and fro in Wagtail-like manner. It is not at all social during the entire breeding season, but after the young are hatched the birds wander about in family parties, and as the migration time draws nigh more gregarious instincts are manifested.

The most noteworthy feature about the Tree Pipit is its song and the actions pertaining thereto. Were it not for its song, and the peculiar manner in which it is uttered, this bird would often be overlooked. In fact the Tree Pipit is most readily identified by its habit of soaring into the air from a tree-top, singing as it goes, and after flying for some distance returning to the original starting-place. This song flight is taken nearly perpendicularly at first, then becomes nearly horizontal in its general direction but in a series of curves, the bird floating and hovering and at last returning with tail and wings expanded and almost motionless, back to the starting-place like a shuttlecock. The whole time this flight is in progress the bird has been warbling a melodious song, a rapid succession of clear loud notes, followed, as the song and flight draw to a close, by a prolonged and plaintive double note. Early in the season the Tree 
Pipit frequently rises from one tree and settles in another during the progress of these song flights; but later on when the nest is made, he usually selects some special tree in the vicinity from which he soars. This perch is either on some bare or dead branch, or at the very summit of the tree if amongst the leaves. ()ccasionally the song is uttered as the bird sits on its perch, but then the prolonged concluding double note is omitted, this being apparently peculiar to the descent. The Tree Pipit is a very pertinacious singer, and spends most of the day engaged in these soaring flights and melodious songs. This song may be heard right through the summer, but becomes less frequent after the young are hatched, and is finally lost in the autumnal moult which begins about the middle of July.

Although this Pipit, as its name implies, is a bird of the air and the tree-tops, its nest is invariably placed upon the ground. This nest is generally made in May, and its usual situation is amongst the herbage of the fields, not unfrequently in very exposed situations, where the grass is cropped short by cattle. Hay-meadows and corn-fields are very favourite places, but sometimes a hedge-row bank, or a slope in the woods is selected, and occasionally the herb ge beneath a little bush on the open common. The nest is laced in a slight hollow, and is made of dry grass, moss and roots, and lined with 


finer grass and roots, and horse-hair. It is rather loosely put together, not very large, but neatly finished inside. The eggs are from four to six in number and vary considerably in colour. They vary from greyish-white or bluish-white, to pinkishwhite and pale olive in ground-colour, mottled, spotted and blotched with various shades of reddishbrown, purplish-brown, and olive-brown, and occasionally streaked with irregular blackish lines. On some eggs the markings are very minute and cover the whole surface; on others they form a zone or cap; on others, yet again, they assume the character of irregular and large blotches and round spots. This Pipit is a close sitter, and is very careful in approaching the nest not to betray its whereabouts. As soon as the song of the male ceases for the season this Pipit spends most of its time upon the ground; the trees are seldom visited and the birds live almost exclusively amongst the herbage. It is said that this species rears more than one brood in the season, but this must be extremely exceptional.

The food of the Tree Pipit is principally composed of small worms, insects and their larvæ; but in August the bird may frequently be flushed from the wheat-fields, whither it repairs to feed upon the soft grain. The ordinary call-note of this Pipit is a low and oft-repeated tick. The southward migration of the Tree Pipit begins in September and lasts normally through October. 
The Tree Pipit has the general colour of the upper parts sandy-brown, the feathers with nearly black centres ; the eye-stripe is pale buff; the wings are brown, the greater and median coverts tipped with buffish-white, forming a conspicuous double bar; the tail is dark brown, the outermost pair of feathers white with an oblong brownish patch on the inner webs, the next pair tipped only with white. The general colour of the under parts is pale buff, palest on the breast, spotted or streaked with blackish-brown. The female resembles the male in colour, and the nestlings are similar to the adults but more profusely spotted. The total length of this bird is about six inches. The Tree Pipit may always be identified by its short and curved hind claw, never so long as the hind toe. 




\section{THE MEADOW PIPIT}

\section{ANTHUS PRATENSIS}

The Meadow Pipit is one of our commonest birds, and may be found in more or less abundance in every part of the British area, including such outlying islands as St. Kilda, the Orkneys and Shetlands, and the Blaskets. Its extra British range, however, is nothing near so extensive as that of the preceding species. During summer the Meadow Pipit is found generally distributed over most parts of Central and Northern Europe, extending eastwards as far as the valley of the Obi. In the south of Europe it is principally known as a winter migrant, as it also is in North Africa; but in most of this wide area, which includes the Iberian Peninsula, Italy, Greece, Asia Minor, and Palestine, a certain number of individuals appear to ascend the mountains to breed.

The Meadow Pipit may be readily distinguished from the preceding species by its olive colouration, perceptibly smaller size, and long and nearly straight 
hind claw, always exceedin $;$ the hind toe in length. It is a resident in our country, but subject to con siderable local movement, between the uplands and the lower country. In autumn, too, great numbers of Meadow Pipits visit the British Islands, either to remain in them for the winter, or to pass along the coasts to still more southern countries. We do not think any of the indigenous individuals, however, leave Britain at this season. The abundance or otherwise of this Pipit in many localities is entirely dependent upon the season. Thus in many lowland districts the bird is by far the most common during autumn and winter; whilst in many upland ones it is only seen during spring and summer. With this proviso the Meadow Pipit may be found on almost every variety of ground; from the moors and mountains and remote islets, to the commons, fields, highways, and swamps. This Pipit shows a decided preference for wet ground; summer and winter alike it is sure to congregate in swampy localities. It shows no partiality whatever for trees, rarely perching in them, and passing most of its life upon the ground, where it runs up and down in a very lively and engaging way in quest of food. During prolonged frost this bird may frequently be met with near manure-heaps, or on the banks of running streams, even approaching our houses to pick up anything suited to its taste. In autumn it shows a very marked preference for turnip-field., 




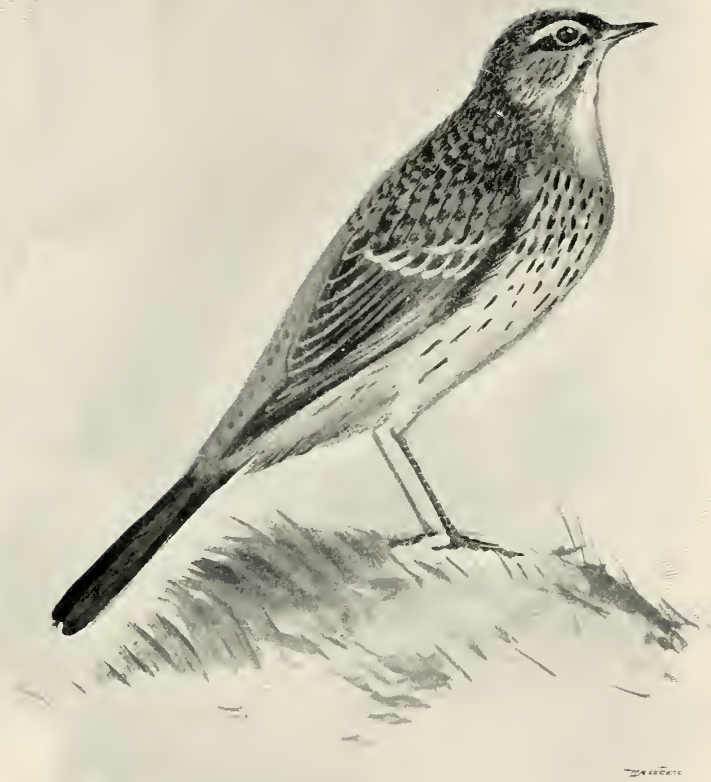

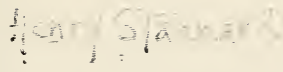

Meanow Pipit 

skulking closely under the broad leaves and uttering a very melancholy and complaining peep as it is flushed. At these seasons it is also to a large extent sociable, and may sometimes be met with in considerable flocks. If disturbed, the entire flock will rise in scattered order, flitting about in an aimless uncertain way, and eventually settling again, two or three birds at a time, here and there, to repeat the same manœuvres if alarmed by the report of a gun. The Meadow Pipit is certainly most gregarious during autumn; in winter the tendency is to gather in small parties; but as the spring days return a further strongly marked sociability is noticed. It is probable that the larger gatherings are connected with migratory movement.

By April most of our resident Meadow Pipits are scattered over their breeding area; the flocks and family parties are disbanded; the birds disappear from many haunts, or become perceptibly less numerous, and reappear in others. It is now that this little species perhaps becomes the most interesting; for the warm spring days have roused its long latent powers of song, and for the next few months it becomes one of our most industrious songsters. We always think this simple song of the Meadow Pipit is most in harmony with the wilder districts, with the haunt of the Red Grouse, Ring Ouzel, and Twite, where the least attractive of bird music is ever welcome, and where it cannot be spoiled by 
contrast with richer and more pretentious melody. This song is uttered (as is usual in the present group) whilst the bird is on the wing, and chiefly during the return flight to the perching place, the upward movement being generally accompanied by a rapid repetition of the call-note, but sometimes made in absolute silence. This Pipit starts its song flights from a perch on a wall, large stone, or low bush, and not from trees. Meadow Pipits are generally much more abundant in a locality than Tree Pipits ever are, and consequently their music often fills the air, the birds rising and falling in short song flights here, there, and everywhere on the waste. The song of this Pipit is neither so loud, so varied, nor so rich in tone as that of the preceding bird; it is also of shorter duration; perhaps we might class it as of about the same merit as that of the Hedge Accentor. This Pipit continues in fair song for about three months.

The Meadow Pipit pairs annually, and early in the year. Its nest may be found in a great variety of places-on the moors, the broads, the cultivated farm-lands, the commons, and even by the wayside, on little frequented country roads. It is always built upon the ground, and almost as invariably well concealed. Sometimes a site is selected among the meadow grass; sometimes under a stone or a bush, or amongst the long moss in a swamp; at other times the long heather, a tuft of rushes, or the 
tangled herbage on a bank. The nest is small and very loosely put together, made of dry grass, moss, dead leaves, or bits of reed, and lined with finer grass, roots and horse-hair. The eggs are from four to six in number, white in ground-colour (although this is generally concealed for the most part by the markings), clouded and spotted and sprinkled with dark brown, and sometimes streaked with blackish-brown here and there on the large end. The bird is a close sitter, usually remaining on the nest until almost trodden upon. The young are fed and tended for some time by their parents after leaving the nest. The Cuckoo makes frequent use of the Meadow Pipit in disposing of its eggs, and the latter birds may often be seen in moorland districts feeding a young Cuckoo with the greatest industry. As a rule this Pipit rears but one brood in the season, but occasionally seems to undertake a second.

The food of the Meadow Pipit is chiefly composed of small worms, insects and larvæ. The bird is specially fond of the smaller aquatic insects and molluscs, and frequently pursues flies in the air. In the colder months small seeds and even grain will be eaten.

The Meadow Pipit has the general colour of the upper parts olive-brown, the feathers with dark centres, except on the rump and upper tail-coverts; the eye-stripe is buffish-white; the wings are brown, 
the coverts margined with white; the tail is dark brown, the white pattern closely resembling that of the Tree Pipit. The general colour of the under parts is white, suffused with buff on the throat and breast, and with olive on the flanks, spotted on the breast and streaked on the flanks with blackishbrown. The female resembles the male in colour; and the nestlings are similar to the adults, but the spotting is more emphasized. The total length of this bird is nearly six inches. 




\section{THE ROCK PIPIT}

\section{ANTHUS OBSCURUS}

The Rock Pipit is found in more or less abundance on all the rocky coasts of the British Islands. Wherever Britain's bulwarks rear their precipitous sides from the encircling sea the Rock Pipit may be found upon them, from the remote Orkneys and Shetlands in the north to the Scilly Islands in the south, from the Farnes in the east to St. Kilda and the Blaskets in the west. The most important length of coast-line from which this species is absent is that lying between the Humber and the Thames. It is as yet an undetermined point whether the Rock Pipit is found outside our limits beyond the Channel Islands and the French coasts. On the rocky shores of the White Sea, and the Baltic, as well as on the coasts of Scandinavia a very closely allied race of Rock Pipit occurs, very similar in winter dress to the British form, but characterized in breeding plumage by the vinous tints of the under parts, which are also devoid of spots. 
The English name of the present bird is but partially descriptive, and to a certain extent even misleading. There is nothing in the term to convey the fact of the bird being exclusively a littoral one, or that its haunts are cliffs rather than rocks. Macgillivray's name of "Shore Pipit" is certainly more applicable, but even this is open to the equally fatal objection that it does not convey the fact that the bird is confined to rock-bound shores only. "Sea l'ipit" might be suggested as a compromise. This little bird is specially interesting, for it is in this country at least the only Passerine species which is confined to the coast. It is never met with out of sight of the sea under any normal circumstances. It is for the most part a sedentary species, although during the migration periods it may be noticed moving along the coasts on passage, and then inhabits less precipitous localities. These migrants, however, appear to belong to the northern race; so far as our observations go (and they extend over many years) the British Rock Pipits are sedentary. No coast is too wild and rock-bound for the Rock Pipit; it may be seen flitting along the face of the beetling cliffs where scarcely a foothold can be obtained, as well as frequenting the boulder-strewed beach, or those localities where the cliffs are more broken into downs. Although an unobtrusive little bird, it is one not easily overlooked, for its complaining note is most persistently uttered, and its short 




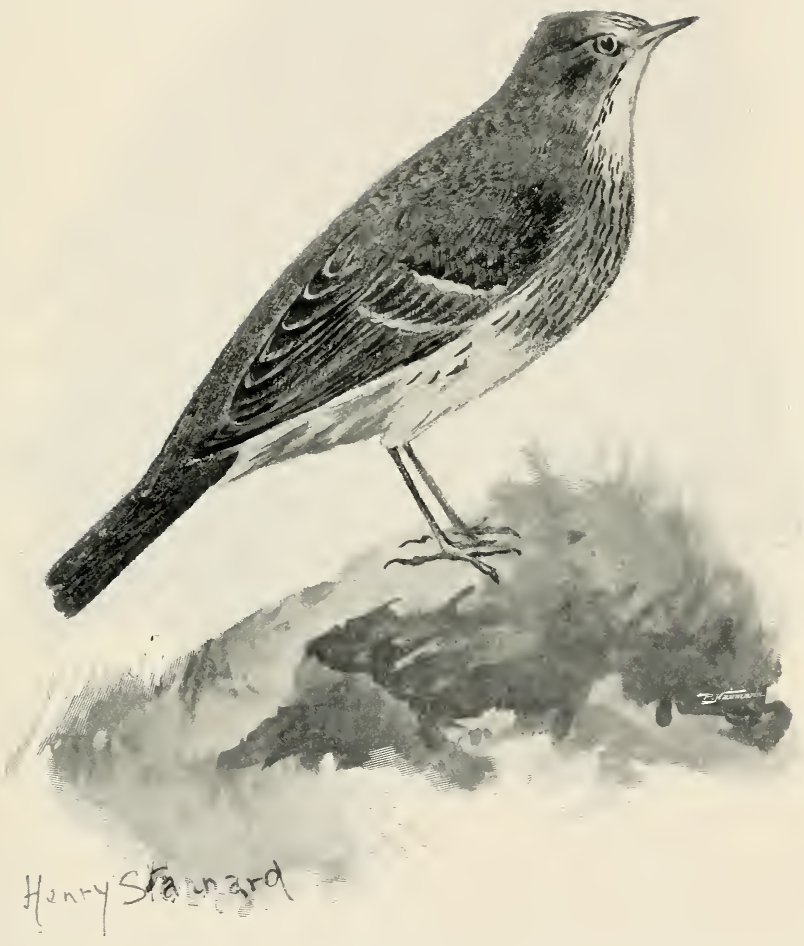

Rock P'IPT 

flights just in advance of our steps seldom fail to draw the attention. It may be identified at once by the absence of the white pattern on the tail (which is replaced by smoke-brown) and by its large size. In general colouration it resembles the Meadow Pipit. Its whole life is almost passed between the cliffs and low water mark. It is by no means a shy bird, and may be watched flitting about the stones and rocks, or running about the shingle and weed-scattered shore, if approached too closely rising in a wavering sort of way, cheeping mournfully as it goes, and agdin alighting a little farther on; and this will be repeated for a long distance if we care to follow. Except in autumn and winter the Rock Pipit is neither gregarious nor sociable; although even in summer many pairs of birds may be met with close together along the same range of cliffs.

Like many other birds we could name the Rock Pipit becomes increasingly interesting in spring. As soon as the first real warm days arrive the bird regains its long-lost song, and from this time onwards until the young ones are hatched, its cheerful strains may be heard along the shore, often almost drowned by the roar of the sea dashing against the bird's rock-bound haunts. Sometimes this Pipit may be heard warbling sotto voce as it sits upon the cliffs, but this is exceptional, for the Rock Pipit like its congreners sings chiefly as he flies. He has 
the same habit of flying up into the air to warble his short rambling song; and up and down he goes at intervals all the livelong day. The song is delivered in much the same way as that of the Meadow Pipit, the bird starting upwards rapidly repeating its call-note until the zenith of the flight is reached, when its music commences and is continued until the ground is reached again. The song is sweet and musical, but far too short; still it does not compare unfavourably with that of the preceding species; indeed of the two birds its music may be the best; but in these cases associations go a long way in our determination.

The nesting season of the Rock Pipit begins in April, and as the bird appears to be double-brooded, it is continued to July. The nest of this species is so very carefully hidden that its discovery is seldom an easy task, and more often than not the resuit of accident rather than careful search. It is generally placed in some sheltered nook, as for instance under a flat stone, or a mass of loose rock, or in a chink far up the cliffs in spots absolutely inaccessible. We have found the nest in a great variety of situations-amongst beds of campion and sea-pink, in a deserted Puffin-burrow, in a hole in a ruined wall, and within a few inches of a Herring Gull's nest! The materials vary a good deal in certain districts, and appear to depend upon whatever is most readily obtainable. In some places 
dry grass is almost entirely used; in others this is mixed with moss and bits of dry sea-weed. It is lined with horse-hair wherever the birds can obtain it, but in localities where this material is wanting fine dry grass is used in its place. A nest we once found upon the Farne Islands had a single Gull's feather in the lining; whilst at St. Kilda we noticed that the birds obtained horse-hair for a lining from the snares set in the cliffs to catch Puffins. The eggs are four or five in number, and are greenishor brownish-grey in ground-colour, mottled, sprinkled and blotched with olive-brown or reddish-l $\mathbf{r}$ Jwn, and paler markings of greyish-brown. On some eggs a few dark lines and streaks may be noticed. The bird is a close sitter, but when disturbed becomes anxious for the welfare of its nest, and is soon joined by its mate, the two flitting restlessly about and calling plaintively.

The Rock Pipit during most of the year feeds almost exclusively upon small worms, insects, larvæ and tiny molluscs. Many insects are secured whilst the bird is chasing them in the air. It also obtains much food on the rocks at low water. During autumn and winter small seeds are eaten.

The Rock Pipit has the general colour of the upper parts olive-brown, streaked with darker brown, except on the rump; the eye-stripe is indistinct and buffish-white ; the wings are brown, the wing-coverts tipped with white; the tail is dark brown, with the 
light pattern of the outermost feathers smoke-brown, and the next tipped with brown. The general colour of the under parts is pale buff, shading into nearly white on the throat, and into olive-brown on the flanks, spotted and streaked with blackish-brown. The female closely resembles the male in colour; and the nestlings are similar to the adults, but the under parts are more profusely streaked. The total length of this bird is about six and a half inches, 


THE LARKS 



\section{THE LARKS}

WITH the larks we again come to a group of birds containing singers of surpassing excellence. The homogeneity of this family is strongly asserted by the universal character of the scutellated hind tarsus, a peculiarity which divides off the Larks from the other Passeres. Tested by the character of the nestling plumage the Larks are apparently an inferior group to the Pipits, for the young are profusely spotted; but as singing birds their superiority is enormously greater. There are upwards of seventy species of Larks, according to the latest authorities, and about half as many again of local forms, or climatic races. The Larks are essentially an Old World group, and most abundantly distributed over Europe, Asia and Africa. One species is found in Australia, another in South America, and another (with several allied races) in North America. The typical Larks are all birds of sober plumage, but some of the Horned Larks are a little more showy 
in this respect. The Larks are essentially a musical family ; indeed we feel justified in the assertion that no other known birds excel certain species of the present group in their splendid vocal attainments; and of these fine singers we can fortunately claim two of the very best. Of the extra British species several at least deserve brief notice. One remarkable species is the Crested Lark (Galerita cristata), which possesses a sweet and varied song, uttered generally when the bird is standing on the ground. In India this Lark is said to be highly prized for its vocal powers, being kept in a darkened cage, where it is said also to imitate certain sounds. The Calandra Lark (Melanocorypha calandra) is another pleasing songster which we had the pleasure of hearing during our journey in North Africa. It is neither so prolonged nor so beautiful as that of our own Sky-Lark, but the bird is a very industrious singer, and is incessantly rising from the herbage to warble for a few moments and then to drop down again. By some authorities this Lark is described as one of the finest songsters in Europe; and if the extent to which it is kept in cages in many South European cities be any indication of its musical attainments these must be exceptionally high. Lastly, we may mention the Shore Lark (Otocoris alpestris), another bird which repeatedly sings whilst standing upon the ground, but more frequently whilst careering about the air high above its nesting-places in the Arctic regions. 
The song is sweet enough, but it is of too short a duration, and is somewhat marred by the introduction of harsh notes. This song is often repeated several times during one ascent. We will now pass to a detailed consideration of the two British species. 


\section{THE SKY-LARK}

\section{Alauda ARVEnsis}

Tuis well-known and justly-famed bird is found in all parts of the British Islands, including many of the outlying islets, such as the Hebrides, the Orkneys and Shetlands. Upon the Continent the Sky-Lark's range is very extensive, the bird being found from the Atlantic to the Pacific. Of course over such a vast tract of country there is considerable variation in colour and size, and many local races or subspecies have been distinguished by naturalists. These we need not attempt to describe here. The Sky-Lark then breeds throughout Europe and Asia up to or a little beyond the Arctic Circle in the west, and about seven degrees lower in the east. Its breeding range also includes parts of North Africa, and the mountains of Persia, Turkestan, Mongolia, the Amoor, and Japan. Its winter range includes South Europe, North Africa, Asia Minor, Greece, Palestine, Persia, North-west India, and North China. 


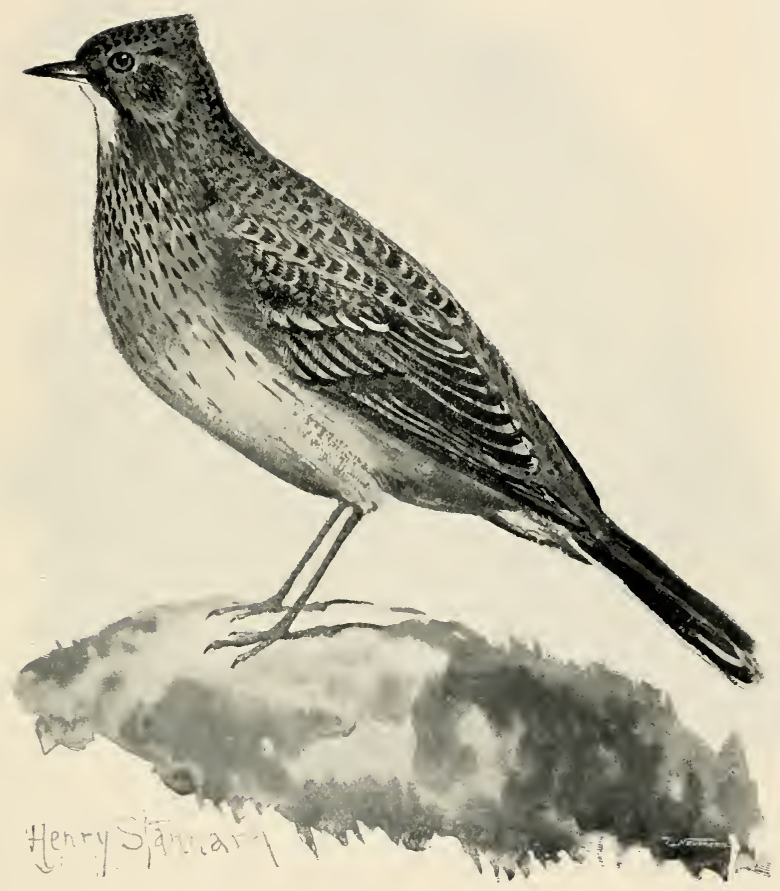

SKYLAKK 



The migrations of the Sky-Lark, especially in autumn, are by no means the least interesting part of its history. Each autumn it pours into Western Europe and across the North Sea into our islands in numbers that can be described only as amazing. During October and November millions of this bird must enter our eastern counties or sweep along the British coasts of the North Sea on their way to winter quarters still further south. Day after day, and night after night, this stupendous migration of Sky-Larks goes on, the birds appearing in neverending flocks. There can be little or no doubt that the birds that breed in our islands are sedentary; they become gregarious to a great extent in autumn and winter, and are subject to a certain amount of local movement, especially from the more elevated haunts, but this seems all. The Sky-Lark is perhaps the best known, although by no means the most familiar, of all our native birds, and finds a place in our hearts and our literature such as no other species can ever fill. It has found more favour with our poets than any other British bird; whilst as a cage-bird from England to Japan it is universally esteemed. In our islands the chief resorts of the Sky-Lark are the open fields, and, less frequently perhaps, the breezy uplands, the commons and the moors. It delights in districts comparatively free from trees, and is always most abundant on the highest land in every 
locality it frequents. The Sky-Lark is a thorough ground bird, living for the most part upon the ground, rearing its young upon the ground, and drawing almost its entire sustenance from it. It cannot be called a particularly shy bird, but it is one that does not permit of a very close approach, unless when skulking in the herbage; then it often remains in the cover until almost trodden upon before it rises with a very musical double note. It is seldom or never seen to perch in a tree or upon a hedge; it lives upon the ground, where it runs about in a very Pipit-like way.

To some extent the Sky-Lark is a perennal songster; for very frequently, even in mid-winter, an exceptionally warm day will cause it to resume its long-lost music. But this bird is essentially a singer of the spring; at no other time of the year is it so full of music, nor does its matchless song pour forth in greater volume. The song flights of the Sky-Lark are very remarkable; no other British bird approaches them, not only for the altitude reached, but for the duration of the ascent. In March and early April, when sexual rivalry is strong within its tiny breast, the song of the SkyLark is heard to greatest advantage. Who amongst us, but has not lain down at some time or another amongst the long grass of the meadows, or the shorter herbage of the windy downs, during these warm days of spring to watch the Sky-Lark so:ır 
upwards and upwards, looking less and less as he climbs an invisible path on fluttering wings to the clouds? Everywhere (as we wrote of this bird long years ago), from the grass lands and the fields of grain, from the open downs, from the moors and the heaths, the Larks are rising; one after the other they go; fluttering, fluttering, fluttering, round and round, upwards in a spiral course two thousand feet or more into the sky, revelling in the freedom of the boundless air, bubbling over with song and happiness. Fainter and fainter gets the song; only its loudest strains now reach the earth; yet fainter still, until the sweeter notes are lost beneath the mighty dome of blue sky, and even the sweet singer himself is almost lust to view. Then the zenith of the flight is reached, and the bird descends once more; louder and louder now grows his music; gently, almost imperceptibly he falls; lightly and gracefully he comes, until within a few feet of the ground, when his trembling throat becomes silent, the tired fluttering wings are closed, and like a stone he drops into the green cover once more. Aerial movements are, however, by no means essential to the utterance of the song; the bird sometimes warbles just as sweetly upon the ground; whilst his voice in a cage cannot be accompanied by the soaring flight although often uttered with beating wings. The song of this Lark, if not presenting much variety, is composed of wonderfully clear notes, and is uttered so continu- 
ously, so rapturously, and in such a perfect torrent of melody, as to win our highest admiration. Each spell of song lasts from two or three to fifteen minutes. The song of the Sky-Lark ceases in the autumn moult. No bird is more popular as a captive; it bears confinement well, is easily tamed, and is an exceptionally free singer in its exile.

During the breeding season, which lasts from April to July, the Sky-Lark is not a very sociable species. Numbers may nest on a small area of ground, yet each pair keeps to itself. The SkyLark apparently pairs annually. The nest is always made upon the ground, amongst the herbage of the fields-grain by preference-and waste grounds, or the heather on the moors. It is somewhat small, and made externally of dry grass, dead leaves, and bits of moss, lined with finer grass, roots and horsehair. The eggs are from three to five in number, greyish or olive in ground-colour, mottled, spotted and speckled with olive-brown and grey. A rare variety is white in ground-colour, spotted and freckled with reddish-brown and pale grey. The female is a close sitter, like most birds of her group, and in leaving and returning to the nest has a habit of running for some distance through the herbage. This species is double-brooded.

The food of the Sky-Lark, in summer, consists of insects, larvæ and worms, but during the remainder of the year of seeds and grain. There can be no 
doubt that this species is of great service to the agriculturist in consuming vast quantities of the seeds of certain troublesome weeds, as charlock, thistle, groundsel, dock, and the like.

The Sky-Lark has the general colour of the upper parts brown, streaked with darker brown; the eye-stripe is buffish-white; the wings are brown with buff margins; the tail feathers are dark brown with buff margins, except the outermost pair which are almost uniform white, and the next pair which have the outer webs only white. The general colour of the under parts is buffish-white, darkest on the breast which is spotted and on the flanks which are streaked with dark brown. The female closely resembles the male in colour, but the nestlings are spotted on the upper parts with buff and black, and the under parts are buff thickly spotted with blackishbrown. The total length of the Sky-Lark is about seven inches. 


\title{
THE WOOD-LARK
}

\author{
Alauda ARBOREA
}

Although the Wood-Lark is very widely distributed over the British Islands it is nowhere common, and is decidedly one of the most local of our indigenous birds. It is pretty generally dispersed over the southern counties of England from Devonshire to Kent, and northwards to Gloucestershire, Buckinghamshire, and Norfolk. Beyond these limits its localness increases, although it may be traced here and there as far as the Lake District. In Scotland it is known only to have bred in Stirlingshire; whilst in Ireland, although said to be a resident, its distribution remains at present practically undetermined. There can be little doubt that in many localities the present species is overlooked. Outside the British limits we find the Wood-I,ark generally, yet still locally, distributed over Central and Southern Europe. In the west it is not known to breed regularly north of lat. $60^{\circ}$, whilst in the east the valley of the Volga appears to mark its northern and eastern limits. In the more northern districts it is a summer visitor 




$$
q
$$



only. In the south of Europe, in Asia Minor, the Caucasus and North-west Persia it is principally known as a winter migrant, but some ascend the mountains in these countries during summer. South of the Mediterranean, although perhaps best known during winter, it certainly breeds in Algeria and other parts of North-west Africa.

If the observer with but a slight knowledge of birds bears in mind certain very perceptible characteristics of the Wood-Lark he will not readily confuse it with any other species. These are its much shorter tail, giving the bird a very "dumpy" look, especially when flying, its partiality for wellwooded districts, and its constant habit of perching in trees. The favourite haunts of the Wood-Lark, however, are not woods-so far the bird's name is a misleading one, and "Tree-Lark" would be far more expressive. The bird loves to frequent open localities over which plenty of trees are scattered, and where the soil is of a dry sandy character. It is thus specially partial to heaths and commons, to fields adjoining woods, or with tall trees in the hedges, and to well-timbered parks. Like the Sky-Lark the present species is more or less gregarious or sociable during the autumn and winter, though never gathering into such vast assemblies, and often mixing with flocks of its commoner congener. During this part of the year the Wood-Lark is not seen to frequent trees very much; like the Tree Pipit its arboreal habits are 
almost entirely peculiar to the breeding season. Except when inspired by love it is as much a ground bird as any other of its relations, finding most of its food upon the ground, and invariably roosting upon it. When flushed, however, it very often seeks refuge in a tree, and in this respect shows a decided difference of habit from the SkyLark. It has the same skulking habits, hiding low amongst the herbage, rising when almost trodden upon, and running about with great nimbleness in quest of food or to elude approaching danger. In very early spring the Wood-Lark's habits change. the parties disperse over the breeding-grounds and errantry is over until the young are safely reared. Like the Tree Pipit the present species keeps very closely to a chosen haunt all through the spring and summer; and another point of resemblance is the method of its song.

The Wood-Lark is one of the earliest birds to regain its voice in spring, doing so in mild seasons as early as February. This Lark not only sings whilst perched on the trees and bushes, but often has some particular branch from which it rises into the air to warble. The bird does not soar so high as the preceding species, nor yet so rapidly; it is more addicted to circling round, floating as it were, or rising and falling just above the tops of the trees. The song is undoubtedly superior to the Sky-Lark's in many respects. It may not be so loud, but it is equally continuous; the notes are sweeter too, 


and in parts may almost be said to rival that of the Blackcap. The Wood-Lark is a most industrious singer; warbling early and late, often being heard at dawn, as well as in the evening gloom. The bird is almost a perennial singer, and may be heard in voice through the year, with the exception of a few weeks in mid-winter, and during the period of the annual moult. We remember the exceptional abundance of this Lark in some parts of Algeria, where we could count half-a-dozen birds in the air together all in splendid song. We also noted its unusual tameness, for birds would very often sit and sing on some low b:ısh within a few yards of where we stood to listen to them. The possessor of such a matchless voice is an object much sought by the birdcatcher, and has led to the bird's extinction in many places where it was formerly common.

The Wood-Lark breeds early, and as it is a doublebrooded species the reproduction season may be said to extend from March to June or July. We are of the opinion that this Lark mates for life, for each season pairs of birds will return to certain spots to nest. The nest is almost invariably placed upon the ground, sometimes on the barest turf, but more generally well concealed under bushes or tufts of coarse herbage. It is made externally of dry grass and moss, and is lined with finer grass and horse-hair. The eggs are four or five in number, and are white tinged with buff or green in ground-colour, spotted and dusted with reddish- 
brown and grey. On some eggs the markings are evenly dispersed over the entire shell, on others they collect into a zone, or even into a cap at the end. In its secretive actions at the nest this species closely resembles the Sky-Lark. The female appears to incubate the eggs, and during this period the male is in almost constant song.

The food of the Wood-Lark consists of small worms, insects and larvæ during summer, and for the most part of seeds in winter. The bird is specially fond of small beetles and worms. We should also state that the call-note of this Lark is a musical double one, very similar to that of the Sky-Lark.

The Wood-Lark has the general colour of the upper parts brown, all the feathers having dark centres except on the rump, and the upper tailcoverts; the eye-stripe is white; the wings are brown, the primary coverts being tipped with white; the tail feathers are brownish-black tipped with white, the outermost feathers smoke-brown marked with blackish-brown on the inner web. The general colour of the under parts is white suffused with buff, and streaked with brownish-black on the throat, breast and flanks. The female closely resembles the male in colour; but the nestlings are spotted above with black and buff, and the under parts are yellow profusely spotted with blackish-brown. The total length of the Wood-Lark is about five and a half inches. 



THE BUNTINGS 




\section{THE BUNTINGS}

None of the typical Buntings can perhaps be classed as songsters of high merit, but some at least of the more aberrant species possess vocal powers of considerable beauty The typical Buntings form a group nearly allied to the Finches, from which they are distinguished by their angular gape, the edges of the closed mandibles not meeting throughout their length, but forming a conspicuous gap midway between the gape and the tip. The palate is also furnished with a hard knob which serves as an anvil on which the seeds which compose their principal food are cracked open. It is impossible yet to give the exact number of species which may have to be included in the present family, but the more typical members of it may be set down as between forty and fifty. The majority of Buntings are found in what has been described as the Holarctic realm, or North America, Europe, and the northern half of Asia. Some species are found in Africa, parts of Southern Asia, and South America, but the 
family as at present limited appears to be unrepresented in the Malay Archipelago, Australia, and Oceania. Many of the Buntings are birds of showy or strongly contrasted tints. Of the extra British species specially noted for their vocal powers mention may be made of the following. One of the most melodious of these is the Lapland Bunting (Calcarius lapponicus), a bird which is commonly distributed during summer in the Arctic regions of both hemispheres. Seebohm, who had unrivalled opportunities for hearing the song of this Bunting, says that it reminds one both of the song of the Snow Bunting and that of the Tree Pipit. It is not a loud song, but the notes are musical and long continued. It is most frequently heard as the bird indulges in soaring flights like a Lark, being continued until the singer alights, gliding down to a perching-place on outspread wings and tail. A fact of exceptional interest is that the hen-bird possesses a song almost as rich as that of the cock. Of the Snow Bunting (Plectrophenax nivalis), the same naturalist records that the song is a low and melodious warble, similar to that of the preceding species, the bird flinging himself into the air like a shuttlecock, and descending in a spiral curve with wings and tail outspread, uttering his charming refrain meanwhile. The song of the Little Bunting (Emberiza pusilla) is described by Messrs. Alston and Harvie-Brown as more like that of a Warbler, whilst Professor Lilljeborg says 
chat it is very sweet, most nearly resembling that of a Robin, and uttered as the bird sits conspicuously on the top of a bush; whilst the song of the Yellowbreasted Bunting (Emberiza aureola) is said by the natives of Dauria to be the finest bird music heard in their country. Some of the more aberrant species in the family are also fine songsters, notably the Cardinal of North America, which in some places is justly termed the Virginian Nightingale. None of the British species are specially remarkable for their song; that of the Common Bunting (Emberiza miliaria) is most harsh and grating; but the music of others forms a pleasing variation in the music of the fields. 


\section{THE YELLOW BUNTING}

\section{EMBERIZA CITRINELLA}

THIs is by far the commonest Bunting in our islands, universally distributed, and breeding in all suitable localities, including the Orkneys and the Hebrides, but not the Shetlands. Outside our area the Yellow Bunting is generally dispersed over the European continent, as far north as land extends in the west, but in the east not beyond lat. $65_{\frac{1}{2}}^{\circ}$, whilst in Western Siberia, in the valley of the Obi, its northern limit appears to be lat. $64^{\circ}$. It is a resident in Central Europe, a summer migrant to the more northern areas, and only a winter migrant to the south of Europe, from the Iberian Peninsula to Asia Minor. Its winter range also includes North-west Turkestan and North-west Persia, but no part of continental Africa, although the bird is said to be a resident in Teneriffe.

The Yellow Bunting is one of the most showily dressed of our native songsters, easily recognized by its bright yellow crown. It is also very ubiquitous 


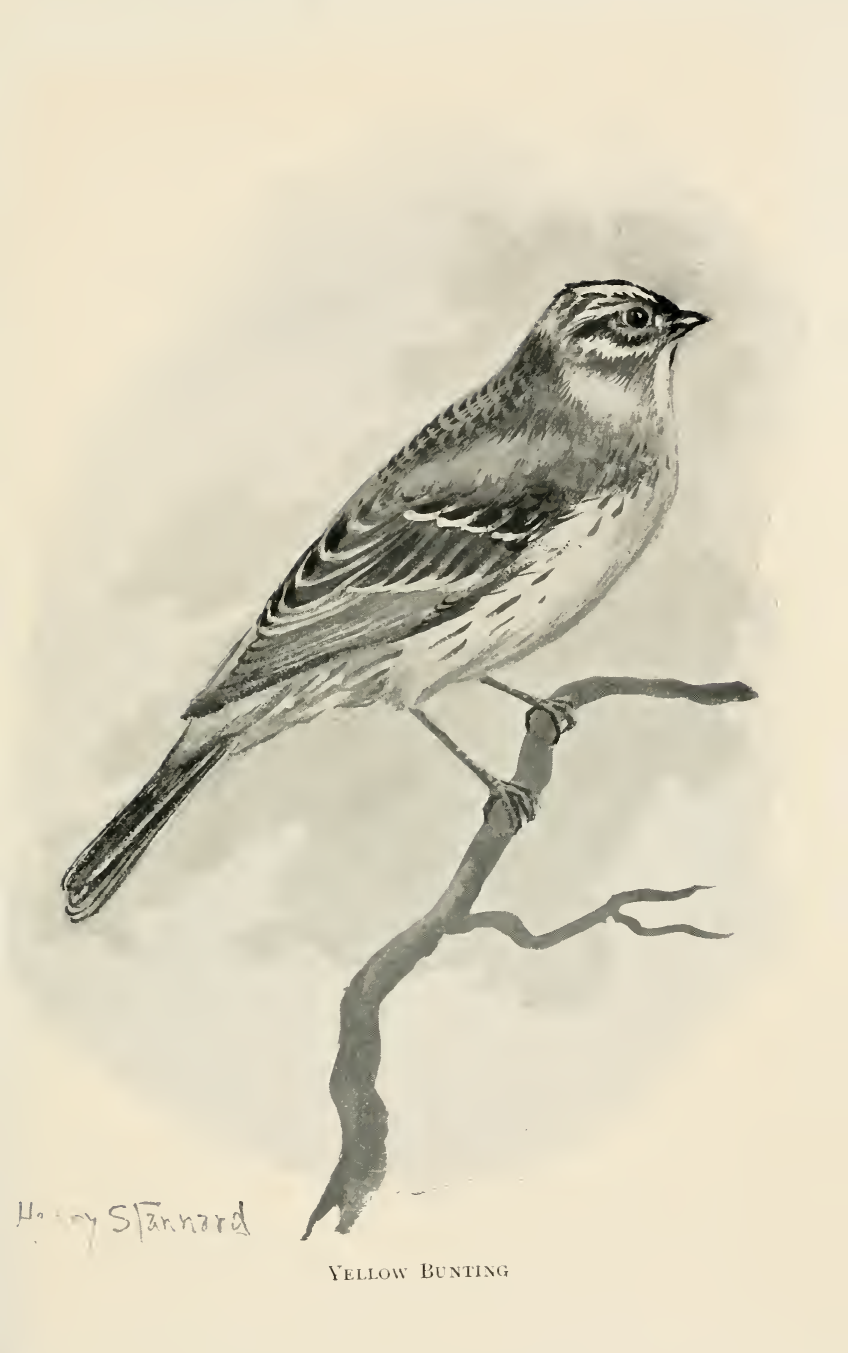





in its choice of a haunt, and may be met almost everywhere in agricultural districts. It is preeminently a bird of the hedgerows and the roadsides in country places, and one that is sure to be met with, especially in winter-time, in the vicinity of farm-yards, manure-heaps and ricks. The Yellow Bunting is a resident in the British Islands, but the sedentary population is considerably increased in autumn by arrivals from continental Europe. During the winter months this bird is to a large extent gregarious, and also socially joins assemblies of other hard-billed species. These flocks of Yellow Buntings frequent the newly-sown fields and the stubbles laid down with clover; whilst a heavy fall of snow will cause them to visit farm-yards and ricks, where they may often be seen clinging to the cornstacks, or searching for food on manure-heaps, or congregating about the barns and stables. If disturbed, the entire flock usually fly up into the nearest trees or hedges; sometimes the birds perch on the roofs of the buildings; and here they sit until one after the other they flit back to the feeding-place and recommence their search for food. Very pretty do these Buntings look amongst the snow, especially when a large flock is busily engaged in feeding, old birds fluttering here and there or rising up into the hedges, or sitting in the snow, where their richlycoloured plumage shows off to advantage. This Bunting runs more than hops, resembling a Chaffinch 
in its gait, whilst its flight, if somewhat unsteady, is quick and well sustained, and a flock will sometimes wheel in the air almost with as much precision as a bunch of Starlings. These aerial movements are often performed if a flock has been alarmed in a stiff wind, or just before the birds are about to settle in the trees and bushes where they are in the habit of roosting. As the spring draws near, these flocks of Yellow Buntings gradually disperse, and the birds spread themselves over the surrounding country to breed. The males are now in splendid plumage, and very handsome they look as they sit upon the topmost twigs of the hedges, or flit startled before us along the roadsides. At this season, too, the cocks are pugnacious, and rivals may often be seen chasing each other in fury through the branches, or from one tree or hedge to another. The season of song has now returned.

The Yellow Bunting is one of the first birds to regain its song in spring, and in the southern counties may be heard in full voice early in February. It is also one of the last to relinquish it in autumn, and continues in song until September. Its spring melody is, however, by far the most vigorous and persistent. The monotonous song of the Yellow Bunting is sure to succeed in bringing this species to our notice. Its very persistency arrests our attention; and as likely as not we shall find the brilliantly-dressed little singer sitting quietly upon 
the top of some hedge, or even high up some tree, repeating one little strain after the other with unwearying patience. The song consists of one rather sweet note uttered many times in rapid succession, concluded with two harsher notes, the last one continued much longer than the rest. These two notes at the close are sometimes omitted, but usually when the singer has been interrupted for some reason or other. Monotonous as this song undoubtedly is, it still sounds very agreeably amongst the first signs of spring; it is a homely strain, yet one that we may always associate with the opening year with honest pleasure. This song may be said to be punctuated with the prolonged call-notes cheechee-churrze. It is answered, too, by other Buntings in the vicinity, bird after bird taking up the song and uttering it almost in rotation. This Bunting is perhaps less shy when singing than at any other time; but this to a great extent seems to depend upon whether the bird is conscious of being seen. The singer is often hidden amongst the branches, and will continue repeating his music as long as you fail to notice his actual whereabouts, but when this is discovered, as likely as not he will immediately cease and retire to a safer distance.

The Yellow Bunting pairs early, and the nesting season begins at the end of March or beginning of April. The nest may either be made upon the ground or at some distance above it. Perhaps one 
of the most frequently chosen situations is the bank of a hedge, either at the root of the bushes or amongst the tall herbage; another favourite spot is in beds of nettles or in small bunches of briars and bramble through which tall rank grass is intergrown. Less commonly a gorse-bush or a low sapling is selected. The, nest is somewhat bulky, a good deal of material being collected, especially for the outer portion. It is made of dry grass, moss, roots and stalks of many kinds of plants, and lined with fine roots and horse-hair. The Yellow Bunting seems to be much attached to its nestingplace, often building in one spot for several seasons in succession; and continuing to lay egg after egg on the ground in the hollow whence the nest may have been removed. The eggs are four or five in number, and are white, more or less suffused with purple in ground-colour, streaked, spotted and lined with dark purplish-brown and grey. From the intricate manner in which the eggs of this Bunting are scrawled and scratched it is known in many localities as the "Writing Lark." Several broods appear to be reared in the course of the season, which extends to August. The bird is a very close sitter, and we have known her to feign lameness when scared from the nest.

The male Yellow Bunting has the head bright lemon-yellow, streaked with brown; the remainder of the upper parts is chestnut, streaked on the back 


and scapulars with dark brown; the wings are brown, the quills margined with yellow, and the innermost secondaries and wing-coverts have broad chestnut margins, and the latter with tips of the same colour; the tail is dark brown, the two centre feathers with reddish-brown margins, and the remainder with narrow yellow margins, the two outermost feathers with an oblong patch of white on the inner web. The general colour of the under parts is yellow, shading into olive on the breast, and streaked with rich chestnut on the breast and flanks. The female has much less yellow in the plumage than the male; the under parts are more thickly streaked, and the colour generally is dingier. The nestling plumage closely resembles that of the female. The total length of the Yellow Bunting is about six and a half inches. 


\section{THE CIRL BUNTING}

\section{EMBERIZA CIRLUS}

The Cirl Bunting is just as locally, as the Yellow Bunting is widely, distributed, and its breeding area is restricted to the southern half of England. Even within this area it is extremely local. Its breeding range may be said to extend from Cornwall to Kent, thence northwards through the counties of Surrey, Middlesex, Herts, and Bedford, and along the Thames valley to Gloucester, thence onwards through the valleys of the Avon and Severn to Warwick, Worcester and Hereford. Its extra British limits are proportionately restricted, embracing Central and Southern Europe, as far north as Dresden and as far east as the Crimea and Asia Minor. To North-west Africa it is a winter migrant, but a few apparently remain to breed there.

The Cirl Bunting was first distinguished as a British bird by Montagu at the beginning of the present century. He first discovered it in South Devonshire, and we can testify to the bird's abund- 




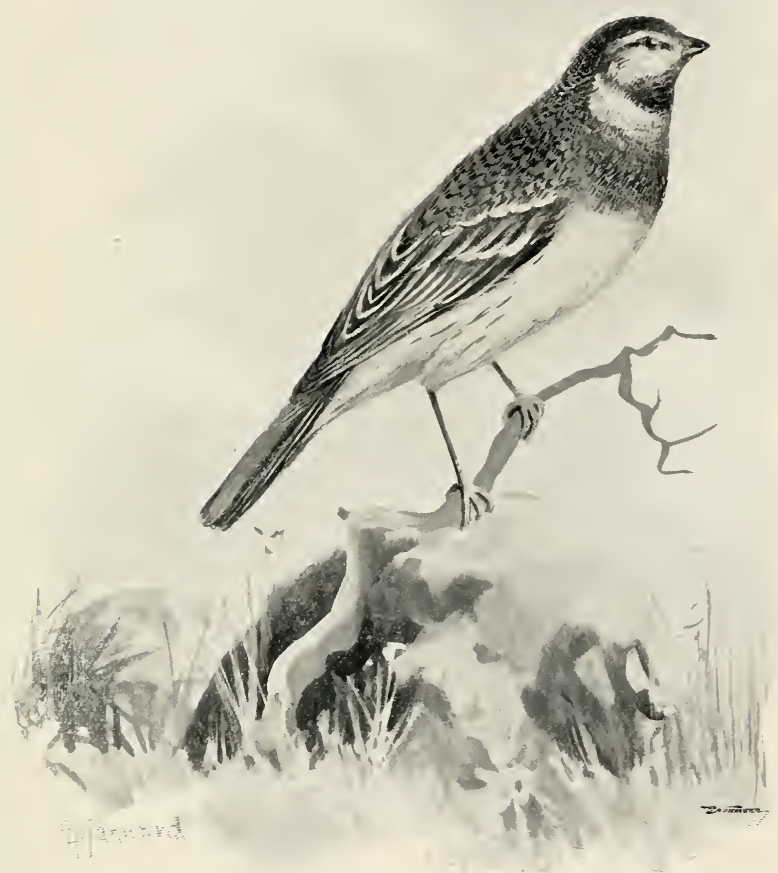

Cirl Bunting 

ance in that county nearly a hundred years later. Although the Cirl Bunting may not be quite so common in this country as the Yellow Bunting, it is by no means a rare bird, if a local one, and during winter may sometimes be seen in flocks consisting. of several scores of individuals. More often it is to be met with in flocks of Yellow Buntings, and the habits of the two species are remarkably alike. In autumn and winter we remark the same gregarious tendencies, the same preference for the company of other hard-billed birds, the resorting to similar haunts. It is said that the Cirl Bunting shows more preference for trees. This it certainly does, but during spring and summer only; in autumn and winter it may be seen as frequently upon the hedges and the ground as its commoner ally. We have repeatedly watched flocks of Cirl Buntings feeding on newly-manured fields and near ricks, fly up in scattered order into the nearest hedges, and remain there until their alarm has subsided, and they have dropped down again to feed one or two at a time. Neither is the bird any more shy at this season than the Yellow Bunting, and it will often allow one to approach it within a few yards with little show of fear. Upon the ground it runs to and fro or hops here and there like the preceding species; in fact the habits of one are an exact repetition of those of the other all the winter through. In spring, when the flocks break up, there 
is a slight difference in the habits of the two species manifest. The Cirl Bunting becomes more of a tree bird, rather more shy and skulking, and is certainly quieter, less demonstrative, and consequently more apt to be overlooked. It has also a habit of flying out of that side of a hedge or tree furthest away from the observer. As long as it thinks itself unseen it will remain chirping monotonously at regular intervals, but it seldom lingers long after it becomes aware that it is being watched. In spring and summer when flushed it usually flies from one tree to another, and is careful to hide itself away amongst the foliage. Showy bird as it is, it does not readily reveal itself, and often all our prying amongst the leaves is in vain, to discover the hidden and monotonous chirper.

The Cirl Bunting regains its song a little later in the spring than the Yellow Bunting. We have heard it in March, but it does not become at all general before April. This song is continued with varying frequency right through the summer, and finally ceases in the moulting season in July or August. On rare occasions we have heard this Bunting sing in autumn. $U_{p}$ to a certain point the song closely resembles that of the Yellow Bunting, but it wants the two concluding notes which are such a feature. It is in fact a Yellow Bunting's song when that bird has been disturbed before it could complete it. We do not remark the 


same persistency however in the Cirl Bunting's music ; it is more fitful ; and often for days together not a bird will give voice if cold windy weather prevails, although the Yellow Bunting will continue through it all. The Cirl Bunting's song is just one of those simple little refrains that punctuate the vernal chorus of more gifted vocalists; not much in itself, yet a pleasing if a minor variation in the music of the fields at this delightful period of the year.

The Cirl Bunting's resumption of song is a certain sign that the breeding season of this species is once more approaching. Its favourite breeding haunts are agricultural lands, gorse-coverts, and waste grounds or commons where plenty of trees and brushwood occur. So far as Devonshire is concerned we do not remark any particular difference in the summer haunts of this and the preceding species; both birds may be found nesting within a stone's-throw of each other. The nest is generally well concealed, and built either in a low gorse-bush, amongst briars and brambles, or on a bank of a hedge amongst the luxuriant growth of flowers and tall weeds; we have seen it at the bottom of a hedge wedged in between the stems. It is usually placed close to the ground, if not actually upon it, but is occasionally built as many as six feet above it. It is made outwardly of dry grass, roots, straws, leaves and moss, and lined with finer roots and hair. Sometimes the latter is entirely omitted. The 
eggs are four or five in number, bluish or very pale greenish-white in ground-colour, spotted and streaked in the usual Bunting style with very dark liver-brown. Two broods appear to be reared in the year, the breeding season lasting from April or May to July.

The food of the Cirl Bunting is composed of insects and larvæ and small seeds in summer, and seeds and grain of various kinds in winter. Montagu remarked that the young are largely fed on grasshoppers, and it may be that the presence or absence of this insect in certain districts to a great extent determines the distribution of the Cirl Bunting. The usual call-note of this species is a shrill tsip or tsit monotonously repeated, sometimes in quick succession, sometimes more deliberately.

The Cirl Bunting is very similar to the Yellow Bunting in general appearance, but differs from it in the following important respects. The head and nape are olive-green, the feathers of the former with black centres; the rump and upper tail coverts are also olive-green with dusky brown streaks; there are also yellow stripes above and below the eye; whilst from the base of the bill to and beyond the eye is a dark brown stripe; the smaller wing-coverts are olive-green. The throat is black, below which is a broad patch of yellow; the breast is olive-green shading into chestnut; the remainder of the under parts are yellow, darker on the flanks which are 
streaked with brown. The female closely resembles the female Yellow Bunting, but there is no trace of yellow on the head; the under parts are darker and more streaked, whilst the rump and upper tailcoverts are olive instead of chestnut. The nestling plumage resembles that of the female, but is even much duller still. The total length of this Bunting is about five and a half inches. 


\section{THE REED BUNTING}

\section{EMBERIZA SCHENICLUS}

THis pretty Bunting is another widely dispersed if somewhat local species. It is found in nearly all suitable localities throughout the British Islands, including even such remote and comparatively barren districts as the Hebrides and the Orkneys, although it is only a rare abnormal migrant to the Shetlands. Outside our area the Reed Bunting occurs in most parts of Europe, reaching as far north as the limits of forest growth, and as far east as the valley of the Yenesay, possibly beyond. To North Africa, Greece, Asia Minor, Turkestan and North-west India it appears to be a winter migrant only. Owing to the presence of several closely allied races or subspecies it is difficult to define the exact eastern limits of the typical Reed Bunting; but we may assert that in one form or another it is found in most parts of the entire Palæarctic region, south of the limits of forest growth.

This bird may very aptly be termed a "water-side" Bunting, its favourite haunts always being near to 




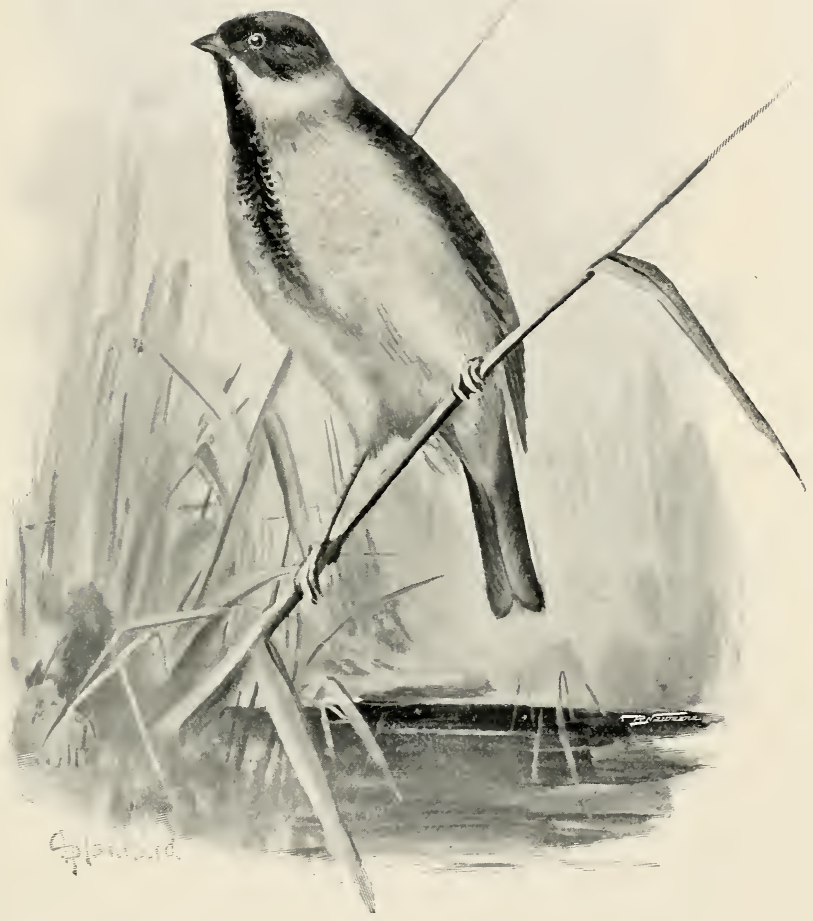

Reed Bunting 

water of some description. It is a frequent resident in and about large brick and clay fields, loves the banks of reed-fringed, slow-running rivers, ponds and canals; whilst in more remote localities it may usually be found on rough swampy ground and marshes. We remember to have found the Reed Bunting very common in certain bogs in Skye, where it was a most familiar species, frequenting the rough ground just outside the huts of the crofters, tame and confiding as the House Sparrow in more cultivated districts. It is by no means a shy bird, and it may often be seen clinging to some tall weed in a Stonechat sort of way, taking short flights from one stem to another, and looking very conspicuous in its strongly contrasted black and white dress. During summer this Bunting is generally met with in pairs, and very pretty lively little birds they are, ever and anon taking short flights or perching in the most exposed situations, seeming to court observation and notice. Frequently they may be seen clinging to some reed or willow, which bends nearly double under their weight, hanging over the water. If approached too closely they retire in undulatory flight still further down the river-side and again alight to await our advance. Again and again this may be repeated, until at last the birds make a détour across the water and return to their original starting-place. In autumn the birds become more or less gregarious and social, often consorting with other Buntings and with Larks. 
They are now seen very frequently in localities far from the water-side, especially during severe weather, when they will visit farm-yards, manure-heaps and sheep-folds. We have seen them with Yellow Buntings about the ricks, and they may often be flushed from the fields and hedges at that season. Although the Reed Bunting is decidedly a resident in the British Islands, subject of course to some local movement, there can be no doubt that many migratory individuals of this species enter our area in autumn from various continental localities.

The Reed Bunting is not a very remarkable songster, still his little refrain is a welcome one enough in the haunts he frequents, and in a great many cases is almost the only bird-music the locality can boast. This song commences at the end of March or early in April, and is continued until nearly the close of summer. It is a usual Bunting song, a double note repeated rapidly several times and concluded with a prolonged and harsher one. This is repeated again and again at intervals the livelong day, as the bird sits quietly on a wall, a telegraph-wire, a low bush, a tall weed, or the bending stem of a rush, or willow twig. We have never heard it uttered as the bird flew. It has been stated that the Reed Bunting occasionally mimics the notes of other birds, but we are more disposed to think that whatever resemblance can be traced is due exclusively to coincidence.

The Reed Bunting pairs almost as soon as it 
regains its song. Gregarious and social instincts remain in abeyance during the breeding season, which lasts from April to July, and each pair of birds keep to themselves and to a particular haunt. The nest for the first brood is commenced about the middle of April in our southern counties, but not until a month later in the northern ones. It is built on or very near the ground. A favourite situation is in the centre of a tuft of rushes, or sheltered by a hassock of sedge; less frequently a site is chosen on the banks of the water, amongst tall grass and other herbage. Nests have been found on tufts of reeds several feet above the water; others several feet above the ground in spruce firs. Externally the nest is made of dry grass, moss, broken bits of reeds and flags, and dead leaves; it is lined with fine grass, hair, and the dry flowers of reeds. Although loosely put together it is neatly finished inside. The eggs are from four to six in number. They vary from pale olive to pale buff in ground-colour, often with a purplish tinge, boldly as well as delicately spotted and streaked with dark purplish-brown and grey. These pencillings are not so intricate as, and are shorter and thicker than, those on the eggs of the Yellow Bunting. The hen-bird is a close sitter, and will sometimes feign lameness when flushed from the nest-a trick which the cock-bird occasionally joins in. The latter often betrays the whereabouts of the nest by sitting and singing close to it. 
The food of the Reed Bunting in summer is composed of insects and larvæ, small molluscs and seeds; in winter seeds and grain are the staple fare. The young birds are exclusively reared on an insect or "soft" diet. The call-note of this Bunting is a prolonged and very harsh seese, and is very like a common note uttered by the Greenfinch.

The adult male Reed Bunting has the entire head and throat black; a broad white stripe extends from the base of the lower mandible and joins the white on the breast and a white collar which passes completely round the back of the neck; the general colour of the remainder of the upper parts is chestnut, becoming grey on the rump and upper tailcoverts, each feather with a broad blackish-brown centre; the wings are dark brown, margined with chestnut-red; the tail feathers are black (except the two centre ones which are coloured like the back), with oblique white patches on the two outermost pairs. The general colour of the under parts is white, tinged with grey on the breast, and streaked with brown on the flanks. The female is much less showy, wanting the black head and throat, the head being reddish-brown streaked with darker brown; the eye-stripe is pale buff, the under parts are more streaked, and the white moustachial line of the male is replaced by a brownish-black one. The nestling plumage is similar to that of the female. The total length of the Reed Bunting is about six inches. 




\section{THE FINCHES}







\section{THE FINCHES}

A mongst the typical Finches we find many songsters of exceptional power and beauty. They form a homogeneous group characterized by a strong stout conical bill and the possession of nine primaries only in the wing, the bastard or first and generally minute primary quill being wanting. The present family is a very extensive one, numbering several hundreds of species, which are distributed throughout the world, with the exception of Australia and the Pacific Islands. The more typical Finches are chiefly found in the temperate and northern portions of the Old World, but the limits of the family are by no means clearly defined, and much diversity of opinion exists respecting them. The Finches are certainly showy birds; and even amongst British species some are of very striking and pleasing colouration. Of the extra British species which are exceptionally good vocalists we may proceed to mention the following, some of which, however, enter our area as abnormal migrants. The Pine Gros- 
beak (Pinicola enucleator), for instance, possesses a melodious, flute-like song ; whilst that of the Scarlet Rose-Finch (Carpodacus erythrinus) is so strikingly distinct that, according to Seebohm, it cannot be confused with that of any other bird, and is a loud clear whistle, composed of several very sweet notes. The singular Desert Finch (Erythrospiza githaginea) also possesses an exceptionally fine song which Dr. Bolle thus poetically describes: "A note like that of a small trumpet trembles through the air and vibrates continuously; and if we are very attentive we shall hear, just before and just after it, two gentle, light notes ringing like silver bells through the still desert, or the almost imperceptible chords of an harmonium played by unseen hands. Again it changes, and this time its notes resemble the deep croak of the green frog of the Canaries, but less coarse, hastily repeated one after another." Again the wild Canary (Serinus canarius) has a very sweet and powerful song ; but in this case, we may remark, that captivity and careful breeding have improved the voice of this Finch to a degree that is simply astonishing. The Finches as a rule are by far the most satisfactory cage-birds, and their vocal powers, in most cases, are very much improved in captivity. Some of these birds not only become exceedingly tame, but are capable of being taught various airs; whilst judicious cross-breeding often results in increased power and brilliancy of song. The Canary 


and the Goldfinch may be instanced in support of this statement, some of the cross breeds between these two species being remarkable for their vocal powers. We will now glance at our favourite songsters amongst the Finches which are indigenous to the British area. 


\section{THE GOLDFINCH}

\section{Carduelis elegans}

Tirs elegant and beautiful Finch is much rarer and far more locally dispersed now than it was say fifty years ago. To a very great extent its scarcity in or even entire absence from many districts where it formerly was common, is chiefly due to the wholesile way in which it has been netted and snared by bird-catchers Less than forty years ago it was recorded that more than one hundred and thirty thousand (chiefly cocks) Goldfinches were caught near Worthing alone every year! The late Henry Swaysland assured us, many years ago, that when a boy he could take as many as five hundred of these Finches in a single morning. Few birds could stand such wholesale destruction long, and the wonder is that the Goldfinch maintains its position as a British, or even as a European species at all! Another cause of the decreased numbers of this bird is the reclamation of many waste lands which has destroyed favourite haunts and almost unlimited supplies of 


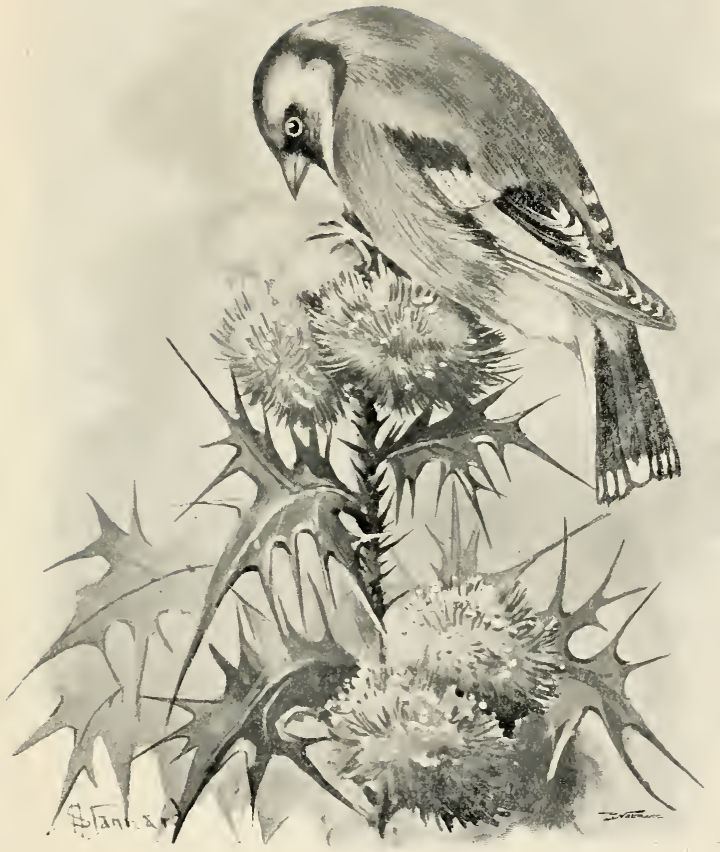

GOLDFINCH 

food. We are assured by an experienced birdcatcher that thirty years ago in this part of Devonshire the Goldfinch bred in almost every orchard; now it is one of our rarest and most local birds. All this is sad reading, and it is a source of keen regret that so handsome and once so familiar a bird has now become so rare. The Goldfinch, in limited numbers, may still, however, be said to breed locally in all parts of England, becoming rarest in the extreme north and west. In Scotland, although it is known to breed as far north as Caithness, it is even more local, yet said to be increasing in numbers in the south. Although widely dispersed in Ireland it can nowhere be called abundant, and is very local. The extra British range of the Goldfinch comprises the greater part of Europe, nearly up to the Arctic Circle in the west, five degrees lower in the east. In the south it includes the Canaries, Madeira and North-west Africa, Pa'estine, Asia Minor and Persia. In the extreme north the Goldfinch is a migrant ; in Egypt it appears to be found in winter only; whilst in many southern localities (as for instance in Algeria) it ascends mountains to breed. East of the Ural Mountains in Siberia and Turkestan, two closely allied Goldfinches occur, one of which is probably only subspecifically distinct from the European form.

The Goldfinches living in the British Islands appear to be sedentary, if subject to a varying 
amount of local movement. Formerly vast flights of this Finch came to our area in autumn from the Continent, but the numbers now-a-days are limited, due to causes we have already indicated. The favourite haunts of the Goldfinch are in the cultivated districts, in orchards and large gardens and shrubberies, as well as on those farm-lands where tillage is not practised to the extent of destroying all the hedges, and of improving away the various weedgrown corners and bits of rough waste pasture. During autumn and winter this species may often be met with in small flocks or parties on rough unenclosed land, where they may be seen clinging to the tall dry plants, such as thistles and docks, busily engaged in extracting small seeds. Although somewhat wary, they can scarcely be considered shy, and often allow us to approach them sufficiently close to watch their movements. Perhaps the Goldfinch looks best amongst the snow, flitting from one tall dead weed to another, displaying its brilliant colours, which contrast beautifully with the white surroundings. Particularly charming does the Goldfinch look when fluttering before a thistle-head, scattering the downy seeds in its efforts to pick them out ; or when clinging to a brown withered dock plant, standing high above the glistening snow-drift, with halt-open wings to steady itself. It is a restless active creature, ever in motion, flitting in drooping flight along the hedye-side or across the open ground to 


every tall plant likely to yield the seeds on which it subsists. The Goldfinch is perhaps least seen on the ground of all our common Finches, the peculiarity of its food confining it to bushes and tall plants. If alarmed it often aiights in trees; its visits to the ground are chiefly confined to a search for the seeds of such weeds as groundsel, plantain and dandelion. The Goldfinch is rather a noisy bird, if in a quiet sort of way, and its peregrinations are generally accompanied by its twittering call-note. In early spring the parties of Goldfinches disband and retire to various haunts to breed.

At this season, too, the charming little song of the male begins to be heard amongst the orchards and hedges. This song though not very loud nor long is exceptionally sueet. The bird is a somewhat coy singer, soon silenced if disturbed, and delighting to sit and warble amongst the cover of its haunts. We never heard the Goldfinch's music to better advantage than in an Arab garden in Algeria, where the apple trees abounded with these birds, exhibiting a tameness unknown in England, three or four singing in concert or rivalry at a time. The Goldfinch continues in song through the summer to August, but its music is more desultory and less stirring in the later months. We always think it sounds the best when the apple trees are in full bloom.

In many localities the Goldfinch may be seen in pairs right through the autumn and winter; but 
whether the majority remain thus united, or pair in early spring we are at present unable to say. The exquisite little nest is often placed in a fork of some lichen- or moss-covered fruit tree, sometimes in an evergreen, sometimes in the thick hedge that surrounds a garden or an orchard. It is small and neatly made, composed externally of dry grassstems, moss and roots, these materials being bound together and garnished with spiders' webs, cocoons and bits of lichen; it is warmly lined with vegetable down, hair, and feathers. The interior measures about two inches in diameter and one inch in depth. The eggs are four or five in number, white with a greenish tinge in ground-colour, spotted and speckled with dark brown, paler brown, and grey. Throughout the nesting period the Goldfinch is certainly a secretive and retiring bird, seldom betraying the whereabouts of the nest by its actions. Two broods are occasionally reared in the season.

The food of the Goldfinch in summer consists largely of insects and larva; it is probable that the young are reared exclusively on such a diet. During the remainder of the year seeds of various kinds, especially of the commoner weeds, are almost its sole support.

The Goldfinch has the lores, the feathers at the base of the bill, the crown and a band extending from it behind the ear-coverts, black; the forehead and throat are crimson; the remainder of the upper pat ts 
is chocolate-brown, shading into white on the upper tail-coverts; the quills are black, tipped with whitc, and broadly barred with bright yellow; the greater wing-coverts yellow; the tail is black, the two or three outermost feathers on each side having a white spot on the inner web, and the rest tipped with white. A patch on the nape, the sides of the head, and the under parts below the throat are dull white, shading into brown on the breast and flanks. The female resembles the male in colour, but is not quite so brilliant in hue; the nestling wants the black and red on the head, and the under parts are browner. The total length of this bird is about five inches. 


\section{THE LINNET}

\section{LINOTA CANNABINA}

THE well-known and favourite Linnet is one of the most widely distributed of British bircls. It is commonly dispersed over England, IVales, Scotland and Ireland, even extending to many of the Hebrides and the Orkneys, but not to the Shetlands. In the wilder and more remote northern and western districts it is more local, and in some places appears entirely to be replaced by the nearly allied Twite. The Linnet is a widely ranging continental species also, being found in all suitable localities throughout Europe and Southwestern Siberia as far east as the Altai mountains. In West Europe, however, it does not appear to range north of lat. $64^{\circ}$; in East Europe five degrees lower still. It is resident in the Canaries and Madeira, as well as in North-west Africa, but in North-east Africa, as far south as Abyssinia, it is a winter migrant only; whilst in the extreme north of its range it is a summer migrant. 




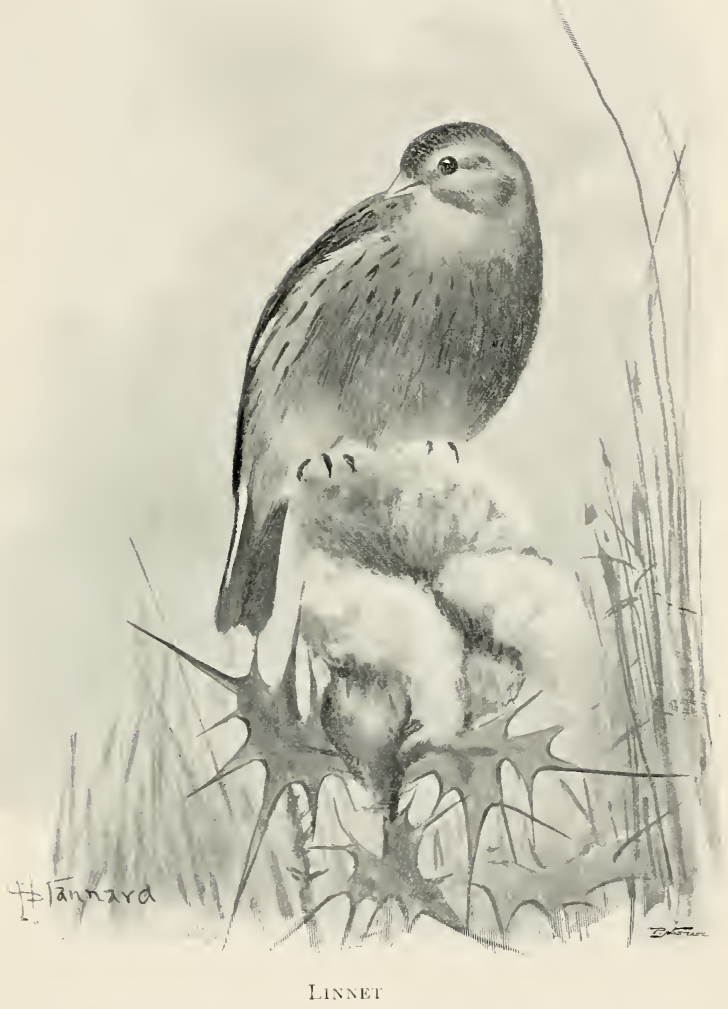



The Brown Linnet, "Gorse Linnet," or " Lintie," as it is otherwise known, is a resident in the British Islands, but subject to much local movement. Its numbers are also increased in autumn by large flocks from the Continent; and some authorities assert that at the same season a considerable southward movement takes place amongst our indigenous birds: this we are inclined to doubt.

The same adverse circumstances that have so disastrously reduced the Goldfinch in numbers seem to have affected the Linnet in a similar way. It is certainly not as common in many places as it used to be; and this can be traced to the wanton wholesale capture by bird-catchers, and the reclamation of much waste ground which was formerly its favourite retreats. The haunts of the Linnet vary somewhat according to season. In autumn and winter they are stubbles, rough pastures, commons, and the unenclosed lands near the sea, particularly "saltings"; in spring and summer the more upland districts are the chosen retreats, gorse-coverts, heaths, the rough grazing grounds near the moors, and the moors themselves, especially where they are sprinkled with bushes, thickets, and stunted trees. During autumn and winter the Linnet is more or less gregarious, some of its gatherings at these seasons numbering hundreds of individuals. The bird is not seen much in the company of other Finches; sometimes 'Twites and Redpoles 
will associate with a fl ck of Linnets. These flocks frequent any ruugh ground where they can obtain food, the birds feeding a guod deal upon the ground; they are rather wild, and if disturbed rise in a compact twittering throng, bunching well together, and probably settling on the top of some distant tree, where for long they will keep up an incessant twittering. As the birds recover from their alarm they return in twos and threes and little parties to the favolirite feeding-place, and eventually the entire flock is busily engaged in search of seeds. If disturbed precisely the same actions will be repeated. Flocks of Linnets will often remain for weeks in one locality if the food supply chances to be an abundant one. The Linnet's partiality for the society of its own kind is even strongly marked during summer, for numbers of pairs will frequent the same gorsecovert.

The Linnet continues in flocks until the vernal equinox, and regains its song a short time before the winter gatherings disperse. Perhaps it is at this time the song of the Linnet is heard to best advantage; certainly his early vernal music is the best. The general effect is very charming when the males of an entire flock warble in concert, as they often do in March or early April. Here in South Devon flocks of Linnets may be met with in the gorse on the cliffs by the sca every spring; 
and it is no uncommon thing for a dozen males or more to sing together; and exquisitely beautiful they look, perched on the topmost sprays with crimson breasts distended in the bright sunshine. The song is not a loud one, but it is very sweet and warbling in parts, and is all too short for our full enjoyment. The Linnet is by no means a frequent songster; he may be heard, and sometimes very persistently, through the breeding season; but it is in the pairing time, just before and just after the flocks disperse, that he seems to be most filled with melody. The call-note of the Linnet is a shrill and somewhat musical twitter; whilst the cry heard between the sexes is a plaintive tyezu-ec.

The Linnet appears to pair at least a month before it begins nest-building. The favo rite breeding-place of this little Finch is ground more or less thickly covered with gorse, broom, and thickets of brambles, briars, and low thorn-bushes. The nest is made frequently amongst the dense gorse, where its discovery is a matter of great difficulty; a broom-bush, or a thicket of briars is another favourite spot; whilst a young fir tree, or a crotch in a dense thorn are occasionally selected. In some places long ling is often resorted to. The nest is a very pretty one, made outwardly of bits of dead gorse, dry grass, moss, dead leaves, and perhaps a few slender twigs; and lined with a thick bed of hair, wool, the down from certain plants, and 
feathers. This lining is arranged very smoothly and neatly. The nest is seldom placed more than a few feet above the ground, sometimes quite close to it, and rarely upon the ground. The eggs are from four to six in number, pale bluish-green in ground-colour, sometimes almost white, spotted and speckled chiefly at the larger end with dark brown, paler brown, and grey. Both birds assist in incubating them, the female, however, doing the greater part. Very often the exact locality of the nest may be detected by the cock-bird persistently perching near it to sing. Two broods are generally reared in the season.

The food of the Linnet is principally composed of small seeds. The bird does not appear to be so much of an insect-eater as some of the other Finches ; and it is said even to feed its young on seeds which have been prepared by careful husking and sometimes partial mastication. The larger seeds and grain are not eaten to anything like the extent the smaller ones are, such as those of docks, thistles, plantains, chickweed, charlock, and so on.

The adult male Linnet has the fore part of the head crimson, the rest of the head, the nape, and the sides of the neck brownish-grey; the back is chestnut-brown, paler on the rump, each feather, including the wing-coverts and innermost secondaries, with an obscure dark centre; the upper tail-coverts are dark brown broadly margined with rufous-white; 


the quills are brownish-black, margined with white on the outer edge; the tail is brownish-black, margined with white, broadest on the inner webs. The breast is crimson, the belly and under tailcove ts are white, the flanks brownish-buff. The female is much duller than the male, having no crimson on the crown or breast. The nestling plumage resembles that of the female. Newly moulted birds have pale margins to the feathers, which in the cocks conceal much of their beauty, until abraded away in spring. The total length of the Linnet is about five inches and a holf. 


\section{THE TIVITE}

\section{LINOTA FLAVIROSTRIS}

THE Twite is one of our less familiar species, especially during the spring and summer, when its resorts are the moorland: This species occurs wherever there are suitable moors, from the Midlands, northwards to the Orkneys and Shetlands, and westwards to the Hebrides and St. Kilda. There are no moors on the latter group of islands, but they are a resort of the Twite notwithstanding. In Ireland the Twite is also widely dispersed over most of the elevated moors. Outside the limits of the British Islands the Twite has a most restricted range, being known to breed only in Norway, and even there principally near the coast. During winter it migrates southwards, chiefly down the extreme western districts, and rarely reaches any of the countries bordering the northern shores of the Mediterranean.

There can be little doubt that the Twites which treed within our area are sedentary, in the sense 


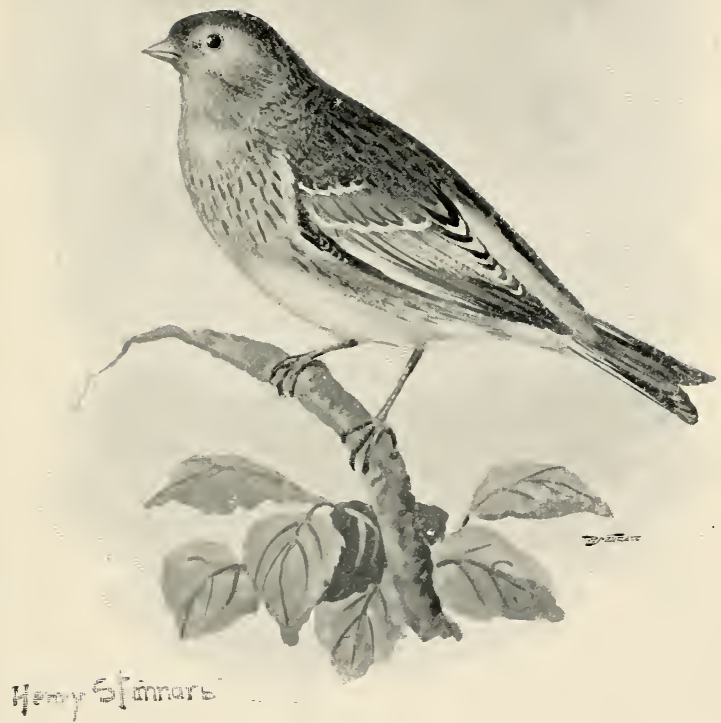

Twite 

of never leaving it. The bird is subject to a certain amount of internal migration from the moors to the lower and cultivated districts ; whilst in autumn considerable numbers enter our area from continental districts. It is a common migrant at Heligoland, both in autumn and spring-occurring in October and November, and again in March. The habits of the Twite, and during the winter, at least, the haunts it frequents, are very similar to those of the Linnet. At the approach of autumn it becomes gregarious; indeed we have noticed assemblies of this species as early as June, so that it seems probable the birls begin to gather as soon as nesting duties are over. Their favourite haunts at this season are weedy pastures and rough unenclosed lands, especially near the coast, and here in compact flocks they live, wandering little, so long as food can be obtained. They are not particularly shy birds, but if approached too closely the entire flock will rise en masse, twittering noisily to each other, and perhaps after wheeling round for a moment, will again settle and commence feeding; or, as often happens, betake themselves to some distant tree-top, where they will keep up a loud chorus of cries until they again light upon the ground, usually doing so in stragryling parties. Agra n and again they may be flushed with precisely the same results. This species appears to live principally upon the ground; it is comparatively seldom seen in hedges or bushes; it prefers a lofty situation when perched, 
and the ground seems to furnish it with most of its food. Early in the spring the Twites resort to the moors once more to breed, the flocks break up into pairs and disperse themselves over the brown wastes for the summer.

It is now that the pretty song of this Finch may be said to be heard at its best. As with the Linnet, we think the voice of the Twite sounds best in chorus-when several males are singing in concert, inspired by each other's rivalry; or perhaps better still when the cocks in an entire flock warble together, as they often do in March, whilst sitting on the tree-tops. The song bears a very striking resemblance to that of the Linnet; not perhaps quite so loud, but equally sweet, especially when uttered as a part-song in chorus. The Twite sings much during the early part of the breeding season; and in the wild haunts it frequents, where bird music is by no means a strong feature, its lively little strain sounds particularly grateful and pleasing. The Ring Ouzel and the Dipper, the Meadow Pipit and the Cuckoo are the other singers of these brown breezy uplands-none of them great musicians, yet their voices gladden, and are in full harmony with the surrounding scene. The call-note of the Twite is a shrill and oft-repeated twitter; but the note between the sexes in summer is a very characteristic one, a long-drawn twa-ite, hence the bird's trivial name.

Although the flocks of Twites begin to disappear 


from the lowlands in March and April, the bird is not such an early breeder as the Linnet, and seldom begins nest-building before May. Its breeding-places are almost exclusively confined to the vast tracts of heather and ling. The nest is generally placed amongst the heath, only a few inches above the ground, and very often upon the ground itself. A favourite spot is on the edge of a steep bank which slopes down to a rough cart-road or sheep-track. Occasionally it is found under a piece of turf, more rarely still in a bush. It is made of fine twigs, grassstalks, moss, and roots, lined with finer roots, vegetable down, wool and feathers, sometimes one kind of material predominating, sometimes another, whichever chances to be most common in the locality. It is a very artistic-looking little nest, very round inside, rather deep, neatly finished, and the lining wonderfully smooth. The eggs are from four to six in number, pale bluish-green in ground-colour, spotted and speckled, and occasionally streaked with reddish-brown and grey. The Twite sits closely, and when disturbed is often joined by its mate, the two birds then flitting anxiously and restlessly to and fro. But one brood is generally reared in the season, and young and old appear to keep together until they join into a larger flock for the winter.

The food of the Twite consists of a great variety of small seeds; but in summer insects, especially beetles, are sought. There can be no doubt that 
both the Linnet and the Twite do incalculable good in ridding land of vast quantities of weeds, by consuming the seeds. Consequently their visits to the fields should be encouraged, and the farmer should on no account countenance their destruction either by snaring or shooting. Had farmers been more alert to their own interests and forbidden birdcatchers to enter their fields, neither the Linnet nor the Goldfinch would have decreased so enormously in numbers.

The Twite is very similar to the Linnet in appearance, but is smaller, and has a proportionately longer tail. It, however, wants the lovely carmine tints on the head and breast, but the male has a red rump like the Redpole. The general colour of the upper parts is reddish-brown, the feathers having dark centres; the wings resemble those of the Linnet, but the tail wants the broad white margins to the feathers, these being replaced by pale brown edges. The general colour of the under parts is pale reddish-brown, shading into white on the abdomen and under tail-coverts, and streaked on the breast and flanks with darker brown. The female resembles the male in colour, but is paler, and wants the carmine on the rump. The nestling plumage resembles that of the female. Adult Twites in autumn and breeding plumage are characterized by having a jellow bill. The total length of this Finch is about five and a quarter inches. 


\section{THE LESSER REDPOLE}

\section{LINOTA RUFESCENS}

The Lesser Redpole, one of the smallest of British Finches, and a favourite cage-bird, is a rather local species, especially during the breeding season. It is decidedly a northern species, but breeds in most suitable localities north of about lat. $52 \frac{1}{2}^{\circ}$. South of that limit it is much more local, though perhaps thought to be much rarer than it really is, especially in the extreme west and southwest. It breeds, however, in South Devon, if sparingly. In Scotland its distribution appears largely to depend upon the presence of birch woods and fir plantations. In Ireland it is equally widely if locally distributed, and commonest in the north. The extra British range of this Redpole is very limited, and confined practically to Western Europe. It breeds in West Germany, Belgium, Holland, and in the alpine regions of Styria, Savoy and Italy. Other very closely allied forms are found in the Arctic regions of both hemispheres, and are rare abnormal migrants to the British Islands. 
The Lesser Redpole appears to be a resident in our area, but like most Finches subject to a good deal of internal migration according to season. No migratory Redpoles appear to visit our islands in autumn ; and at Heligoland (although it has on one occasion been known to nest there) it is so exceedingly rare that but two or three examples have been obtained. The habits of the Lesser Redpole are very similar to those of the Linnet. In autumn and winter we remark this species in flocks upon the weed-grown pastures and waste grounds; or even more frequently perhaps amongst the birch and alder trees that fringe the streams. This little Finch not only frequents the ground in quest of food but the trees as well, and in the latter situation is often as agile and grotesque in the attitudes it assumes, as the Tits which often consort with it. Like most small birds the Lesser Redpole shows little fear of man; and whether upon the ground, or perched upon the adjoining hedges and trees, it suffers a close approach and observation of its ways. We have often wandered literally into the middle of a flock of Redpoles, on stubbles sown down with clover, and stood and watched the engaging little creatures almost at arm's-length searching everywhere for the small seeds. If alarmed the flock has a way of rising en masse, sometimes resorting at once to the nearest hedge or tree, but frequently wheeling round several times before settling again on another 


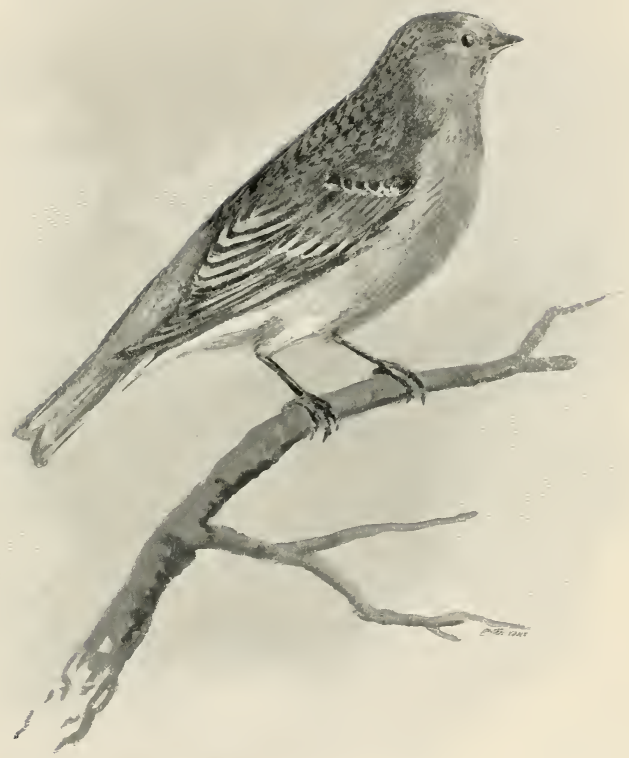

$\left[\quad t_{-}=\right.$

LESSER REDPOLE 

part of the field, or even precisely in the same place from which they were flushed a minute or so before. We have repeatedly noticed that a flock of Redpoles will remain in a district during the entire autumn and winter; and this bird is not given to so much erratic wandering as is generally supposed. If weed-covered ground is plentiful the birds will remain there. Their habits in the trees are very similar to their actions upon the ground. In November, when the alder trees are covered with ripe seed-cones, the Redpole in flocks may be seen exploring the branches, the entire company incessantly in motion, if disturbed rising into the air together and shortly after re-alighting, it may be in the same tree. The Redpole is also very frequently seen along the hedges where a dense growth of weeds is allowed to flourish by the slovenly farmer (we would not have him change his ways, for tidiness would lead to the banishment of many of our favourite birds), the birds clinging to the nettlestems, or the tall dry stalks of docks and thistles, scattering the husks on every side as the coveted seeds are sought. On the approach of spring these bands of Redpoles disperse to the breeding-places, and the cock-birds resume their song.

The song of the Lesser Redpole can neither be described as a striking nor a very musical one. As Seebohm says, truly enough, it is a song the charm of which cannot be analyzed. IVe both of us lived 
for many years in the same Yorkshire haunt of this charming little bird; indeed it used to nest every season within a couple of hundred yards of my door, we were therefore thoroughly familiar with its song; and yet, as so often happens, we differed somewhat in our estimate of its musical qualities. He describes it as a short and monotonous trill like the rattling of loose cog-wheels! We should rather compare it to that of the Linnet, a short twittering musical song in which some of the notes are particularly sweet and charming. We have stood and listened to the song of this Redpole times without number, and at a distance of but a few paces from the singer, and this is our matured opinion of it. The Lesser Redpole does not warble in concert to anything like the extent the Linnet does, and its voice is hushed as soon as the young are reared.

Although this Redpole pairs annually we have repeatedly remarked its great attachment to certain spots, in which to nest. Its breeding-places depend a good deal upon the nature of the country which it frequents. In agricultural districts the hedge-rows are the chosen places; in wilder localities, birch coppices, larch plantations, and thickets of bramble and briar, especially on the banks of the upland streams. Generally the nest is built at no great height, and a fork in the larger branches is the usual site. We have found it, however, as many as fifty feet above the ground in the tallest trees, 


especially elms where the foliage grows close to the thick limbs. Although the nest of this Redpole varies a good deal in beauty, some being much more exquisitely built than others, there is a charm about them all which brings this species into the very front rank of avine architects. Externally this nest is made of slender twigs, roots, moss and dry grass; whilst the lining consists of feathers, vegetable down, hair, and wool. The cup is very small and deep and round, yet finished in a remarkably neat manner. The eggs are from four to six in number, greenish-blue in ground-colour, spotted and speckled with purplish-brown and grey, and sometimes streaked with darker brown. Sometimes the colouring matter is distributed in a clouded or washed manner, with a few darker markings here and there. During the entire breeding season Redpoles are retiring in their habits, often nesting in a much-frequented spot without discovery ; and it is only when the branches are denuded of their leaves in autumn that the long-deserted home is seen. This Redpole generally rears one brood only in the season.

The food of the Lesser Redpole is largely composed of the smaller seeds, but in summer insects are also sought. The usual call-note of this bird is a shrill twit rapidly repeated; but the cry between the sexes sounds like the word henri whistled softly. The adult male Lesser Redpole has the general 
colour of the upper parts rufous-brown, each feather with a dark centre: the wings and tail are brown, the feathers having pale margins, the median and greater wing-coverts broadly tipped and the innermost secondaries broadly margined with pale buffishbrown. The forehead and crown are crimson, and the rump is tinged with the same colour. The general colour of the under parts is buffish-white shading into brown on the flanks, and into black on the lores and throat; the breast is flushed with crimson. The female resembles the male in colour, but lacks the crimson tint on the breast and rump. The nestling plumage resembles that of the female, but the under parts are more streaked, and there is no trace of the crimson on the head, or any other part of the body. The total length of this bird is about four and a half inches. 




\section{THE SISKIN}

\section{CHRYSOMITRIS SPINUS}

The Siskin is certainly far better known in a captive than in a wild state. In this respect it is certainly one of our familiar songsters, and we have no hesitation therefore in including it here, more especially as its habits in a wild state are by no means familiar to many persons who keep it in captivity. Not only so, but this species may possibly be overlooked in many localities, especially during summer. The Siskin is chiefly a northern species, especially during the breeding season, and so far as our knowledge of it at present extends, is one that nests exceptionally in England. Instances are recorded of its having done so in Durham, Cumberland, Westmoreland, Yorkshire, Derbyshire, Denbigh, Bedfordshire, Gloucestershire, Oxfordshire, Middlesex, Surrey, Kent, Sussex and Dorset. In Scotland it breeds in localities suited to it, especially from Perthshire northwards to Sutherlandshire and Caithness. In Ireland its principal breeding-places are 
in counties Antrim, Down, Wicklow and Waterford. Outside the British Islands the Siskin has an enormous range, extending across Europe and Asia to Japan. It may be said to breed throughout the pine region of this vast area ; in winter visiting more southern and less elevated regions of the Mediterranean countries (including North-west Africa), South China and Japan. Its Siberian limits are by no means yet clearly defined.

It is quite possible that the individual Siskins which breed in the British Islands never leave them, and that the birds of this species spread generally over the English counties, and elsewhere, during autumn and winter are migrants from the Continent, either visiting our area for the cold months or passing across it to more southern localities. The habits of this bird very closely resemble those of the preceding species. In autumn and winter it assembles into flocks which wander about, often associated with Tits and Redpoles, in quest of food. They are by no means shy birds; and it is a pretty sight to watch a restless party of them amongst the alder trees, now bare of leaves, and rendering observation an easy task. During this ceaseless quest the birds are incessantly twittering to each other (possibly for the purpose of keeping the flock together) as they flit about in the branches and hurry from tree to tree, throwing thenselves into a variety of attitudes in their efforts to obtain the seeds at the 


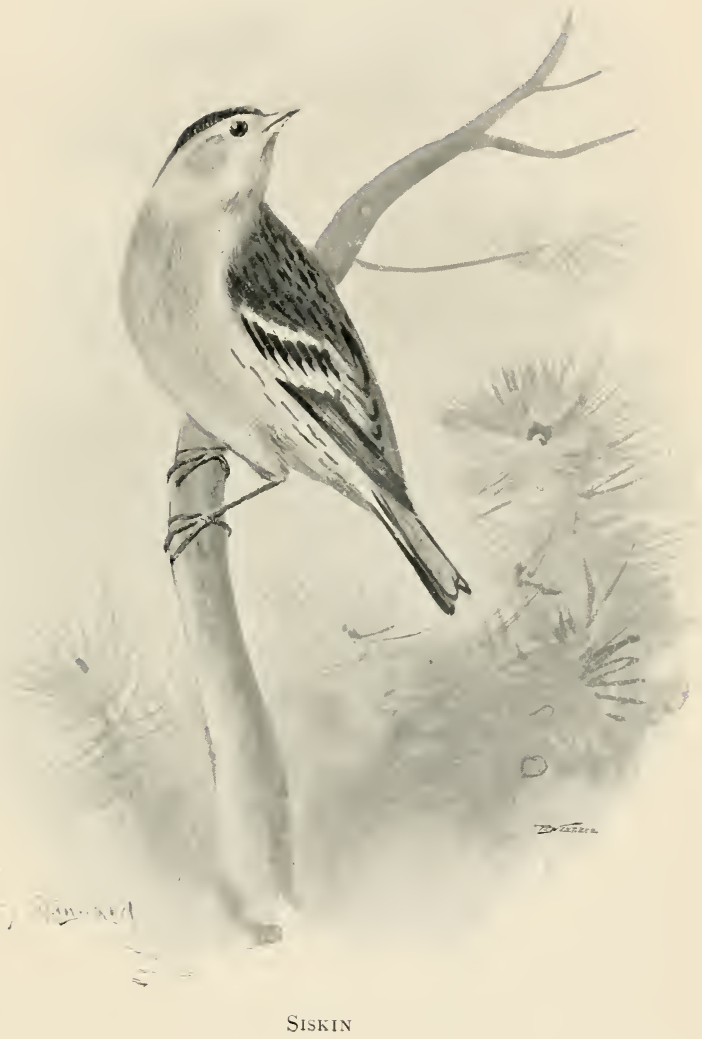





extremity of slender twigs. In autumn these flocks are often very tame; we have sometimes experienced difficulty in getting sufficiently far away to shoot them nicely enough for preserving-they appear to be as little fearful of man as Tits or Goldcrests. Great numbers of Siskins still continue to be caught in nets, but if the practice continues to the same extent much longer there can scarcely be a doubt that the bird will sensibly decrease in numbers. Some years, we may remark, it is much more abundant than others, and this fact was long ago remarked by Gätke at Heligoland. Indeed he records one migration of the Siskin in perfectly astonishing and unprecedented numbers during the autumn of 1880 , on the $I 7$ th of September of that year, giving their numbers at hundreds of thousands, in flocks like clouds, and the whole island covered with them.

The flocks of Siskins disband in early spring or disappear from English haunts as the birds return to continental nesting-grounds in the east and north. About this time the song of the male is a welcome feature in the life of our northern pine woods. The first time we heard the song of the Siskin to anything like advantage was in a Scotch pine forest between Blair Athol and Struan, and the station-master at the latter place informed us that the bird was common enough in the district. The song is a musical twittering one, very quickly uttered, melodious if not very varied. It is said that the Siskin 
sings all the year round, except during the moulting season. This may be a fact with birds in captivity, but we do not think the Siskin is a perennial songster in a state of nature. Flocks may be heard repeatedly in winter twittering very melodiously on the tree-tops, but this is concerted music, and quite different from the love-song which we believe is entirely confined to the breeding season. Another fact about the song of the Siskin of special interest is that it is often produced whilst the bird is in flight. These song-flights are very similar to those indulged in by Pipits. The Siskin is a persistent singer, and keeps in excellent voice until the breeding season is well-nigh over.

The Siskin is comparatively an early breeder, rearing two broods in the year, usually between April and July. Its nesting haunts are chiefly in fir woods and plantations; birch and gorse-coverts are said to be frequented by this Finch for breeding purposes, but this must be very exceptional. The bird appears to pair annually, although certain localities are visited very regularly for reproductive purposes. The nest is made either in the fork of a horizontal branch, or in a crotch near the top of the tree, where it is most difficult to find, owing to the density of surrounding foliage and its small size. The nest is made of fine twigs, dry grass stems and roots, and lined with moss, finer roots, vegetable down, hair, and occasionally feathers. It is placed 


at varying heights from the ground, sometimes not more than twenty feet, at others three times that distance, and, as we have already inferred, generally, if not invariably, in a coniferous tree. The eggs are five or six in number, very pale bluish-green in ground-colour, spotted and speckled chiefly over the broader half with dark reddish-brown, paler brown and grey: occasionally a few scratches or lines of darker brown are seen. Like most Finches, the Siskin is secretive and retiring during the breeding season, and seldom betrays the whereabouts of the nest by any demonstrative action.

The food of the Siskin is chiefly composed of small seeds, but in summer insects to a large extent replace this diet, whilst the young appear to be reared at first exclusively on aphides and other minute insects, as is the case with the better-known Sparrow. The call-note of the Siskin is a shrill twitter, whilst that between the sexes has been described as tsyzing - hence the bird's German name, "Zeisig."

The adult male Siskin has the head and throat black, the remainder of the upper parts yellowishgreen, shading into brighter yellow on the rump, streaked with dusky brownish-black; the wings are nearly black, the quills having yellow margins and bases, and the coverts yellow tips; the central tail feathers are dull black, the remainder black at their extremity, yellow at the base and on the inner webs. 
The sides of the head are olive-green; there is a distinct yellow stripe above and behind each eye; the remainder of the under parts below the throat is white, shading into yellow on the flanks, which are streaked with black. The female is much duller in colour than the male, wanting the black on the head and throat, and is more streaked on the under parts. The nestling is even more dingy, and the streaks on the under surface more prominent. The length of the Siskin is about four and a half inches. 


\section{THE CHAFFINCH}

Fringilla CELEBS

THE Chaffinch, we are glad to say, is not only one of the handsomest but one of the commonest of our native birds. It is widely and generally distributed throughout the British Islands, but of course most frequent in the well-cultivated and wooded districts. Its distribution extends to some of the Outer Hebrides, and during winter to the Shetlands. Outside the British limits the Chaffinch is found over most parts of Europe, reaching about as far north as the Arctic Circle in the west, but not beyond lat. $62^{\circ}$ in the Ural. South of the Mediterranean it is a resident in Algeria and probably Tunis, but is a winter visitor only to Egypt. Eastwards. it is found as a breeding species in Palestine, Asia Minor, and Western Persia, and as a winter visitor to North-west Turkestan; beyond these limits northwards it is difficult to trace, but it is doubtless found in the valley of the Obi. There are several allied species, somewhat closely resemb- 
ling the European Chaffinch, in North Africa and the various islands in the Atlantic off the coast.

Large flocks of Chaffinches visit the British Islands from the Continent in autumn, and swell the number of our resident birds; or even visit districts where the species is not found during the summer, as on the Shetlands. The Chaffinch is almost as familiar a bird as the House Sparrow or the Robin, and its attractive colours and lively cheerful ways endear it to most of us. It may be met with everywhere, due -allowance being made for season. No bird, but the Sparrow, is more common on the country highways and hedges; it is also one of the most abundant species found in the lanes, large gardens, orchards and shrubberies; it shares the open fields with Buntings, Linnets, and other Finches; whilst in winter-time it is a "familiar personality" in farm-yards, on and about ricks and manure-heaps, and even visits our very doors and windows to pick up anything suited to its tastes. Like so many other of our native Finches, the present species to a large extent becomes gregarious at the approach of winter. To a certain, extent the sexes appear to separate at this season; but this is confined almost if not entirely to the migratory individuals, for as far as our own observations extend, the resident Chaffinches of both sexes may be seen in company at all times during autumn and winter. Vast flocks of these migratory Chaffinches visit 


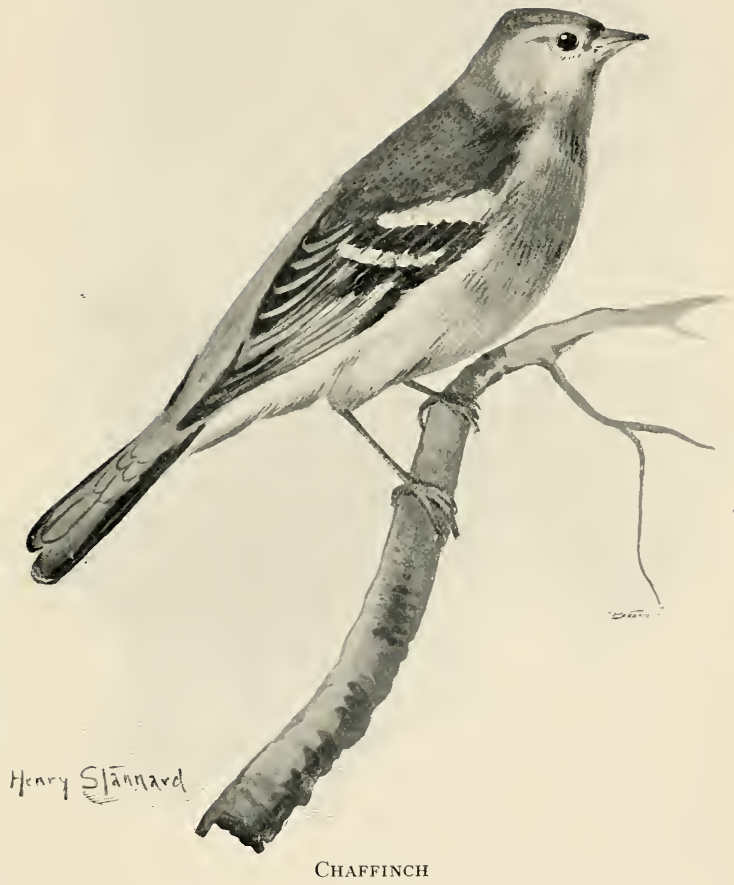





beech woods in November to feed upon the mast; the earlier arrivals are mostly males; these are followed later by flocks of females, after which the sexes mix indiscriminately. Chaffinches frequent the fields in winter-time, especially where weeds are common or where manure has been lately spread. After spending the entire day, mostly upon the ground, they resort at sunset to the nearest shrubberies to roost, often mixing with Bramblings and Redwings. Very pretty the cock-birds look when running about the bare roads in an ambling kind of way, or when flying before us with the white patches in the wings and tail glistening in the sunlight.

The Chaffinch is one of our earliest songsters in spring-one of the very first to tell us of the dim approach of a more genial season. In South Devonshire this species regains its cheery song the first week in February, but this event is quite a month later in Yorkshire. For the first few weeks after the Chaffinch regains his voice, his loud melody is the most characteristic short song of the season. It is heard everywhere, and at intervals all day long. Though a short and even monotonous song, there is a freshness and vigour about it, a heartlifting earnestness about the notes, not reached by many other birds. All the bird's vitality seems to be converted into music, all his joyousness expressed in song. Although the Chaffinch's melody may 
not secm so prominent in the later spring months, when so many other singers urge their rival claims to notice, he continues in fine voice until the middle of July, when his song is lost in the autumnal moult. With few exceptions the bird is not heard to sing again until early the following year; so rarely does the bird sing in this interval that we always consider it an occurrence worthy of note. No bird more warmly deserves to be classed as one of our favourite songsters, for the melody of few other species indeed appeals so heartily or so genuinely to our notice. Throughout the early period of its song the Chaffinch is a most pugnacious bird; his song is a strong incentive to combat, and very frequently rival males may be seen chasing each other and fighting fiercely for the possession of the fair.

Early in spring the flocks of Chaffinches either disperse to the breeding-grounds in this country or depart for their summer quarters abroad. Although this species pairs so early in the year-in February or March-nest-building does not usually commence before April. The bird's favourite haunts at this season are gardens, orchards, hedgerows and lanes. The nest is built on almost every kind of tree or large bush; in the forks and crotches of the fruit trees, in the tall hedges or whitethorns standing alone, on the moss- and lichen-draped branches of oaks, elms, birches and alders; less frequently in a holly, a yew, or amongst ivy and other evergreens. 


This home of the Chaffinch is a wonderful structure, and made so closely to resemble its surroundings that discovery is often difficult. Much variation in the materials will be remarked in a series of nests. Moss, dry grass, roots, cobwebs, lichens, cocoons and wool are the principal materials used externally ; feathers, hair, vegetable down and wool are selected for the lining. Some nests are made outwardly almost entirely of green moss; others of moss studded and garnished with lichens, bits of paper and wood and bark, all fastened on with spiders' webs and down. The nest is beautifully felted together, wonderfully finished; and nearly a fortnight is taken up in its fabrication. The eggs are from four to six in number, pale bluish-green in ground-colour, spotted and speckled with rich purplish-brown, and often clouded with paler brown. If disturbed at the nest the old birds often become very demonstrative, keeping up a chorus of pink-pink in a very appealing way. Two or more broods are reared in the season, which lasts until July.

The food of the Chaffinch in summer is largely composed of insects and larvæ, some of the former being captured whilst the bird is on the wing. In winter grain and seeds and beech-mast are the principal fare. The alarm-note of the Chaffinch is the well-known pink; its call-note is a twittering cry rapidly repeated; whilst in the breeding season the male alone utters a sharp and clear whit or whet. 
The adult male Chaffinch has the forehead black, the crown and nape slaty-blue, the back chestnutbrown, shading into yellowish-green on the rump; the wings are dark brown, the quills margined with yellow; the median wing-coverts are white, the greater ones black, tipped with yellow, forming two bars; the tail is dark brown, the two central feathers greyer than the rest, and the outermost feathers with large white patches. The general colour of the under parts is vinous-brown, shading into nearly white on the under tail-coverts. The female is much less showy, the slate-grey is replaced by brown, and the under parts are much paler and less vinous. The nestling plumage is very similar to that of the female. The total length of this bird is about six inches. 


\section{THE BULLFINCH, GREENFINCH, AND CROSSBILL}

There are three other Finches which at least deserve passing notice before bringing our account of this group to a close. Not one of them can claim much reputation for its vocal powers; yet their simple songs, crude or rarely heard as they may be, appeal to us in some degree, for at least two of these three species are well-known and popular favourites with the lover of wild birds or the fancier of them in captivity. First of these is the showy Bullfinch (Pyrrhula europaca), a bird that is found in all suitable localities throughout the British area, although rather more local in Scotland and Ireland than it is in England. It cannot readily be confused with any other native species, and the male is easily identified by his black head, wings and tail, grey back, white rump and red under-parts. Perhaps there is no shyer singer in our island, or one so readily silenced at the least disturbance. The Bullfinch is a bird of the hedges, the shrubberies and the orchards and gardens; a secretive species, 
but one easily seen, even at a long distance, by the gleaming white rump. It is very fond of flitting in drooping flight before the observer, along the hedgeside, in short stages, and is a restless active species. Its "song" is heard fitfully in spring-time, and ceases for the year almost as soon as the first set of eggs is laid. It is a soft and low little warble of short duration, and sounds like the call-note of diu strung together and uttered in a variety of tones. The Bullinch pairs for life, and in April builds a rather slovenly yet after all beautiful little nest in some thick hedge or bush. It is made externally of twigs, roots and dry grass-stems, lined with hair, and occasionally a few feathers or a scrap or two of wool. The eggs, from four to six in number, are greenish-blue in ground-colour, spotted with dark purplish-brown, and paler pinkish-brown. During the entire breeding season this species is most shy and retiring. Its food in summer consists of insects and larvæ; at other seasons of farinaceous buds, hips, haws and other berries, and the seeds of various weeds.

Our second species, the Greenfinch (Ligurinus chloris), is a much commoner bird and more widely dispersed, found in most parts of the British Islands, even including the Orkneys. It is also found throughout Europe, nearly up to the Arctic Circle, and eastwards into North-west Persia and Northwest Turkestan; whilst south of the Mediterranean 




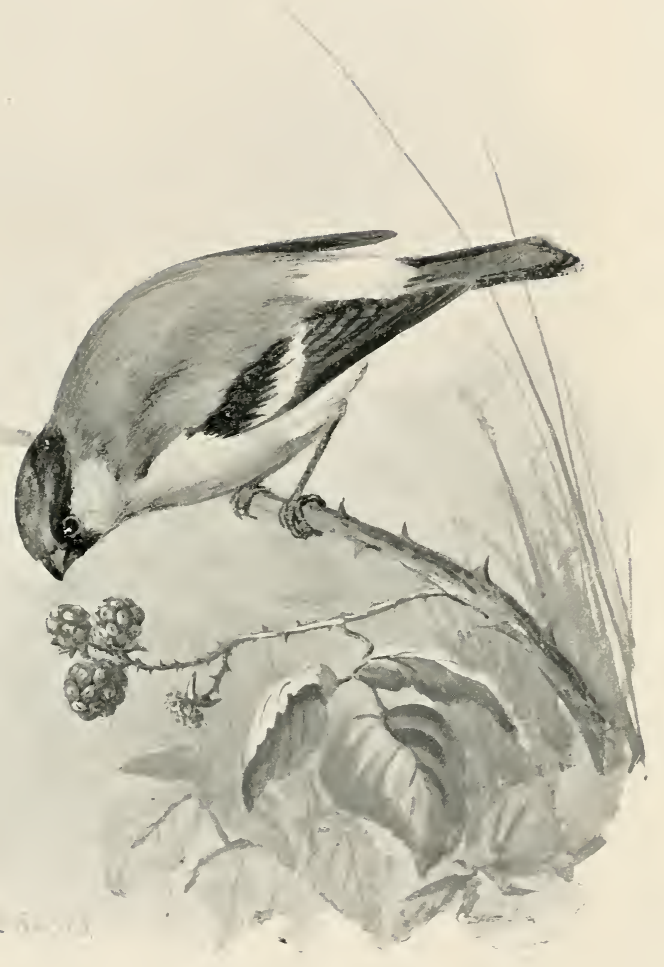

BullFinCH 

it is a common resident in North-west Africa. The Greenfinch is another handsome species, dressed in a garb of olive-green, grey, and bright yellow, the latter colour on the wings and tail showing very conspicuously during flight. Its favourite haunts are in well-cultivated districts, in orchards, gardens, shrubberies, and hedgerows. It is a resident in our islands, but increased in numbers in autumn by arrivals from the Continent. At this season it is gregarious; indeed from the late summer onwards through the autumn and winter, it may be seen in flocks of varying size, which frequent grain-fields, stubbles, and weedy pastures. Even in the breeding season it is a social bird, and several nests may often be found close together. The twittering song begins in April, and is heard to best advantage when several cocks warble in concert, as they often do in spring, and again to some extent in autumn. The ordinary call-note is a shrill twit or zit, rapidly repeated, whilst the cry between the sexes is a harsh and prolonged pee-zh. The breeding season of the Greenfinch begins in April, and as several broods are reared, is continued until August. The favourite site for the nest is in an evergreen or a dense hedge-row; but sometimes it is amongst ivy, or high up in elm and other trees. This nest is made of dry grass, twigs, moss, and sometimes wool, externally, and lined with hair, wool and feathers. The eggs, five or six in number, are white, or 
white tinged with blue or green, in ground-colour spotted and blotched with purplish-red and grey. The Greenfinch is seclusive and shy during the nesting season. The note of the hen-bird at the nest is a gentle pl-wee-et. The food of this bird is largely composed of grain and seeds, buds and berries, but in summer insects and larvæ are sought. We have remarked the fondness of this bird for seeds of the sunflower, in September and October.

Our third species is a very local one, somewhat inaptly named the "Common" Crossbill (Loxia curvirostra). This peculiar bird, one of the showiest of our indigenous species, is met with in the southern districts chiefly as a winter visitor, although its nest has been found in a great many English counties. North of the Border it becomes commoner, and breeds in the pine districts; as it also does in those of Ireland. Its extra British range is a very wide one and extends over the pine regions of Europe, Asia, and North America. Although the young bird and the female might be confused casually with the Greenfinch, the cock in his splendid vermilion or scarlet dress is readily identified. The Crossbill may also be recognized by having the mandibles crossed at the point, although this feature is absent in very young birds. In winter-time Crossbills in wandering bands may be met with in almost any kind of wooded country, but in summer they are chiefly confined to the belts of 


coniferous trees, amongst which they nest. They are lively, restless birds. Early in the spring, even before spring has come, the cock-birds may be heard uttering in a low tone their short, twittering, yet sweet little song; a performance in which the hen-birds sometimes join. The call-note is a loud and oft-repeated si-si-si; whilst the call between the sexes is a single and prolonged note, somewhat resembling that of the preceding species. The Crossbill is one of the earliest British birds to breed, and its nest may be found from February onwards to April. One brood only is reared in the season, and the bird may probably pair for life. The favourite nesting site is a Scotch fir, sometimes in a crotch near the trunk, sometimes on a flat branch near the extremity, and at heights of from a few feet to fifty feet above the ground. The nest is very similar to that of a Greenfinch or Bullfinch. The eggs are usually four, sometimes five in number, and so closely resemble those of the Greenfinch that a second description is unnecessary here. The food of the Crossbill is composed of insects to some extent in summer, but fir-cones, buds, berries, and pips of apples and pears form the greater part. 

THE SWALLOWS 





\section{THE SWALLOWS}

The Swallows comprise a homogeneous group or family, and one that so far as is at present known is not very closely allied to any other assemblage of birds. Their homogeneity is asserted not only by peculiarities in their pterylosis (or the pattern in which the feathers are arranged on the body), but by their wide flat bill, small legs and feet, and long pointed wings containing nine primaries only, which are further characterized by the tertials not reaching beyond the middle of the wing. There are upwards of a hundred species in the present family. The Swallows are unquestionably an InterTropical group, extending chiefly as migrants into the more temperate regions of both northern and southern hemispheres. The Swallows, although not generally speaking a brilliantly coloured group, are somewhat showy, the plumage of many species glowing with metallic sheen, whilst others are remarkably beautiful. These birds are songsters of very unequal merit, some species being poor vocalists, 
others of much higher musical attainment. One of the best songsters in the entire group, perhaps, is a summer visitor to our country. A peculiarity about the song in the present group is the fact that it is uttered very frequently, indeed one may say habitually, during flight. There is little variety in the songs of the Swallows; in most if not in all species it is a rather low twittering refrain, and continued for very varying periods. Of the extra British species which sing notably may be mentioned the White-rumped Swallow (Tachycineta leucorrhoa) of South America, which has a low musical and twittering refrain, often uttered as the bird is at rest on some tree or building. 


\section{THE SWALLOW}

\section{HIRUNDO RUSTICA}

Tire Swallow is more familiar as a welcome herald of the spring than as a songster, although, as we shall shortly learn, his musical powers are by no means the least part of his attractiveness. Few birds are more widely distributed than this species, and we find it in all localities suited to its requirements throughout the British Islands. It even visits such remote districts as the Hebrides and St. Kilda, the Orkneys and the Shetlands, although it may not habitually breed in them. Outside Britain its summer range is equally extended, for we find the bird at that season almost universally dispersed over Europe, nearly up to or in some parts even beyond the Arctic Circle. It also visits Siberia, at least as far east as the valley of the Yenesay, and breeds regularly in Arabia, Asia Minor, Persia, Afghanistan, Turkestan and North India (Himalayas), whilst in the district of Calcutta it is said to be a resident. The winter range includes India and Africa, but in 
the latter continent is not yet accurately defined, and certainly does not reach beyond the Tropics, perhaps not beyond the Equator. It also breeds in Algeria and the other parts of North Africa, which may include a portion of its winter range on that continent.

The Swallow reaches the more southern parts of the British Islands about the second or third week in April, but not before the beginning of May the more remote northern districts. A bird so familiar as the Swallow requires no introductory description. It is the one British species of this family that combines a uniform metallic blue-black upper parts with acutely elongated outermost tail feathers. Its favourite haunts are in the vicinity of our dwellings, sometimes in large towns; and during the entire period of its stay upon our shores it may be remarked in their vicinity. Most of its active life is passed upon the wing, in ceaseless quest of the minute insects on which it feeds, and as an example of avine flight its aerial performance is almost unsurpassed, not only for endurance, but for speed and variety of evolution. Swallows are everywhere welcomed and protected, their familiarity and complete harmlessness appealing to the least sentimental of us, and winning an immunity from harm which few other birds enjoy. The actions of this bird are too well known to need much detailed description here. Every reader must have watched the birds in their rapid flight, skimming over the meadows or the water, up and down 


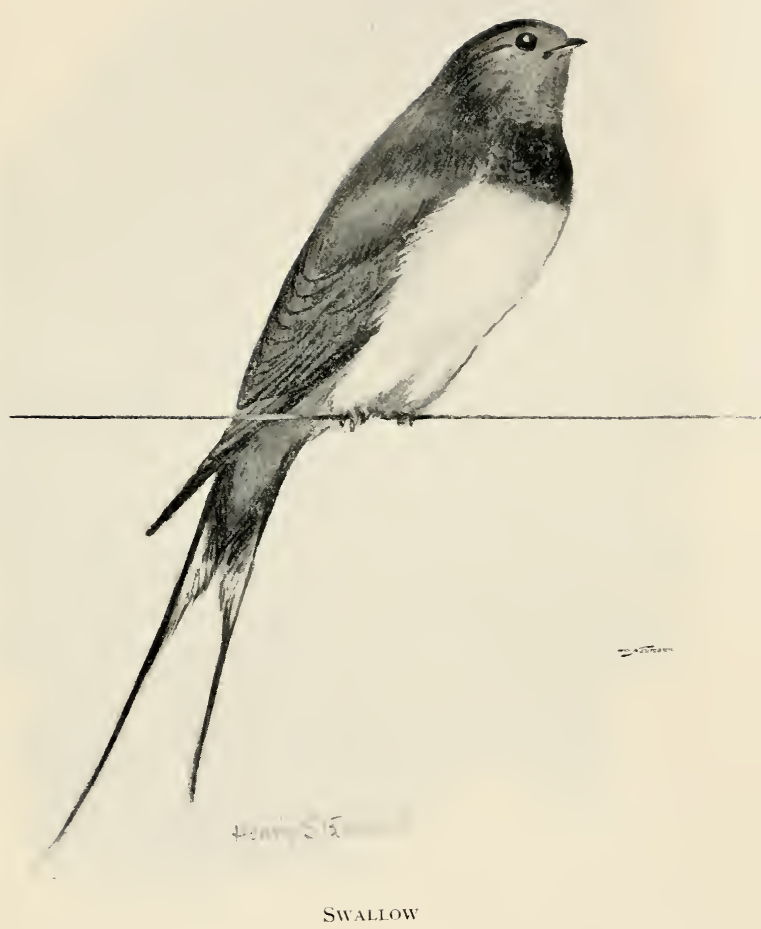





along the country highways, over the house-tops and the hedges and trees, or circling in higher flight in the air far overhead; threading their way amongst the feeding cattle, or down the narrow lanes of the country villages; now just along the grass and flowers; now striking the water as they dip to drink or to catch the insects, or with an upward soar into the higher atmosphere; then back to earth again, or to the roof of an outbuilding, a dead branch, or a telegraph-wire to rest a moment, alighting with rapidly moving wings until firmly seated. Another very attractive fact connected with the Swallow is its habit of returning year after year to the old accustomed haunts; faithful little wanderers that remain true to their old home notwithstanding their distant wanderings to warmer lands and their months of absence.

Very soon after arriving in our islands the Swallow may be heard in song. This song is both loud and sweet, a varied warbling melody uttered not only when the bird is coursing rapidly through the air, but when it is at rest. It is a song in every way harmonizing with the restless buoyant nature of the pretty singer, and his dashing rapid flight. As likely as not the observer may suddenly hear an unfamiliar song sounding he scarce knows where, but certainly some distance away. Nearer and nearer it comes, louder and louder, until at last the flying Swallow is noticed overhead singing as he flies. The song is often continued for a minute or 
more; but the bird is by no means a persistent or a regular singer, breaking out into music at fitful intervals, and perhaps most frequently after the young are abroad, in the late summer. Another interesting fact about the Swallow's song is that many young males begin to sing very soon after they are able to fly. This song is an uneven one, much more melodious in some parts than in others, some of the notes being harsh and chattering, but these are punctuated with others of exceptional sweetness and beauty - a peculiarity of much avine music besides that of the Swallow.

The Swallow, in our opinion, pairs for life, and annually returns to the same spot to breed, although not using the same nest each season as the House Martin unquestionably does. The nest is generally made in a building of some kind-little preference seems to be manifested, as long as there are ready means of egress. Holes in trees, and rocks and caves are resorted to exceptionally, and there can be little doubt that in prehistoric ages these were the usual situations. Throughout the period of its stay with us the Swallow is more or less gregarious, and it breeds in colonies whose size is determined to a great extent by the amount of accommodation offered. The nest is usually placed upon a rafter, a stone projecting from the wall, or on any other ledge that may offer a suitable support. It is a saucershaped structure made externally of little pellets of 


mud mixed with a few bits of straw, and lined with dry grass and feathers. The eggs, from four to six in number, are pure white in ground-colour, thickly sprinkled and spotted with rich coffee-brown and lilacgrey. The Swallow is most tame at its nest, and will continue to fly in and out of the building notwithstanding our repeated visits, and to feed its young within a few feet of where we may be standing. Two broods are reared in the season, the eggs for the first being laid in May, those for the second in July. The female sits the most, and the male keeps her well supplied with focd during that period.

The food of the Swallow consists exclusively of insects. Many of these-especially of the coleopterous class-are picked up from the ground. Gnats are probably the favourite if not the principal food of the Swallow in this country. The call-note of this bird is a loud whet, sometimes rapidly repeated during moments of excitement. After the breeding season, Swallows congregate in vast numbers at certain well-recognized spots previous to their departure south. By far the greater number leave us in October, but it is no uncommon thing to see odd birds in November, whilst they have been recorded exceptionally in the three following months. Regarding the presumptive hibernation of this species we may refer any interested reader to our work entitled The Migration 
of Birds, where the subject is dealt with at some length.

The adult male Swallow has the forehead and throat chestnut; the upper parts are bluish-black with a metallic gloss; the wings and tail are brown glossed with green; all but the two central tail feathers have a white spot on the inner web, which shows very distinctly when the tail is expanded during flight. The general colour of the under parts below the throat, except a pectoral band of bluishblack, is white, suffused with buff. The female closely resembles the male in colour, but the outermost tail feathers are not so long: the nestling plumage is very similar to that of the female. The total length of this bird is about seven and a half inches. 


\section{THE HOUSE-MARTIN}

\section{Chelidon URBICA}

Although the House-Martin is even a more fitful singer than the Swallow, we are loth to exclude such a pretty and familiar species. It is distinguished readily from the Swallow, even at a long distance, by the white rump and short tail. It is even more widely and generally distributed over the British Islands, breeding as far north as the Shetlands. Its extra British summer range includes most of continental Europe, in the west to the North Cape, but in the east to limits which are at present somewhat ill-defined. Eastwards it includes Asia Minor, Palestine, and Persia, but the Siberian limits beyond the Urals are again uncertain. South of the Mediterranean the summer range includes North-west Africa, but in Egypt and Nubia the bird is only known as a passing migrant. The winter range of this Martin includes North-west India and the African portion of the Inter-Tropical Realm.

The House-Martin reaches its British haunts in 
spring about the middle of April, a few days later in the north than in the south. Its haunts are very similar to those of the Swallow, but even more of a cosmopolitan nature, for the bird not only resorts to the neighbourhood of human habitations in sufficiently rural districts but to marine and inland cliffs. It is also more gregarious than the Swallow, some of its nesting colonies being very extensive. The habits of the two birds are very similar. There is the same ceaseless flight and nervous activity, the same coursing to and fro, now close to the ground, then hundreds of feet above it, gliding, fluttering, skimming here and there the livelong day on untiring wings in quest of food. There are few prettier sights than a large company of House-Martins engaged in feeding above some large sheet of water. Their flight is not quite so rapid and impetuous as that of the Swallow, but it is equally powerful and sustained. The Martins in an ever-moving throng flit to and fro in mazy course, ever and anon dipping to the water and striking the surface, now rising and falling like shuttlecocks, or chasing each other with shrill cries. Heavy rain will not deter them in their restless search for food, and into the darkening twilight their labours are often prolonged. The air is the Martin's province; and it will be remarked that when the bird alights it does so awkwardly and aided with its wings, which are kept outspread and beating until a firm hold is secured. 




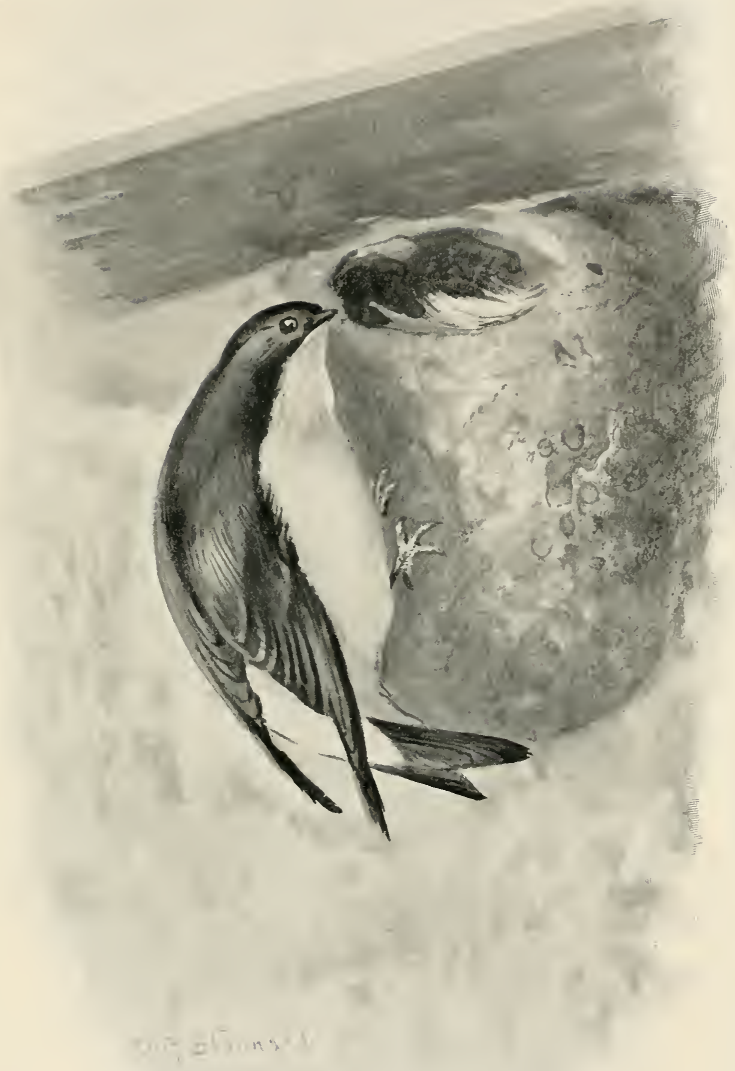

House Martin 

The bird never attempts to walk, remaining in one place until it seeks the air again. Martins are very fond of settling on roofs and telegraph-wires, especially in autumn, when the young birds are about which are not capable of such prolonged exertion as their parents. We have, at that season, seen wires so densely crowded with Martins as to look like huge cables at a distance, and perceptibly bent by the weight of the clustering birds. The HouseMartin has little fear of man; it is one of the most trustful of birds, and not only builds its nest in very much frequented places, but will flit and hover round us in a most engaging manner.

As we previously remarked the House-Martin is not a very frequent singer. Its song is fitful, uttered at unexpected moments, and far more frequently whilst the bird is sitting on a building or wire than that of the Swallow. The song is uttered in a low tone, and is certainly sweet and varied, but not quite so musical as that of the preceding species. We should estimate that the song of this Martin is heard at least ten times less frequently than that of the Swallow; and this latter bird is by no means a frequent singer. We are at a loss to account for this vocal tardiness; it may be that birds of the Swallow family work off most of their vital energy in flight, and consequently express less of it in song than other birds of more sedentary habits, noted for their persistency of musical effort. The Hous:-Martin may be heard to warble at 
intervals during the entire period of its sojourn with us; there is no special time at which the song is more prominent than others, and we always consider ourselves fortunate in hearing it.

There can be no doubt that the House-Martin pairs for life, and the old nesting-places-even the old nests-are used years in succession. We know of colonies of these species that were as busy and thriving twenty or more years ago as they are to-day. This Martin breeds almost as plentifully on cliffs as on buildings, and seems to show no special preference for either. Numbers of nests are often made side by side, or more or less in clusters. No other nest of any British species is more openly exposed, neither is any other more curious. It is variously built under eaves, in corners of windows, beneath copings and ledges of masonry, or in nooks of the cliffs-but everywhere invariably under a projection of some kind. It is shaped like half a basin, but some nests are much more semi-conical than others. Externally it is made of pellets of mud intermixed with bits of straw, arranged course after course like bricks, and commenced at the bottom. This shell is lined with dry grass and feathers. The aperture admitting the parent birds is at the top, either at the front or on one side, and is much narrower in some nests than others. The birds will form nest after nest if it is removed; and show a most unaccountable preference for certain spots. The eggs are from four to 
six in number and pure white. It is said that exceptionally the eggs are spotted with reddishbrown. Two broods are reared in the year, and the old birds are most attentive in their care of the young, bringing them food every few minutes during all the hours of daylight.

The food of the House-Martin is composed exclusively of insects, many of which are picked up on the ground or from the surface of the water. The call-note of this Martin is a shrill twit sometimes rapidly repeated. After the young are reared the birds become even more gregarious, congregating in vast flocks preparatory to departure. Their migration south begins at the end of September, and is continued during the following month. It is by no means unusual to see a few birds in South Devonshire in November, and odd examples have been noticed in December.

The Martin has the general colour of the upper parts glossy steel-blue, glossed with green and purple; the rump and some of the upper tail-coverts are white; the wings and tail are brownish-black shot with green, the tail, although sharply forked, is not so much so as in the preceding species. The under parts are white. The female resembles the male in colour; the nestling plumage is browner above, with less sheen, and the under parts are suffused with brown. The total length of this Martin is about five and a half inches. 

THE STARLINGS 





\section{THE STARLINGS}

Many of the Starlings are gifted not only with considerable musical power, but with ready aptitude for imitating various sounds, hence they are general favourites as cage-birds. The Starlings form a somewhat heterogeneous group of birds, characterized by having nine primaries in the wing, a swollen nostril, no nasal bristles, and a non-scutellated hind tarsus. The young in first plumage differ considerably in colour from their parents. They are an Old World group of wide distribution, yet absent from Australia. Of the more typical Starlings-of which our British species is a familiar example-about ten species are recognized by ornithologists. These are distributed over the Palæarctic region, and the northern parts of the Oriental region so called. The British Starling we will now proceed to consider in detail. 


\section{THE STARLING}

\section{STURNUS VULGaRIS}

The Starling is another familiar songster, found almost everywhere, and a universal favourite from its engaging ways and trustful disposition. It is a resident, and breeds in more or less abundance in all cultivated and inhabited districts of England and Wales. In Scotland it has increased enormously within the past fifty years, gradually extending its area, so that it may now be said to breed in every suitable locality, including the Hebrides, St. Kilda, the Orkneys and Shetlands. In Ireland it is common and widely dispersed, especially during winter, becoming more local in the breeding season. Its extra British range includes most parts of Europe; but in the Mediterranean countries and in Persia the bird is a winter visitor only. Further eastwards in Asia, and to some extent in the Mediterranean basin, the Starling is replaced by several closely allied forms.

The Starlings that breed in the British Islands 270 




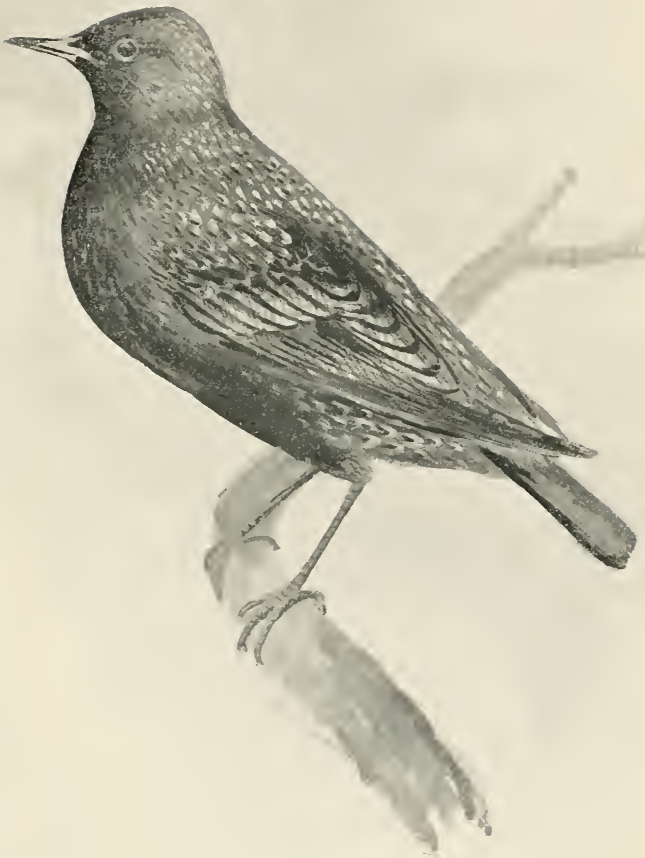

STARLING 

are very probably resident, but in autumn vast flights of this species invade our area from the Continent, sweeping across the North Sea in numbers that are literally amazing. Our sedentary population also appear to be subject to a certain amount of intern 1 migration or local movement. From the easy manner in which the Starling's ways may be observed the bird is one of our best known species. Its habits are exceptionally entertaining, whether in spring and summer when the bird is bringing up its brood near our dwellings, or in autumn and winter when it lives for the most part in large compact flocks whose movements are exceptionally regular. The Starling has a happy knack of adapting itself to circumitances, and of accommodating itself to its surroundings in a way that few other birds are capable of. Owing to this rady adaptability the bird may be met with in a vast variety of haunts, both in the vicinity of human dwellingswhether cities, villages, or scattered homesteadsor in wild and remote districts. It is difficult to say when the Starling is most interesting. In spring his lively ways and merry notes, his impudence in regard to nesting-places, and his regular habits are entertaining enough; in autumn and winter his vast gatherings, his noisy clamour when assembling at the well-known roosting-places, his wonderful aërial gyrations are none the less attractive. At all seasons the Starling is a gregarious bird, but its flocks are 
most conspicuous after the breeding season is over. A flock of Starlings are always an interesting sight, whether engaged searching for food on the fields, running hither and thither in scattered order, occasionally flying short distances; or when flushed and wheeling and gyrating in the air previous to settling again. No matter how scattered the birds may be, when disturbed they quickly bunch together into a compact mass, whose movements seem governed by a common impulse. These flocks are wonderfully regular in their movements. We remember a vast flock that used to pass over a certain spot on their way to the roosting-place every evening at twenty minutes past four, and during a whole winter this regularity was maintained, the birds passing to time with amazing punctuality. These roosting-places of the Starling are animated sights at sundown. From various points flock after flock of birds arrive and settle in the trees or osier-beds, keeping up a deafening chatter which soon becomes a perfect roar. Then, if startled, the entire throng of birds will rise in silence and perhaps ascend to a considerable height. The most wonderful part of the proceedings now begins as the mighty throng of birds spread out like a vast net, close up again, wheel to the right or left, swoop down with amazing speed as if about to settle, but rise again, repeating the manœuvre several times, until at last the vast sable host alight with the precision of drilled troops, and almost 
immediately the babel of sounds is renewed. This noisy chorus is kept up long after the birds have settled for the night; indeed all night long some of the birds are chattering and scolding. As soon as the new year opens Starlings begin to assemble at their breeding-places for a short time each day, and as the spring approaches these visits become more prolonged, the flocks disband, and the birds begin to settle down for the serious business of the season.

It is now that the song of the Starling is perhaps heard at its best. The bird might almost be classed as a perennial songster, for he warbles at intervals through the year, but he sings most industriously in spring. Taking his station upon some tree, chimney, or roof he warbles by the hour together, with little break, accompanying his song with quivering drooping wings, and every feather elevated in nervous excitement. His song is almost as varied as that of the Song Thrush, has a good deal of repetition about it, and harsh notes and sweet ones are mixed up together in most extraordinary confusion. Some of these notes are melodious, others are creaking, chattering, and harsh, but the vigorous and persistent method of their utterance goes far towards making them pleasing and acceptable to the ear. The Starling has also a curious way of introducing the music or the cries of other birds into his song. We have not another bird mimic in the country a tithe so clever as he, as a mocking-bird with us 
he must rank highest. Various sounds are also imitated one would almost think for the mere pleasure of copying them as the bird sits jauntily aloft. The Starlings here imitate to a nicety the cry of the Green Woodpecker, and so closely and cleverly is this done that we defy a person to detect the difference! Many other sounds are imitated, but this to our mind seems the most astonishing. IVe never heard the Starling utter this note in districts where the Green Woodpecker is absent, which clearly proves imitation. When the young are hatched the cock Starling has little time to indulge his musical tastes, but when the breeding season is over and the moult undergone he breaks out anew into song ; and it is no uncommon thing to hear odd birds in a large flock whistling merrily, even in midwinter.

The Starling pairs for life, and returns annually, even in spite of much disturbance, to its old nestingplace. The bird will build its nest in almost any hole it can find, either amongst cliffs, in trees, or in buildings of all kinds. In some places it will even take possession of a hole in the ground or in a stack of peat. The nest is a slovenly one, made of straws, grass, roots and other rubbish, and lined sometimes, but not very generally, with a few feathers. Very often some of the material is left hanging out of the entrance to the hole, betraying the whereabouts of the nest to every passer-by. The eggs are from 


four to seven in number, and pale greenish-blue in colour, without markings of any kind. The Starling will continue to lay egg after egg in the nest as regularly as they are removed. After the young are hatched the parents are most assiduous in supplying them with food. They are very noisy in the nest, and the arrival of the parent with food is usually the signal for a loud outburst of clamouring cries.

The food of the Starling is very varied. In all the open months the bird seeks for worms, slugs, and various insects; in the autumn it consumes berries and fruits; whilst during long-continued severe weather it will visit houses and manure-heaps to pick up anything likely to satisfy its hunger. The bird is sometimes seen hawking for insects in the air almost like a Swallow. The call-note of the Starling is a long-drawn mellow whistle, whilst its alarm-notes are almost as harsh and rapidly repeated as those of the Mistle-Thrush.

In breeding plumage the adult male Starling has the general colour of the plumage black glossed with metallic green, purple and violet; the back shows bronze reflections, the head green, the flanks purple ones; the wings and the tail are dark brown, with broad glossy black margins; the under tail-coverts have broad buff margins. The female somewhat closely resembles the male in colour, but less metallic and more spotted, and the feathers on the throat are less elongated. The nestling plumage is nearly 
uniform brown, palest on the breast and abdomen, which are streaked with darker brown. After the autumn moult much of the brilliant metallic hue is concealed by the pale tips to the feathers, which gradually abrade before the following breeding season. The total length of this bird is about eight inches. 


THE CUCKOOS 





\section{THE CUCKOOS}

The Cuckoos form a large and fairly homogeneous group, although presenting considerable diversity in size, colouration and general appearance. They are divisible into no less than six sub-families, all of which, however, possess the following characters in common: a zygodactyle foot (two toes directed forwards and two backwards), a bridged or desmognathous palate, a naked oil-gland, no after-shafts to the feathers of the body, and the tail feathers generally ten, but in two genera only eight, in number. The Cuckoos are practically cosmopolitan in their distribution. They are birds which present much variation in the style and colouration of their plumage, some being remarkably showy and of brilliant hues, others very soberly arrayed. Although the Cuckoos can make no claim to musical distinction-none of them being birds of song-their love notes are both interesting and varied. Our own Cuckoo's voice is such a popular feature in the concert of the spring, that we feel to omit all mention 
of the bird and its allies in the present volume would be an unpardonable omission. The Cuckoo's cry is in certain respects a "song," gained and lost according to season, peculiar to the male sex, and analogous in every respect to the sounds of more musical species; so that a brief notice of this bird and its allies cannot fail to prove of interest. Before proceeding to notice our British Cuckoo, mention must be made of the singular cries or "songs" of some of the foreign species. Beginning with the species of which our own Cuckoo is typical, we find a curious and interesting variation in the note they utter. For instance, the Himalayan Cuckoo (Cuculus himalayanus) utters a guttural and deepsounding hoo, very similar to the cry of the Hoopoe. This cry, which may be heard for a long distance, is repeated several times in succession. The Greyheaded Cuckoo (C.poliocephalus), of Africa, cries kowkow, kow-kow, all day long from the woods; whilst another African species, the Red-breasted Cuckoo, has a whistling note of three syllables. The Indian Cuckoo (C. micropterus) utters a startling cry rendered by some observers as bho-kusha-kho. The Great Spotted Cuckoo (Coccystes glandarius), typical of another group, sings kee-ow-kee-ow. The Golden Cuckoo (Chry'sococcyx cupreus), of tropical Africa, has a note which Layard describes as an "oft-repeated mournful cry of di-di-dididric." The Yellow-billed Cuckoo (Coccyzus americamus), of America, utters 
according to Wilson, "an uncouth guttural sound or note, resembling the syllables kowe, kowe, kowe, kowe, kowe, beginning slowly but ending so rapidly, that the notes seem to run into each other, and vice versâ." Among less familiar species we may mention the Indian Coucal (Centropus sinensis), that, like others of its class, possesses a howling cry which has been described as whoot, whoot, whoot, whoot, followed, after an interval of a few seconds, by kurook, kurook, kurook, kurook. Lastly we may mention the Cuckoos of the genus Crotophaga of Tropical America, which repeat with irritating persistence the double cry of tee-ho. 


\section{THE CUCKOO}

\section{CUCULUS CANORUS}

Although there can be no doubt that the Cuckoo is far more often heard than seen, and even less frequently identified when actually observed, it is a universal favourite. Its distinctive note, so characteristic of our English spring, is the secret of its popularity. We may not see the mysterious stranger, which seems to bear spring northwards upon its wings, but there is no missing the fascinating cry. The Cuckoo, again, confines himself to no particular area or locality, and this universal distribution over the country is another reason for the estimation in which he is popularly held. The Cuckoo is dispersed throughout the British Islands, even extending to most of the Hebrides, to the Orkneys and the Shetlands. Outside the British limits the Cuckoo is a bird of very wide range, inhabiting the entire Palæarctic region duing summer, from the Atlan ic to the Pacific, and as far north as the limits of forest growth. It breeds 


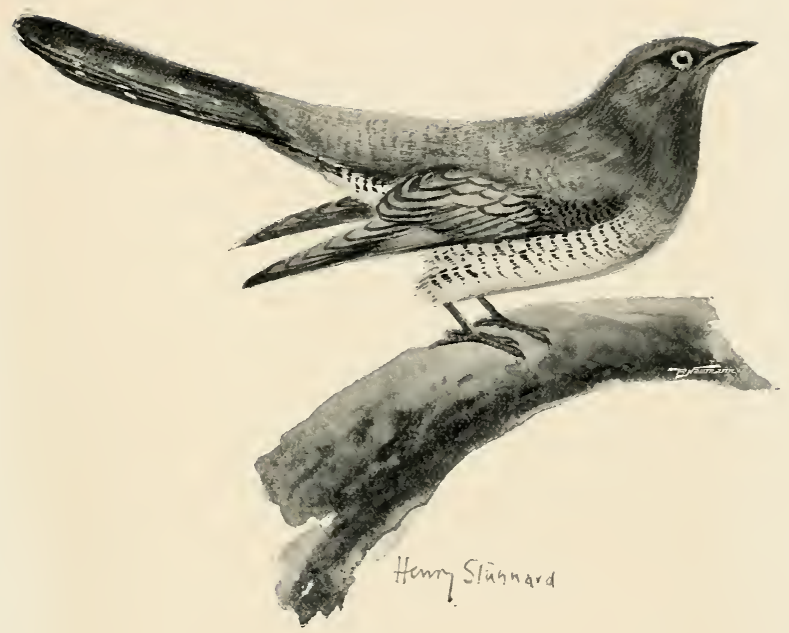

Cuckno 



throughout Europe, passing through North Africa chiefly on migration, but a few remain to breed. In Asia it is a summer visitor to Palestine, Asia Minor, Persia, Afghanistan, Turkestan, Siberia, the Himalayas, Mongolia, China, and Japan. Its winter range includes the African portion of the Inter-Tropical Realm, India, and Malaysia.

The Cuckoo generally arrives in the British Islands about the middle of April, that is to say in the southern districts, for the bird is at least a fortnight later in the northern ones. The males precede the females by a few days. As we previously remarked, this species may be met with almost everywhere, in cultivated districts as well as upon the open moors and even the mountain-tops, bare country as well as woodlands, inland as well as littoral localities. Its ubiquitousness is equalled by few other birds. At all times of its stay upon our shores we should be disposed to describe the Cuckoo as a somewhat shy and retiring species. It loves to sit amongst the foliage, at intervals flying across the open country from one tree or plantation to another, in a direct unwavering manner, with tail straight out and wings somewhat rapidly and very regularly beating. Sometimes, however, it may be noticed to turn and twist about in an erratic way, or swoop Hawk-like towards the ground, then soar upwards into the nearest tree. As most readers may be aware, small birds persistently mob this 
species, and it is usually attended during flight by one or more of these teasing satellites. The Cuckoo appears also to be much attached to its haunts, returning to them each season, and what is more, wandering little from them during the entire period of its stay. This bird is not often seen upon the ground, except about the time the eggs are being laid; it is a clumsy "alker owing to its remarkably short legs; neither does it seem to climb about the branches as its zygodactyle foot might suggest; it hops from twig to twig, however, with ease, though not given to much movement, when once it has perched.

A few days after their arrival the males begin to " sing." It is probable that the song is not regained until the arrival of the females leads to rivalry amongst the males. The Cuckoo's note is all too well known to need much description here, the full rich double cry of cuck-koo being familiar to most readers. It may, however, be remarked that this song, as the period of its cessation approaches, becomes much less clear, and is then frequently prolonged into three syllables. Very exceptionally the song takes the form of three notes in spring, but then it will be remarked that the last syllable-the koo-is the one repeated, and not the first, which is a sign of decadence only. This song is entirely confined to the male bird, and is continued for about two months. "he bird is a most persistent singer, often remaining 


for a long time upon one particular perch, calling at intervals, so long as it is undisturbed. This song is also heard from time to time as the bird is flying, generally when ahout to alight, as we are reminded in the old couplet :

"The Cuckoo is a merry bird, He sings as he flies."

The bird sings early and late. The female too utters a very peculiar and characteristic cry, a bubbling note impossible to express in words. Besides these notes, Cuckoos of both sexes utter a chattering kind of cry, especially when excited.

The parasitic habits of the Cuckoo are known to most readers. It is impossible to enter here very fully into what is a very intricate subject: our entire volume might be occupied with this portion of the bird's economy alone. It will be sufficient here for our purpose to say that the female Cuckoo soon after her arrival, and often in more or less close concert with a male, seeks out the nest of some small insectivorous bird and inserts her egg, leaving it to be incubated and the young tended by the birds she has so curiously duped. The egg appears first to be laid upon the ground, and then carried in the mouth until a suitable nest is reached into which it can be gently dropped. Cuckoo's eggs have been found in the nests of a great number of species (some of them totally 
unfitted for the purpose), but in our islands the nests of the Hedge Accentor, the Meadow Pipit, and the Reed Warbler seem to be the favourites. Less frequently a Pied Wagtail, a Wren, a Finch, or a Bunting is selected for the rôle of foster parent. It is difficult to say exactly how many eggs each individual female lays during the season; we provisionally suggested from five to eight, but possibly this number will have to be increased. The eggs of the Cuckoo vary considerably in colour, and present several well-marked types, the females producing each type seeking as far as possible to insert them in nests where the eggs show similarity in colour. The usual ground-colour varies from greyish-white to greenish-white, spotted, blotched, and freckled with various shades of olive-brown or reddish-brown, intermingled with minute specks of very dark brown. Some eggs closely resemble those of the Sky-Lark, others those of a Wagtail, a Reed Warbler, or a Meadow Pipit; whilst there is a blue and spotless variety known similar to that of the Redstart. $\mathrm{W}$ e ought also to say that the young Cuckoo (or the foster parents) ejects the other nestlings, but the precise age or time at which this is done is by no means clear. We would refer the reader to our work Jottings about Birds for fuller information.

The food of the Cuckoo is principally composed of caterpillars, especially such as are covered 


with hairs; the bird also eats beetles, lepidopterous insects, and larvæ. The food of the young depends very much upon the species that rears it. The Cuckoo is an early bird to depart south. The return migration begins in August, most of the old birds apparently leaving before the young, but in this, as in so much else concerning this species, more definite information is sadly wanted.

The general colour of the upper parts of the adult Cuckoo is slate-grey, suffused with brown on the wings, and becoming nearly black on the tail; the quills are barred with white on the inner webs, and the tail feathers are tipped with white, and show traces of white bars. The under parts are greyish barred with dusky-brown below the breast. The female closely resembles the male in colour. The nestling plumage is barred with brown and tipped with white above and below. The total length of this bird is about fourteen inches. 


$$
5760+22^{2}
$$










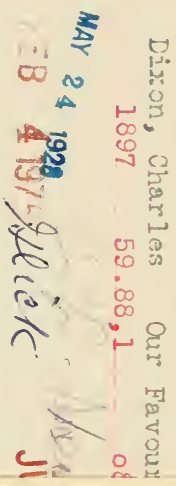


